\title{
CICLOESTRATIGRAFIA DO EOPERMIANO - ESTUDO DE CASO NO GRUPO ITARARÉ, BACIA DO PARANÁ (PARTE 2): EVIDÊNCIAS DE INDUÇÃO ASTRONÔMICA (ORBITAL E SOLAR) NO CLIMA E NA SEDIMENTACÇÃO
}

\author{
JOSÉ GUILHERME RODRIGUES DA SILVA', NILO CHAGAS DE AZAMBUJA FILHO²
}

\begin{abstract}
CYCLOSTRATIGRAPHY OF LOWER PERMIAN - CASE STUDY IN ITARARÉ GROUP, PARANÁ BASIN (PART II): EVIDENCES OF ASTRONOMIC FORCING (ORBITAL AND SOLAR) IN CLIMATE AND SEDIMENTATION - The existence and nature of possible astronomic forcing of cyclicity in glacial sediments of the Itararé Group, Paraná Basin, during the Eopermian, were studied in core and gamma ray log data from two wells drilled by CPRM (Companhia de Pesquisa de Recursos Minerais) to coal research, one in Santa Catarina and other in Rio Grande do Sul. The distance between the original location of the cores (about 380 $\mathrm{km}$ ) made it possible to test the astronomic forcing in this deposits in different locations of the basin. Two methods of data sampling were used, according to data scale and the possible forcing: the gamma ray logs were digitized and sampled at $1 \mathrm{~cm}$ intervals, in order to test the presence of orbital forcing (20,000 to 400,000 years) or other forcing phenomena (3,000 to 10,000 years), and the cores were scanned in the intervals with rhythmites and transformed in gray scale data sampled equally $(0,2538 \mathrm{~mm})$, in order to search for annual to centennial cycles. The harmonic analysis showed cyclicity in both scales: orbital cycles ranging from about 17,000 to 100,000 years and solar cycles ranging from about 22 to 1,000 years. The accumulation time calculated for one well in log and core data (about 9,400 years for the scanned interval and about 12,600 years for the same interval in log data) showed a very high correlation. The accumulation rates calculated for the $\log$ data, ranging from 5,2 to $9,3 \mathrm{~cm} / \mathrm{ka}$, are very similar to the Pleistocene ones. The analysis also showed that the complete sedimentary record of the Itararé Group for one of the wells corresponds to about half precession cycle (12,342 years). As both astronomic forcing phenomena detected, the solar and the orbital cycles, affect climate on a global scale, certainly their influence on sedimentation occurred in other locations of the basin.
\end{abstract}

Keywords: cyclostratigraphy, Itararé Group, Lower Permian.

\begin{abstract}
Resumo A indução astronômica no clima da região da Bacia do Paraná, durante o Eopermiano, foi testada com o intuito de determinar a natureza da ciclicidade presente em sedimentos do Grupo Itararé, de origem glacial. Utilizaram-se dados de testemunhos e de perfis de raios gama de dois poços, um em Santa Catarina e outro no Rio Grande do Sul, perfurados pela CPRM. A distância entre as locações dos poços (cerca de $380 \mathrm{~km}$ ) possibilitou testar a influência da indução astronômica em localidades distintas. Dois métodos de amostragem foram utilizados, de acordo com a escala dos dados e com a possível indução: perfis de raios gama foram digitalizados e amostrados em intervalos de $1 \mathrm{~cm}$, para testar a presença dos ciclos orbitais na escala de 20 mil a 400 mil anos, ou fenômenos indutores na escala de 3 mil a 10 mil anos, e os testemunhos foram escaneados nos intervalos com ritmitos e transformados em dados em escala de cinza equiespaçados $(0,2538 \mathrm{~mm})$, objetivando a busca por ciclos anuais a centenários. A análise cicloestratigráfica sugere a presença dos ciclos orbitais, com períodos de cerca de 17 mil a 100 mil anos, caracterizados em perfil, e dos ciclos solares, com períodos de cerca de 22 a 1000 anos, evidenciados nos testemunhos. Os tempos de acumulação calculados mostraram um alto grau de correlação (cerca de 9400 anos para um intervalo escaneado e de 12600 para o mesmo intervalo nos dados de perfil). As taxas de acumulação calculadas para os perfis variam entre 5,2 a $9,3 \mathrm{~cm} / \mathrm{ka}$, muito similares àquelas do Pleistoceno. A análise mostrou ainda que a seção completa do Grupo Itararé em um dos poços corresponde apenas à cerca de meio ciclo de precessão (12342 anos). Como os ciclos solares e os orbitais afetam o clima de maneira global, certamente influenciaram a sedimentação em outros pontos da bacia.
\end{abstract}

Palavras chave: cicloestratigrafia, Grupo Itararé, Eopermiano.

INTRODUÇ̃̃o O papel principal da cicloestratigrafia tem sido definir se os ciclos orbitais terrestres têm ou não capacidade de deixar sua impressão nos sedimentos e se essa impressão pode ser separada tanto dos ciclos e oscilações gerados de forma aleatória quanto das feições sobrepostas pela diagênese. Como ciclos orbitais compreendem-se desde o ciclo diário, responsável pelos dias e noites, até os ciclos de oscilação e revolução do Sistema Solar na galáxia (Einsele et alii 1991, House 1995). A influência dessa indução orbital nas mudanças cíclicas climáticas e, através delas, na sedimentação, há muito tem sido estudada. Os objetos principais desses estudos têm sido os ciclos orbitais, mais conhecidos como de Milankovitch. Além desses, outros ciclos não orbitais, porém também astronômicos, os solares, têm ganhado atenção cada vez maior dos geocientistas, devido à alta recorrência nos registros sedimentares. Esse artigo é o resultado do estudo desses dois fenômenos indutores, da sua influência nas oscilações e variações cíclicas climáticas e dos efeitos das últimas na sedimentação durante o Eopermiano na Bacia do Paraná (Silva 2001). A metodologia de aquisição dos dados para o estudo foi descrita em outro trabalho, denominado "Cicloestratigrafia do Eopermiano - Estudo de caso na Bacia do Paraná (Parte I): uma metodologia pra preparação de dados de perfil e rocha" (a partir deste ponto, CEGI-1), presente nesta mesma publicação.

Ao contrário dos ciclos orbitais, a influência dos ciclos solares no clima e na sedimentação, apesar de cada vez mais documentada na literatura (Anderson 1961, Eddy 1976, Williams 1985, Williams \& Sonett 1985, Halfman \& Johnson 1988, Fortes 1990, Ripepe \& Fischer 1991, Fortes 1992, Anderson 1992, Schaaf \& Thurow 1994 e 1997, Lundqvist 1998, Von Rad et al. 1999), ainda não está bem estabelecida e é alvo de controvérsias (Williams 1989, Gallet et al. 2005). Os geocientistas estão mais acostumados a trabalhar com processos de sedimentação de depósitos de maré e de varves, relacionados

1 - PETROBRAS - E\&P Exploração e Produção - UN-Bacia do Espírito Santo - Av. Fernando Ferrari, 845 UFES - Goiabeiras - 29060-973 - Vitória, ES, Brasil - jguilherme@petrobras.com.br

2- PETROBRAS - Centro de Pesquisas e Desenvolvimento - Av Jequitibá, 950 - Cidade Universitária - Ilha do Fundão - 21941-598 - Rio de Janeiro, RJ, Brasi1 niloazambuja@petrobras.com.br 
a induções astronômicas cíclicas nas escalas de um mês a um ano, passando em seguida para a escala dos ciclos orbitais, da ordem de 10 mil a 400 mil anos (estes sendo os mais comuns. Existem também ciclos da ordem de 1,3 a 2 milhões de anos). A escala intermediária, ligada aos ciclos solares, não é ainda muito familiar. Um dos motivos é que o mecanismo físico através do qual esses ciclos provocam mudanças climáticas ainda é palco de muitos debates na comunidade científica (Dicke 1979, Bucha 1988, Bucha 1991, Bucha \& Bucha 1998, Anderson 1992, Gallet et al. 2005).

Segundo Einsele et al. (1991), o efeito mais característico de alguns processos sedimentares induzidos pelos ciclos astronômicos é sua simultaneidade e similaridade de atuação para diferentes bacias, tornando possivel correlacionar parte das seqüências sedimentares por longas distâncias, até mesmo de uma bacia para outra. A proposta deste estudo foi testar a possibilidade de indução astronômica cíclica no clima do Eopermiano e, por conseqüência, na deposição dos sedimentos que deram origem às rochas do Grupo Itararé. Em caso positivo, tentar caracterizar quais tipos de mecanismos foram responsáveis pela indução e obter um detalhamento estratigráfico de alta resolução para as seções estudadas.

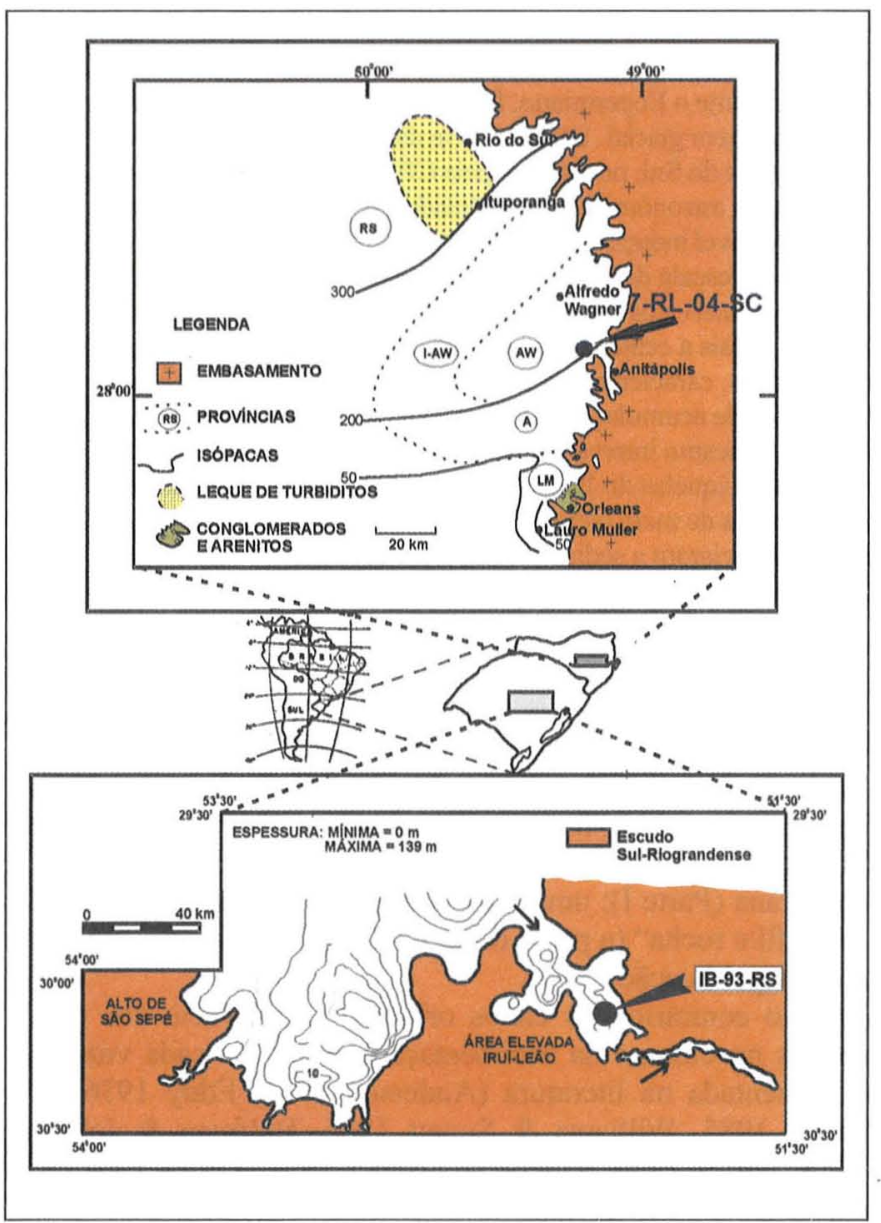

Figura 1 - Mapas de localização e de isópacas. Mapa superior: contexto geológico do testemunho 7-RL-04-SC, na unidade superior do Grupo Itararé, em Santa Catarina, segundo Castro (1991), e as províncias definidas por esse autor: $R S=$ Rio do Sul; $I$-AW=Ituporanga-Alfredo Wagner; $A=$ Anitápolis; $A W=$ Alfredo Wagner; LM=Lauro Miller: Mapa inferior: região dos paleovales de Capané, Leão e Leão-Mariana Pimentel, preenchidos por rochas do Grupo Itararé (Lopes 1995). O poço IB-93-RS está inserido no contexto geológico do paleovale Leão.
Para esse propósito foram escolhidos dois testemunhos com registros expressivos das rochas do Grupo Itararé, provenientes de dois poços perfurados pela Superintendência Regional do Rio Grande do Sul da CPRM (Companhia de Pesquisa de Recursos Minerais) para a exploração de carvão mineral (figura 1).

Os poços foram selecionados também por suas posições geográficas distantes (aproximadamente $380 \mathrm{~km}$ ), para tentar observar a indução astronômica em locações distintas da bacia. Ambos são representados por seções espessas de ritmitos e folhelhos. São eles:

7-RL-04-SC (Projeto Rio Laranjeiras número 4), perfurado em 1979 no município de Anitápolis, Estado de Santa Catarina, com coordenadas UTM $=6919350 \mathrm{~m} ; 673620 \mathrm{~m}$. Folha SG-22Z-C-VI. Possui $191 \mathrm{~m}$ de rochas do Grupo Itararé.

IB-93-RS (Projeto Irui-Butiá número 93), perfurado em 1981 no município de Butiá, no Estado do Rio Grande do Sul, com coordenadas UTM $=6667000 \mathrm{~m} ; 389000 \mathrm{~m}$. Folha SH-22Y-B-I. Possui $71 \mathrm{~m}$ de rochas do Grupo Itararé.

A indução astronômica foi testada em duas escalas, de dezenas de milhares a centenas de milhares de anos (ciclos orbitais) e de anos a centenas de anos, sendo que o estudo nessa última escala resultou na identificação da indução devida aos ciclos solares. Uma vez que a indução foi determinada, foram calculados os tempos de deposição e as taxas de acumulação, chegandose a um alto nível de resolução estratigráfica. A metodologia de análise cicloestratigráfica foi determinada de acordo com a escala de trabalho. A escala dos ciclos orbitais foi analisada a partir de perfis de raios gama e a dos ciclos solares a partir de intervalos escaneados dos testemunhos e da confecção de gráficos de escala de cinza.

Os resultados obtidos foram bastante positivos. No que concerne aos trechos escaneados dos testemunhos, os mesmos mostraram que, como afirmaram Schaaf \& Thurow (1994 e 1997), a análise de imagens digitais terá no futuro um papel fundamental na descrição e na interpretação de testemunhos e amostras de rocha, pois sua utilização com técnicas estatísticas permite não apenas a extração de informações sobre os ciclos de mudança climática, em escalas de tempo de anos até milênios, mas também o estudo da evolução dessas mudanças no tempo e o desenvolvimento de uma escala de tempo absoluta bem mais acurada que qualquer outra disponível no momento (Schwarzacher, 1987, Schaaf \& Thurow 1994 e 1997). A técnica de escanear testemunhos de poços diferentes de uma mesma bacia permite um controle estratigráfico muito além daquele obtido normalmente com técnicas tradicionais. Acima de tudo, a confrontação dos dados provenientes desse tipo de análise com outros dados estratigráficos, geoquímicos e bioestratigráficos, quando possível, pode levar ao conhecimento da evolução de bacias sedimentares numa alta escala de resolução.

GRUPO ITARARÉ As rochas do Grupo Itararé (Gordon 1947 apud França \& Potter 1988) são datadas como eopermianas em Santa Catarina e no Rio Grande do Sul (Daemon \& Quadros 1970, Cazzulo-Klepzig et al. 1980, Marques-Toigo et al. 1989, Lopes et al. 1991, Marques-Toigo 1991, Dias 1993a, Dias 1993b, Guerra-Sommer \& Cazzulo-Klepzig 1993) e foram depositadas em ambientes glacial, periglacial e marinho (Castro 1980, Tomazelli \& Soliani Jr. 1982, Aboarrage \& Lopes 1986 apud Lopes 1995, Marques-Toigo et al. 1989, Machado 1989, Castro 1991, Castro e Schneider 1993, Canuto 1993, Dias 1993a, Dias 1993c, Machado 1994, Castro 1995, Lopes 1995, Holz 1995a, Holz 1995b, Santos et al. 1996, Silveira, 2000).

No Rio Grande do Sul, o Grupo Itararé preenche sub-bacias 


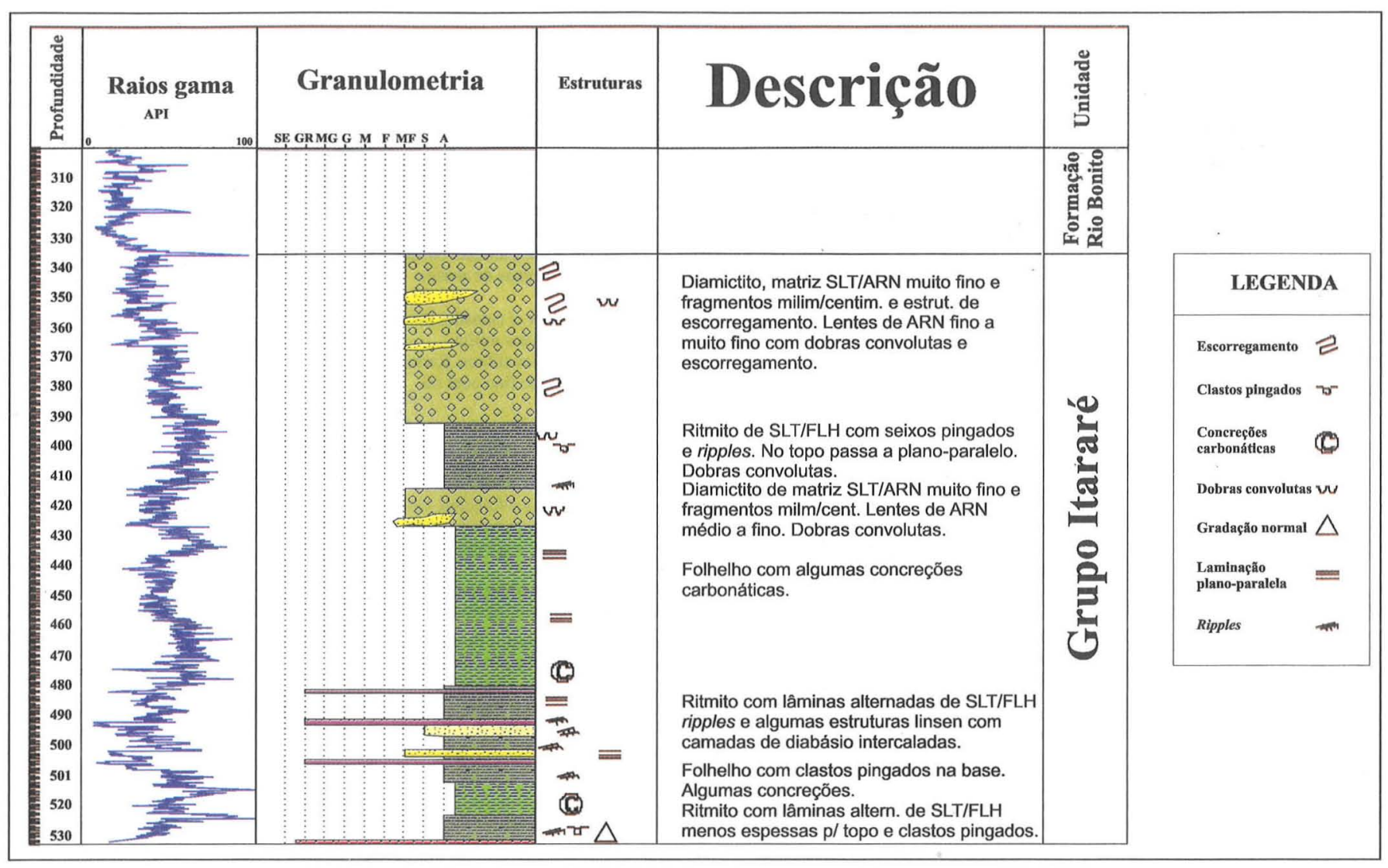

Figura 2- Perfil de raios gama e descrição litológica do poço 7-RL-04-SC.

na borda do Escudo Rio-Grandense, interpretadas como paleovales ou paleofiordes (Aboarrage \& Lopes 1986 apud Lopes 1995, Holz 1995a, Santos et al. 1996), que se alargam em direção ao centro da Bacia do Paraná, e que variam de centenas de metros a poucos quilômetros até depressões de 90 quilômetros de largura por 160 metros de profundidade (Santos et al. 1996). São preenchidas por seqüências de fácies de fluxo de detritos, nos flancos e no fundo dos vales, interdigitadas com fácies fluviais e lacustrinas. O poço IB-93-RS localiza-se no paleovale Leão (Dias 1993a, Lopes 1995, Holz 1995a, Santos et al. 1996, Silveira 2000) (figura 1), cujo ambiente de deposição dos ritmitos foi interpretado por Aboarrage \& Lopes (1986, apud Lopes, 1995) e Dias (1993a e 1993c) como de fiordes e por Silveira (2000) como lagos pró-glaciais em contato direto com o gelo.

A região sudeste de Santa Catarina foi dividida por Castro (1991) em províncias. A província de Alfredo Wagner, onde se localiza o poço 7-RL-04-SC (figura 1), agiu como um centro ativo de glaciação e os sedimentos do Grupo Itararé estão representados, na base, por camadas delgadas de tilitos de alojamento, depositados sobre uma superfície erosiva esculpida pelo gelo, sobrepostas por varvitos e diamictitos de fluxo, que diminuem gradualmente de espessura, sendo cobertos por folhelhos marinhos. Acima dessa sucessão ocorrem arenitos de leques de lavagem subaquosos, recobertos por diamictitos, arenitos e siltitos que gradam para varvitos, folhelhos e siltitos. Essa associação de fácies indica que o nível relativo do mar variou de acordo com o avanço e recuo das condições glaciais (Machado 1989, Castro 1991, Castro e Schneider 1993, Canuto 1993, Castro 1995, Santos et al. 1996) e que as seqüências depositaramse em reentrâncias ou inlets costeiros isolados periodicamente pelas oscilações do nível do mar (Machado 1989, Castro 1991, Santos et al. 1996).
TESTEMUNHOS E PERFIS A presença de ritmitos foi a condicionante primária para a escolha dos testemunhos. Dessa forma, o teste da ocorrência de periodicidade, anual (varvitos) ou outra qualquer, seria possível. Os trechos de testemunho trabalhados possuem espessura total de ritmitos compatível com o objetivo do trabalho. O topo das lâminas dos ritmitos foi considerado praticamente plano para distâncias laterais consideráveis e as profundidades apresentadas são as medidas originalmente quando da amostragem dos testemunhos.

Os detalhes da metodologia usada para a obtenção das séries temporais estão descritos no artigo CEGI-1, nesta publicação.

Testemunho do poço 7-RL-04-SC O intervalo escaneado $(525,47$ a $526,7 \mathrm{~m})$ possui uma espessura total de $1,23 \mathrm{~m}$ e é formado por pares de lâminas alternadas de siltito cinza claro e folhelho cinza escuro, caracterizando uma seqüência rítmica (Einsele et al. 1991). O contato entre as lâminas de siltito e folhelho é abrupto.

A espessura das lâminas de siltito varia entre 0,1 e $0,5 \mathrm{~cm}$, chegando a até $1,1 \mathrm{~cm}$, e as lâminas de folhelho possuem de 0,1 a $0,2 \mathrm{~cm}$ de espessura média. As lâminas de siltito apresentam internamente ripples unidirecionais com parte do foreset preservado. A base de cada lâmina é marcada por uma fina deposição de chuva de detritos provenientes de icebergs.

Da base até o topo do intervalo escaneado existem aproximadamente 413 pares, que se agrupam em feixes assimétricos de três a sete pares, de espessura crescente para o topo, os quais se agrupam em feixes assimétricos maiores de até trinta pares, com as mesmas características. Observa-se uma grande quantidade de clastos pingados nos ritmitos, cuja granulometria varia de areia fina a seixo.

Acima do intervalo estudado as lâminas diminuem de espessura, gradando para um folhelho laminado. A seção do 7-RL- 


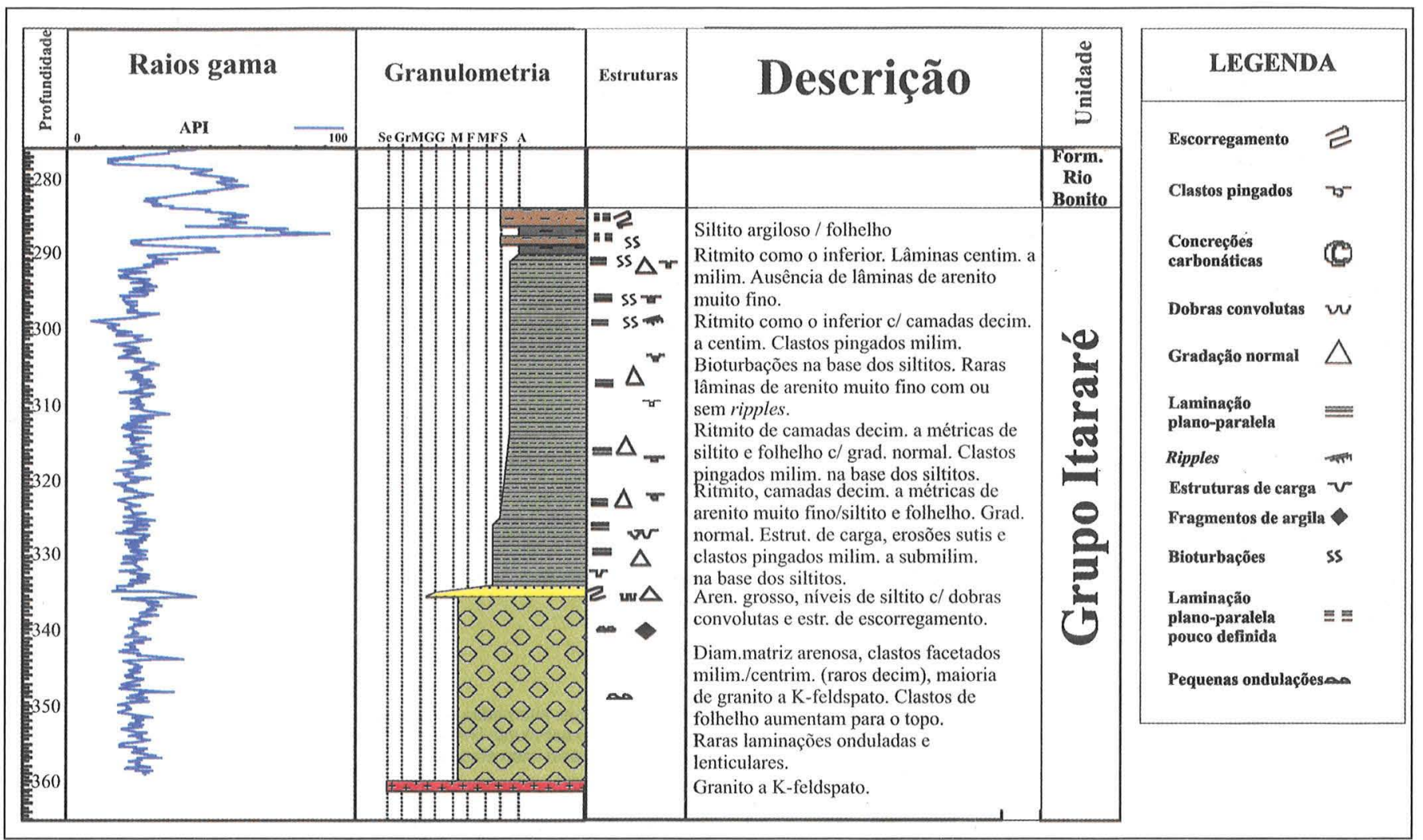

Figura 3- Perfil de raios gama e descrição litológica do poço IB-93-RS.

04-SC está descrita na figura 2, juntamente com o perfil de raios gama.

A fragilidade do testemunho do poço 7-RL-04-SC possibilitou apenas a digitalização de um comprimento de $1,21 \mathrm{~m}$, que teve de ser dividido em dois $(81 \mathrm{~cm}$ e $40 \mathrm{~cm})$ devido à presença de uma pequena falha de rejeito quase imperceptível (artigo CEGI-1). Isto não representou problema, pois ambas continham espessura suficiente para satisfazer as premissas da análise.

O intervalo de amostragem (IA) utilizado foi de $1 \mathrm{~mm} / 3,94$ pontos, ou seja, igual a $0,2538 \mathrm{~mm}$. Os intervalos analisados foram dois: 525,47 a $525,87 \mathrm{~m}$ e 525,89 a $526,70 \mathrm{~m}$.

Testemunho do poço IB-93-RS A base da seção apresenta um diamictito de aproximadamente $25 \mathrm{~m}$ de espessura e matriz de granulação areia fina a média, em contato discordante com um granito a K-feldspato, representando a base do Grupo Itararé. Acima do diamictito ocorre um arenito grosso, de cerca de 1 $\mathrm{m}$ de espessura, com lâminas internas milimétricas de siltito, deformado por dobras convolutas, evidenciando escorregamento.

A partir de 334 m inicia-se uma sucessão de depósitos rítmicos com gradação normal, o primeiro de arenito muito fino e folhelho e os demais, até a profundidade de $290 \mathrm{~m}$, formados por pares de siltitos laminados e folhelhos. Essa sucessão pode ser classificada como uma seqüência rítmica (Einsele et al. 1991).

O contato das camadas de siltito e de folhelho é gradativo. A espessura das camadas dos siltitos varia de decímetros a metros e dos folhelhos de milímetros a centímetros.

As camadas de siltito são marcadas na base por pequenas estruturas de carga, ocasionais clastos pingados milimétricos a submilimétricos e evidências de erosão. Bioturbações no plano da base das camadas tornam-se freqüentes à medida que a espessura diminui para o topo da seção, diferenciando o ambiente de deposição desses ritmitos daqueles do 7-RL-04-SC e sugerindo águas mais oxigenadas, com maior conteúdo de nutrientes.
A espessura dos pares, gradativamebte menor para o topo do testemunho, torna-se milimétrica, e o intervalo analisado (290,08 a 290,46 m) faz parte dessa última intercalação. Toda a seção do IB-93-RS até a profundidade de 290,46 m apresenta cerca de 561 pares. Especificamente no intervalo analisado pode-se observar que os pares se agrupam em feixes de três, sete e até mais de vinte pares, com espessura crescente para o topo.

Esses ritmitos podem ser classificados como turbiditos e representam um distanciamento gradativo da área fonte, ou subida do nível de base, tornando-se, para o topo da seção, mais distais e formados por fluxos de baixa densidade (ver também Silveira 2000).

O perfil de raios gama e a descrição geral do testemunho IB93-RS estão representados na figura 3.

Quanto ao testemunho do poço IB-93-RS, a maior parte da seção do Grupo Itararé é formada por uma seqüência rítmica. Portanto, optou-se por utilizar apenas um pequeno trecho na análise espectral, que possui laminação milimétrica (de 290,08 a 290,46 m). Sendo as fácies rítmicas próximas à base do testemunho semelhantes às das porções superiores, e sendo estas últimas representativas do conjunto em termos da ciclicidade, com conteúdo intrínseco em tempo maior devido às menores taxas de acumulação e características estacionárias favoráveis à análise espectral (Weedon 1991), tornou-se desnecessário utilizar toda a seção.

O intervalo de amostragem (IA) foi o mesmo do outro testemunho, $1 \mathrm{~mm} / 3,94$ pontos, ou igual a $0,2538 \mathrm{~mm}$. Foi analisado o intervalo de 290,08 a 290,46 m.

Dados dos perfis de raios gama $\mathrm{O}$ intervalo de amostragem foi de $1 \mathrm{~cm}$ para ambos os perfis.

Como o poço 7-RL-04-SC perfurou algumas camadas de diabásios mesozóicos, os picos referentes iriam causar ruídos na análise e foram eliminados do perfil, acarretando correção 
de 5,98 $\mathrm{m}$ a partir da camada de diabásio mais profunda (ver detalhes no artigo CEGI-1).

CICLOESTRATIGRAFIA É possível estabelecer uma relação de causa e efeito entre os ciclos indutores climáticos externos e a sedimentação, a partir de análises matemáticas feitas com séries temporais. Contudo, para que essa indução seja observada no registro sedimentar, o ambiente de deposição em questão deve ter características de preservação específicas. Regiões tectonicamente estáveis, sistemas lacustres, baías e áreas marinhas protegidas do retrabalhamento por ondas são os melhores candidatos. Por outro lado, deltas e planícies de maré são geralmente inadequados, pois o registro das mudanças climáticas ou de variação do nível de base estão sujeitas à parcial ou total obliteração, devido a processos autocíclicos e aos grandes hiatos característicos da deposição e preservação de sedimentos em ambientes de alta energia (Algeo \& Wilkinson, 1988).

Os ciclos abordados nesse trabalho, orbitais e solares, foram encontrados nos perfis de raios gama e nos testemunhos dos poços 7-RL-04-SC e IB-93-RS, de acordo com a metodologia apresentada no artigo CEGI-1, nesta mesma publicação. Ambos foram tratados como séries temporais imperfeitas e analisados dessa forma pela análise harmônica, utilizando-se a transformada simples de Fourier.

Seqüências e ciclos de alta freqüência Segundo Schwarzacher (1975), apenas através da observação de um longo intervalo de repetição de camadas semelhantes, e não de uma única unidade, pode-se assumir uma taxa média de acumulação na formação das mesmas e, assim, relacionar a espessura da sucessão sedimentar ao tempo de deposição, pois a identificação dos depósitos com seu significado temporal só pode ser alcançada através de análises estatísticas. Como estas exigem uma grande quantidade de amostras, a necessidade de um intervalo repetitivo longo é essencial.

O termo "ciclo" é aplicado a uma série de tipos de rocha que se repetem de maneira preditiva e onde ao menos um tipo, tomado como ponto inicial, é repetido. Porém, a preditibilidade absoluta não existe em geologia e os ciclos sedimentares devem ser reconhecidos como podendo ser divididos em autocíclicos, provocados por processos internos à bacia, e alocíclicos, induzidos por processos externos (Schwarzacher 1975).

Exemplos de variações no acamamento causadas por processos autocíclicos são os tempestitos, os turbiditos, os episódios de inundação em planícies aluviais e as camadas de cinzas vulcânicas. Porém, processos alocíclicos, e portanto periódicos, também podem afetar a freqüência ou a intensidade dos eventos deposicionais (Einsele et alii, op. cit.). Exemplos disso são as cheias e as secas regulares em conseqüência das monções na Ásia e na África, ligadas aos ciclos solares (Ji et alii, 1993; Von Rad et alii, 1999) e a periodicidade da ocorrência de ciclones tropicais ao longo do oeste do Pacífico, ligadas aos ciclos de El Niño e à Oscilação Quase-Bienal (Labitske, 1987; Linacre \& Geerts, 1997).

Algumas vezes, o efeito combinado dos ciclos indutores no clima e na sedimentação tende a criar uma periodicidade com grandes variações de amplitude e mudanças em certos intervalos de tempo. Assim, fenômenos alocíclicos podem parecer aperiódicos e a única forma de se determinar sua periodicidade é através da análise de séries temporais.

Entre os fenômenos de indução externa de mais alta freqüência que afetam a sedimentação estão as marés e as mudanças anuais de temperatura e precipitação, ambos causados pela interação da Terra com outros astros. As marés possuem períodos de aproximadamente 14 ou 28 dias, dependendo da região do glo- bo, produzindo estruturas sedimentares características dessa periodicidade. As mudanças anuais de temperatura e precipitação, mais especificamente as diferenças climáticas entre o inverno e o verão, são causadas pela variação da insolação ao longo do ano e são responsáveis pelas alternâncias no padrão de sedimentação de algumas bacias, como lagos glaciais ou bacias evaporíticas, que apresentam modificações no conteúdo sedimentar e no padrão de sedimentação. Os registros da espessura dessas camadas, ou varves, por serem uma função de fatores climáticos, comportam-se como séries temporais meteorológicas imperfeitas que permitem uma análise harmônica (Anderson, 1963). Da mesma forma, os registros dos depósitos de maré, quando não obliterados, também podem ser analisados por séries harmônicas, assim como qualquer registro sedimentar que possua uma periodicidade ligada a fatores indutivos externos.

A cicloestratigrafia trabalha principalmente com dados de ciclos ou seqüências de alta freqüência. Entendem-se aqui como ciclos de alta freqüência as seqüências e parasseqüências de quarta ou maior ordem e os ciclos climáticos de dezenas a centenas de anos não relacionados a variações do nível de base, marinho ou lacustre.

Existem dificuldades para se observar essas seqüências, pois podem não ter se desenvolvido de forma suficiente em todos os pontos de uma bacia (Mitchum \& Van Wagoner, 1991).

A preservação dos ciclos e seqüências de diferentes freqüiências depende da amplitude relativa, ou magnitude, dos mesmos, e das condições de preservação do registro sedimentar nos diferentes pontos de uma bacia. Ambientes menos sujeitos à ação do retrabalhamento por ondas, ao tectonismo, ou a efeitos autocíclicos são mais propícios à preservação de depósitos nessa ordem de freqüência (Algeo \& Wilkinson, 1988).

Seqüências de alta freqüência ocorrem normalmente em bacias onde a taxa de sedimentação foi muito alta e a subsidência tectônica lenta, permitindo uma espessura sedimentar suficiente para registrar flutuações menores do nível do mar. Se a subsidência é lenta, pequenas quedas eustáticas seriam bem representadas como quedas relativas do nível do mar. Por outro lado, em bacias onde a subsidência tectônica é alta, as quedas eustáticas pequenas de alta freqüência seriam menos passíveis de representação, pois, para compensar uma taxa alta de subsidência, as quedas eustáticas devem ocorrer numa taxa mais alta ainda para produzir uma queda relativa (Mitchum \& Van Wagoner, 1991).

Porém, seqüuências de alta freqüência podem ser preservadas também em situações de alta taxa de subsidência. Se imaginarmos uma posição proximal dentro de uma bacia onde a taxa de subsidência seja alta, o espaço disponível de acomodação poderá ser grande o suficiente para permitir a deposição de sedimentos e, ao mesmo tempo, registrar com mais facilidade as variações eustáticas de alta freqüência que, devido à proximidade com a linha de costa, ficarão registradas como várias superfícies de erosão.

Diante do exposto até este ponto, pudemos verificar que os fenômenos periódicos do registro sedimentar ocorrem desde a escala de lâminas e camadas até a de grandes sequiências deposicionais e que a escala desses ciclos, ou seja, sua ordem de recorrência, depende do mecanismo de indução primário, seja ele astronômico e, portanto, atuando ciclicamente no clima, ou tectônico. Como citado anteriormente, os ciclos que interessam a esse trabalho são os relacionados a períodos de 500 mil anos ou menos.

\section{CICLOS SOLARES}

Fenômenos atmosféricos devidos às atividades solares e seus registros Os efeitos da atividade solar, incluindo os climáticos, podem ser observados na Terra através de alguns fenômenos específicos, como as auroras boreais e austrais, os níveis do 
isótopo do carbono ${ }^{14} \mathrm{C}$ nos anéis das árvores e os de ${ }^{10} \mathrm{Be}$ em testemunhos de gelo.

Outro material de estudo para determinação de ciclos ligados à variabilidade climática são as varves, que podem evidenciar ciclos anuais ou de maior freqüência. Kukal (1990) catalogou varves e varvitos de várias regiões do mundo, de diferentes idades, e constatou que ciclos de dois e três anos são comuns, assim como ciclos de cinco e seis anos, coincidentes com os ciclos de El Niño. Mais evidentes são os ciclos de dez a quinze anos, que podem corresponder aos ciclos de manchas solares, os quais não são tão regulares quanto imaginam alguns autores. Existem entre oito e dezessete anos entre dois máximos de manchas solares e o número adotado de onze anos é apenas uma média estatística (Eddy, 1977, apud Kukal, 1990). Ciclos correspondentes ao período de onze anos, períodos similares, ou seus múltiplos, têm sido identificados em quase todos os sedimentos várvicos. Isso significa que praticamente cada grupo de onze pares de lâminas em varves ou varvitos deveria diferir de alguma forma dos precedentes. Kukal (1990) acredita que, por essas razões, seja provável que o ciclo de manchas solares tenha existido no passado geológico. Segundo o autor, a quantidade de dados que sugerem a existência do ciclo de onze anos e de seus correlativos é tão grande que dificilmente seria acidental. Por exemplo, o ciclo de 22 anos, ou de Hale, aparece em cinco dos oito exemplos apresentados por ele.

\section{Periodicidades solares observadas nos registros terrestres}

Segundo Crowley \& North (1991), há muito tempo se sabe que o ciclo magnético solar envolve períodos de 11 e 22 anos. Mas os registros terrestres mostram também outros ciclos. Existe um ciclo de 88 anos nas variações das manchas solares e auroras, além de evidências para um período solar fundamental de cerca de 420 anos, com harmônicos significantes em 140 e 220 anos. Nos últimos tempos, registros meteorológicos relativos à circulação atmosférica superior têm sido convincentemente correlacionados à variabilidade solar (Crowley \& North, op. cit.) e observações a partir de satélites confirmaram uma ligação entre a energia total emitida pelo Sol e o ciclo de manchas solares (Stuiver et alii, 1997). Além disso, muitos dos principais avanços glaciais dos últimos 10 mil anos parecem ter ocorrido próximo a épocas de variabilidade solar. Existem também evidências de outros períodos, como 80 anos, verificado em avanços glaciais, anéis de árvores e testemunhos de gelo, 140 anos, observado em avanços glaciais, e 114 e 200 ou 210 anos, observados em anéis de árvores (Johnsen et al., 1970; Sonett \& Suess, 1984; Damon \& Linick, 1986; Stuiver \& Braziunas, 1989; Crowley \& North, 1991; Stuiver et alii, 1995).

Um resumo das periodicidades ligadas aos ciclos solares encontradas em diferentes publicações está apresentado na tabela 1. Algumas têm ligação direta com ciclos de nomes conhecidos na literatura, outras são claras representações de harmônicos desses ciclos. De qualquer forma, todas estão conectadas a variações importantes no clima da Terra, numa freqüência normalmente não observada em trabalhos de geologia.

Observando os dados da tabela 1 , nota-se que os ciclos observados nos registros terrestres, induzidos pela variação solar, devem ser considerados como quase-periódicos. Como existem várias periodicidades ligadas aos ciclos solares, desde 11 até cerca de 3000 anos, cada uma com amplitudes características, a interferência de cada um desses ciclos no outro provoca diferentes efeitos combinados no clima e na sedimentação. Além disso, os períodos definidos de 11 anos e os de menor freqüência são na realidade valores médios, o que contribui para a quaseperiodicidade.

\section{Periodicidades orbitais no tempo geológico Periodicidades}

Tabela 1 - Periodos fundamentais relativos aos ciclos solares, suas respectivas denominações e os ritmos relacionados aos mesmos encontrados em diversas evidências terrestres. $A$ coluna da esquerda mostra a faixa de periodos de recorrência das pequenas eras do gelo (Eddy, 1976). Os nomes e os periodos fundamentais dos ciclos foram baseados em Glenn \& Kelts (1991) e Hoyt \& Schatten (1997).

\begin{tabular}{|c|c|c|c|c|}
\hline & $\begin{array}{l}\text { PERIODO } \\
\text { (anos) }\end{array}$ & MIOTO & Rrunos & EVIDENCTAS \\
\hline \multirow{15}{*}{ 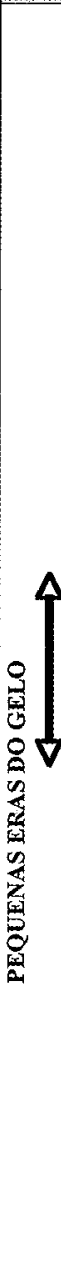 } & $\begin{array}{c}8 \text { a } 17 \\
\text { (média de } \\
11 \text { ) }\end{array}$ & Schwabe & $\begin{array}{l}8,10,11 \\
12,14,15\end{array}$ & 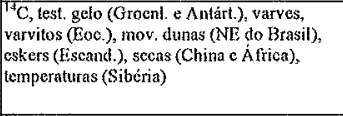 \\
\hline & 20 a 23 & $\begin{array}{c}\text { Hale } \\
\text { (magnético) }\end{array}$ & $\begin{array}{c}20,21,22 \\
25,26\end{array}$ & $\begin{array}{l}\text { C, varves, varyitos (Devon.), secas (EUA), } \\
\text { secas (China e Atrica), test. gelo (Groenl), } \\
\text { taxa de evap/ppt (lagos holoc.), pres. Atmos., } \\
\text { temper.(Siberia), mov. dunes (NE do Brasil) }\end{array}$ \\
\hline & & & $30,31,39$ & $\begin{array}{l}\text { "C, temper.(Siberia), evap'ppt (lagos holoc.), } \\
\text { varves }\end{array}$ \\
\hline & Cerca de 44 & $\begin{array}{c}\text { Duplo de } \\
\text { Hale e } \\
\text { variações no } \\
\text { campo } \\
\text { geomagnétic } \\
o\end{array}$ & $\begin{array}{l}40,44 \\
45 \\
50\end{array}$ & $\begin{array}{l}{ }^{13} \mathrm{C} \text {, varves, secess (China), temper.(Antar). } \\
\text { test. gelo (Groenl.), evap'ppt (laggos holoc.) }\end{array}$ \\
\hline & & & $56,60,61$ & $\begin{array}{l}\text { "T, fest. gelo (Groenl.), varves, } \\
\text { seeas (China e Africat) }\end{array}$ \\
\hline & 80 a 90 & Gleissberg & $\begin{array}{c}68,70 \\
78 \\
80,85 \\
87 \\
88,90 \\
95 \\
100 \\
\end{array}$ & $\begin{array}{l}\text { C, varvitos (Jur), varvitos (Devon), varves, } \\
\text { lest. gelo (Groentândia), avanços glaciais. } \\
\text { sceas (China e África), temper.(Antar.). } \\
\text { taxa de evap/ppt (lagos holocènicos) }\end{array}$ \\
\hline & & & $\begin{array}{l}114,120 \\
125,127 \\
140,150\end{array}$ & $\begin{array}{l}{ }^{17} \mathrm{C}_{\text {, varves, test gelo (Groenlândia), avanģos }} \\
\text { glaciais }\end{array}$ \\
\hline & $\begin{array}{c}179 \mathrm{e} \\
180 \text { a } 208\end{array}$ & $\begin{array}{l}\text { King Hele e } \\
\text { Seuss }\end{array}$ & $\begin{array}{l}160,165 \\
181,187 \\
200,210 \\
220,250\end{array}$ & $\begin{array}{l}\text { Th, varves, varvitos (Jur), avanços ghaciais, } \\
\text { test, gelo (Groent.), evap/ppt (lagos holoc.), } \\
\text { temperatura, secas (China e Africa) }\end{array}$ \\
\hline & & & 270,300 & Taxa de evap/ppt (lagos holocênicos) \\
\hline & & & 400,420 & $\begin{array}{l}\text { UC, avanços glaciais, testemunhos de gelo } \\
\text { (Oroenlândia) }\end{array}$ \\
\hline & & & 500,520 & ${ }^{\mathrm{D} C \text { C, paleotemperaturas, lest. gelo (Groent.) }}$ \\
\hline & & & 640 & Pal eotemperaturas \\
\hline & & & $\begin{array}{l}750,800 \\
830,850\end{array}$ & 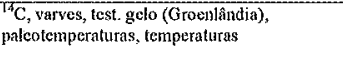 \\
\hline & & & $\begin{array}{l}1050 \\
1100\end{array}$ & 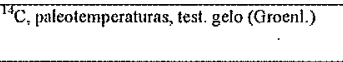 \\
\hline & & & $\begin{array}{l}2400 \\
2500 \\
3000\end{array}$ & $\begin{array}{l}{ }^{1+} \mathrm{C} \text {, palcotempetaturas, test. gelo (Groenll), } \\
\text { avargyos glaciais, temperaturas }\end{array}$ \\
\hline
\end{tabular}

ligadas aos ciclos orbitais têm sido observadas também em registros sedimentares pré-quaternários, o que levou Berger \& Loutre (1989) a calculá-las para os últimos 440 milhões de anos. Mais tarde (Berger \& Loutre 1994), utilizaram fontes diferentes para esses parâmetros, de forma que chegaram a duas respostas possíveis, uma para os últimos 440 milhões e outra para os últimos 2,5 bilhões de anos, ambas apresentadas na tabela 2 (os valores utilizados neste trabalho estão em azul).

$\mathrm{Na}$ tabela, apenas a obliqüidade e a precessão estão listadas. A excentricidade, segundo os autores, não teria sofrido variações significantes, o que faz com que as razões precessão:excentricidade e obliqüidade:excentricidade tenham mudado ao longo do tempo geológico (De Boer \& Smith 1994).

ANÁLISE DOS DADOS O trabalho com dados cicloestratigráficos é bastante facilitado quando existe uma bioestratigrafia detalhada da seção estudada, permitindo a comparação do tempo total calculado através dos ciclos com o da biozona. Mas isso só é possível para seções do Cretáceo Superior e do 
Tabela 2 - Valores estimados dos períodos principais da precessão e da obliqüidade ao longo do tempo. Os períodos relativos ao Eopermiano estão em azul (modificado de Berger \& Loutre, 1994).

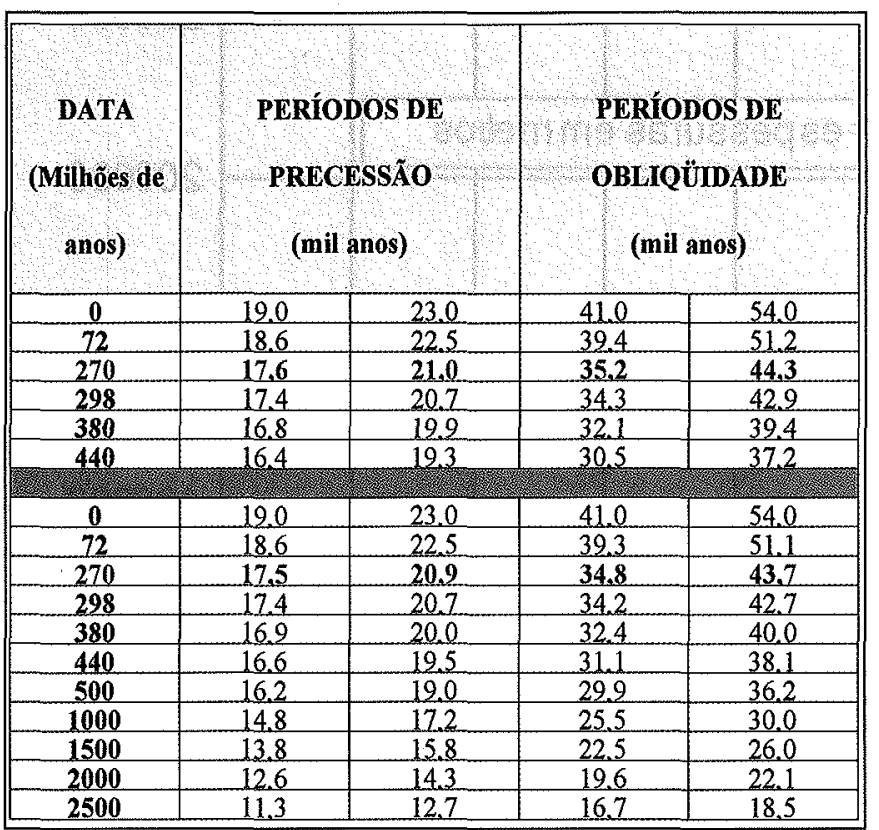

Cenozóico, onde as informações bioestratigráficas são baseadas em nanofósseis ou foraminíferos, que fornecem um detalhamento da ordem de até centenas de milhares de anos. As datações existentes para o Grupo Itararé são baseadas em palinologia, fornecendo um intervalo de deposição máximo entre $4 \mathrm{Ma}$ e $12 \mathrm{Ma}$ tanto no Rio Grande do Sul quanto no sudeste de Santa Catarina (Cazzulo-Klepzig et al. 1980, Marques-Toigo et al. 1989, Lopes et al. 1991, Marques-Toigo 1991, Dias 1993a e 1993b, Guerra-Sommer \& Cazzulo-Klepzig 1993, Ross et al. 1994). Dados confiáveis para a análise de séries temporais exigem espessuras razoáveis de rocha apresentando as mesmas características cíclicas e taxas de acumulação não muito variáveis, para que a série possa ser considerada estacionária. Além disso, o ciclo orbital de maior duração é o de excentricidade, cujas durações principais variam entre períodos curtos e longos com médias de 100 e 400 mil anos, sendo o último valor passível de ser encontrado apenas em seções condensadas ou porções de bacia com taxas de acumulação muito baixas e pouco variáveis. Logo, para se obter espessuras compatíveis, mesmo para o menor tempo de deposição estimado para o Grupo Itararé $(4 \mathrm{Ma})$, seriam necessárias várias dezenas de metros de rocha.

O meio encontrado para verificar a coerência dos tempos calculados nas seções dos poços foi o de comparar as duas escalas diferentes analisadas. Os perfis de raios gama foram analisados procurando-se ciclicidades na escala dos ciclos orbitais e os trechos escaneados dos testemunhos para encontrar evidências na escala de anos a centenas de anos. Se a confrontaç̃o dos cálculos nas duas escalas mostrasse resultados proporcionais, seria possível concluir que os tempos estariam corretos.

As análises foram feitas por intervalos com fácies semelhantes, caracterizando mesmos ambientes e processos deposicionais, e com espessuras semelhantes, seja entre picos nos perfis ou pares e feixes de ritmitos nos testemunhos (Silva 2001 e artigo CEGI-1), denotando taxas de acumulação pouco variáveis, sendo comparáveis a séries temporais estacionárias (Chatfield 1989, Miller e Kahn 1962, Schwarzacher 1987).
Análise dos perfis de raios gama

POÇO 7-RL-04-SC Foram escolhidos três intervalos: 498 a $526,34 \mathrm{~m}, 474$ a $509 \mathrm{~m}$ e 430 a $482 \mathrm{~m}$ (profundidades corrigidas, após a retirada das camadas de diabásio).

Os intervalos acima são formados por ritmitos, folhelhos ou ambos e foram processados pela transformada rápida de Fourier com o do programa Statistica (Statsoft, Inc). Quando a análise de séries temporais fornece uma boa representação dos dados, é possível mostrar que as variações nos mesmos foram induzidas por fenômenos que possuem periodicidades temporais constantes (Harbaugh e Merriam 1968, Einsele et al. 1991). O programa Statistica faz, embutida na análise, a eliminação de tendências.

Após esse processamento, foi gerado o gráfico do periodograma para cada intervalo, também com o programa Statistica. Os períodos obtidos foram dispostos em matrizes e correlacionados a matrizes temporais (Cottle 1989, Azambuja Filho 1990).

Intervalo de 498 a 526,34 m Será apresentada nesse item toda a metodologia utilizada na análise dos periodogramas, dos perfis e das matrizes de espessura e de tempo (Silva 2001). Para os demais intervalos serão feitos apenas comentários pertinentes e indicados os resultados obtidos.

A figura 4 mostra o intervalo em questão no perfil de raios gama e o periodograma. Deve-se ter na lembrança que os dados amostrados não foram discretizados em tempo e que o mesmo fenômeno cíclico pode estar representado por diferentes espessuras devido a pequenas variações na taxa de acumulação. A escala de tempo é ciclicamente variável, pois estamos lidando com dados discretizados no domínio do espaço. A taxa de acumulação é dada pela razão entre a espessura e o tempo de acumulação. Logo, para um mesmo tempo, espessuras diferentes resultarão em taxas distintas, mas o período em questão, ou seja o ciclo deposicional, é essencialmente o mesmo. Os periodogramas de dados de rocha tendem então a mostrar grupos de valores de freqüência (grupos de picos) que representam o mesmo fenômeno cíclico.

Igualmente, para um dado intervalo escolhido para análise, as freqüências mais baixas tenderão a aparecer divididas no periodograma em grupos menores de picos e as mais altas em grupos mais dispersos, pois como as taxas de acumulação tendem a apresentar uma menor variabilidade para intervalos de tempos maiores, as periodicidades de baixas freqüências aparecerão com taxas mais constantes, enquanto as altas freqüências estarão representadas por várias espessuras no dado original.

O periodograma mostra valores de freqüência, de forma que os mesmos tiveram que ser convertidos para valores de espessura no perfil, dividindo-se o intervalo de amostragem pelas freqüências.

Os valores numéricos acima dos picos mais significativos no periodograma (figura 4) representam os seus correspondentes em espessura. No intervalo em questão, excetuando o pico de $7,1 \mathrm{~m}$, todos os outros possuem valores menores e semelhantes de variância, refletindo dois fatores: primeiro, provavelmente um equilíbrio na resposta aos fatores indutores externos; segundo, a redução da intensidade das altas frequiências, causada por ruídos na modulação da freqüência (Schwarzacher 1989). Pode acontecer que alguns picos do periodograma sejam harmônicos de um dos períodos fundamentais e outros, menos importantes, apenas ruídos.

O segundo passo foi localizar as espessuras no perfil de raios gama. As relações entre as baixas, médias e altas freqüências identificadas no periodograma provam sua coerência, pois os fenômenos indutores (ciclos orbitais) são conectados. Uma espessura que venha a ser ligada ao ciclo de excentricidade de 100 mil anos deve estar relacionada a 4,5 ou 6 outras conectadas ao 

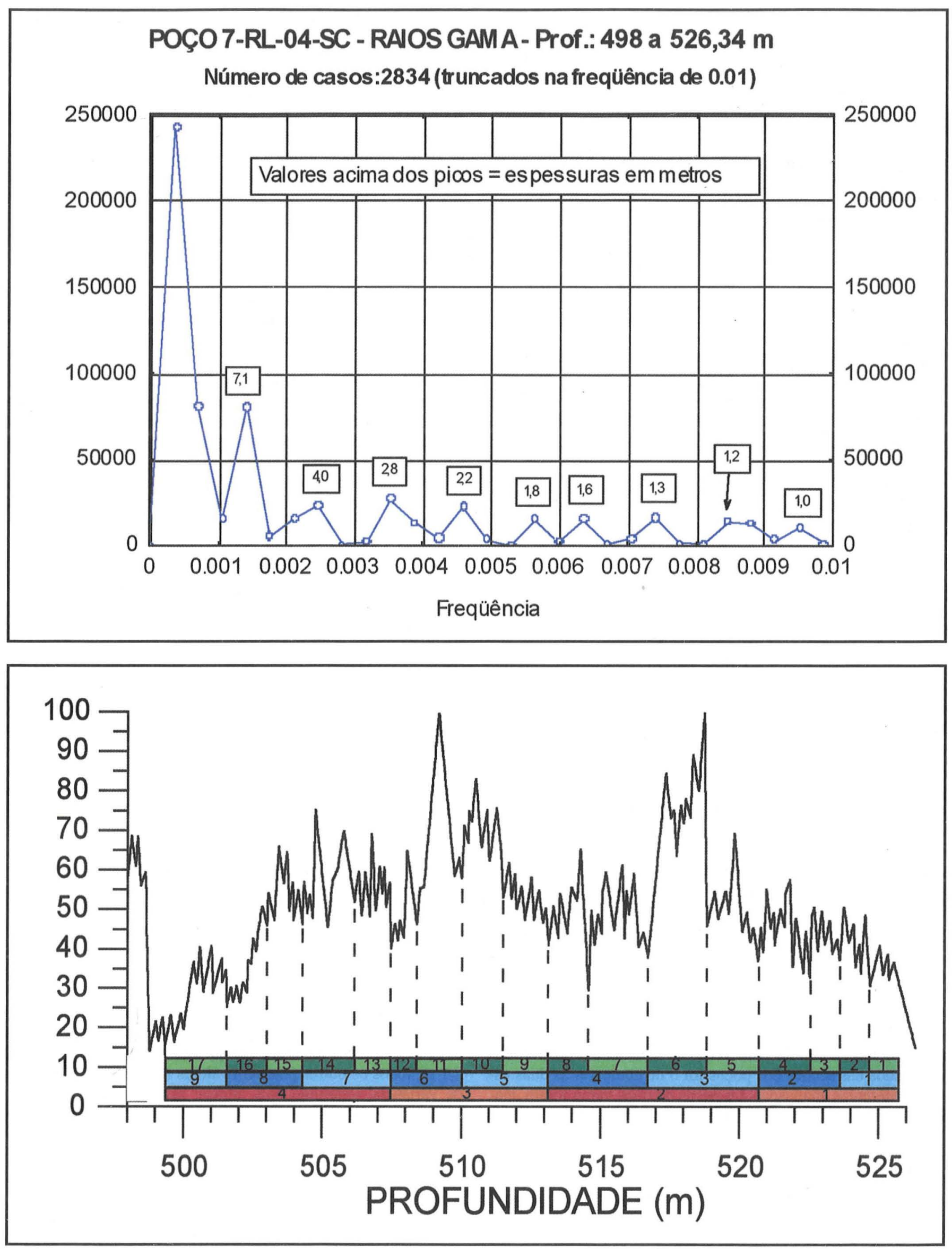

Figura 4-Periodograma (A) e perfil de raios gama (B) do trecho entre 498 e 526,4 $m$ do poço 7-RL-04-SC. O eixo "Valores do Periodograma" da figura (A) pode ser interpretado como a variância da série temporal para cada freqüência. Os periodos encontrados pelo programa Periodo estão marcados e numerados, da base para o topo, no perfil: precessão, em verde; obliqüidade, em azul; excentricidade curta, em laranja e vermelho. 


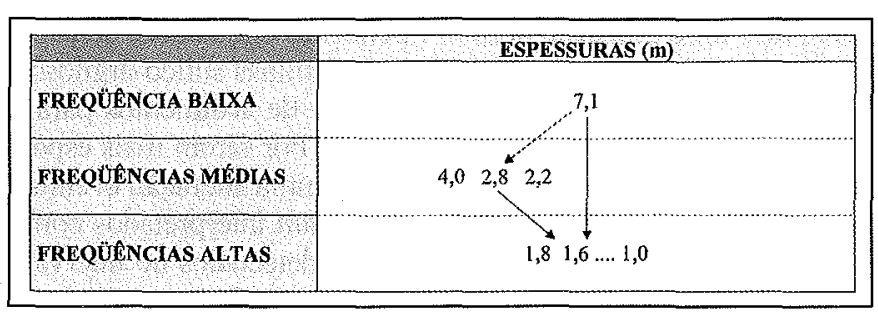

Figura 5-Espessuras ligadas às baixas, médias e altas frequiências encontradas no intervalo de 498 a 526,34 m no perfil de raios gama do poço 7-RL-04-SC e a relação entre elas. É importante ressaltar que essas relações têm que ser verificadas totalmente, as baixas com as médias e altas e as médias com as altas.

ciclo de precessão (cerca de $19 \mathrm{ka}$ ). Como os picos representam ciclos de deposição, o critério de correlação no perfil foi a busca por feições estratigráficas distintas.

Foi possível relacionar as espessuras indicadas pelo periodograma a ciclos de engrossamento e afinamento para o topo, com cada ciclo individual tendo seu início e término em um pico de baixa radioatividade, ou tendência a engrossamento (figura 4).

As espessuras identificadas estão listadas na figura 5, assim como as relações entre elas. A de $7,1 \mathrm{~m}$ representa a freqüência mais baixa, as de 4,0,2,8 e $2,2 \mathrm{~m}$ caracterizam relativamente as freqüências médias e as de 1,8 a $1,0 \mathrm{~m}$ associam-se às altas frequiências. Como os picos do periodograma representam valores médios das frequêencias encontradas pela série de Fourier, algumas variações em relação às espessuras encontradas podem ocorrer.

A correlação entre as matrizes de espessura e de tempo foi feita através do programa Período, de autoria de Maria de Lourdes Esperança, da PETROBRAS. Esse programa, à semelhança da metodologia utilizada por Cottle (1989) e Azambuja Filho (1990), calcula as razões dos valores de período para cada matriz. As razões são então comparadas pela divisão simples dos valores das duas matrizes. Se o resultado da divisão situa-se dentro da faixa de similaridade desejada (no caso, $91 \%$ ), o programa guarda a espessura e o tempo correspondentes às razões semelhantes.

As rochas analisadas estão representadas por espessuras consideráveis de ritmitos finos e folhelhos, denotando grandes intervalos de deposição. Uma matriz de tempo a ser utilizada é a dos períodos orbitais, considerados como os únicos processos regulares (considerando o tectonismo um processo não cíclico) com períodos entre 10 mil e 1 milhão de anos capazes de afetar a sedimentação (Anderson 1963), como tem sido demonstrado na literatura (por exemplo, Hays et al. 1976, Cottle 1989, Fischer \& Robers 1991). Sendo as taxas de acumulação encontradas coerentes, essa é uma boa solução. Os períodos orbitais de obliqüidade e precessão para o Eopermiano foram escolhidos de acordo com a tabela 2 (Berger \& Loutre 1994). Os dados de 410 mil anos para a excentricidade longa e de 95 e 123 mil anos para a excentricidade curta provêm de médias encontradas por Hays et al. (1976) e dos valores indicados por Imbrie \& Imbrie (1980) e De Boer \& Smith (1994). Os valores de 10, 6 e 3 mil anos são derivados de periodicidades encontradas em testemunhos de gelo e sedimentos glaciais (Heinrich 1988, Yiou et al. 1997).

A figura 6 mostra as matrizes de tempo e de espessura para $o$ intervalo referido.

A análise dos resultados considerou as relações entre valores de espessura e tempo que estavam dentro da similaridade de $91 \%$.

Selecionados os pares espessura-tempo, passou-se à obser-

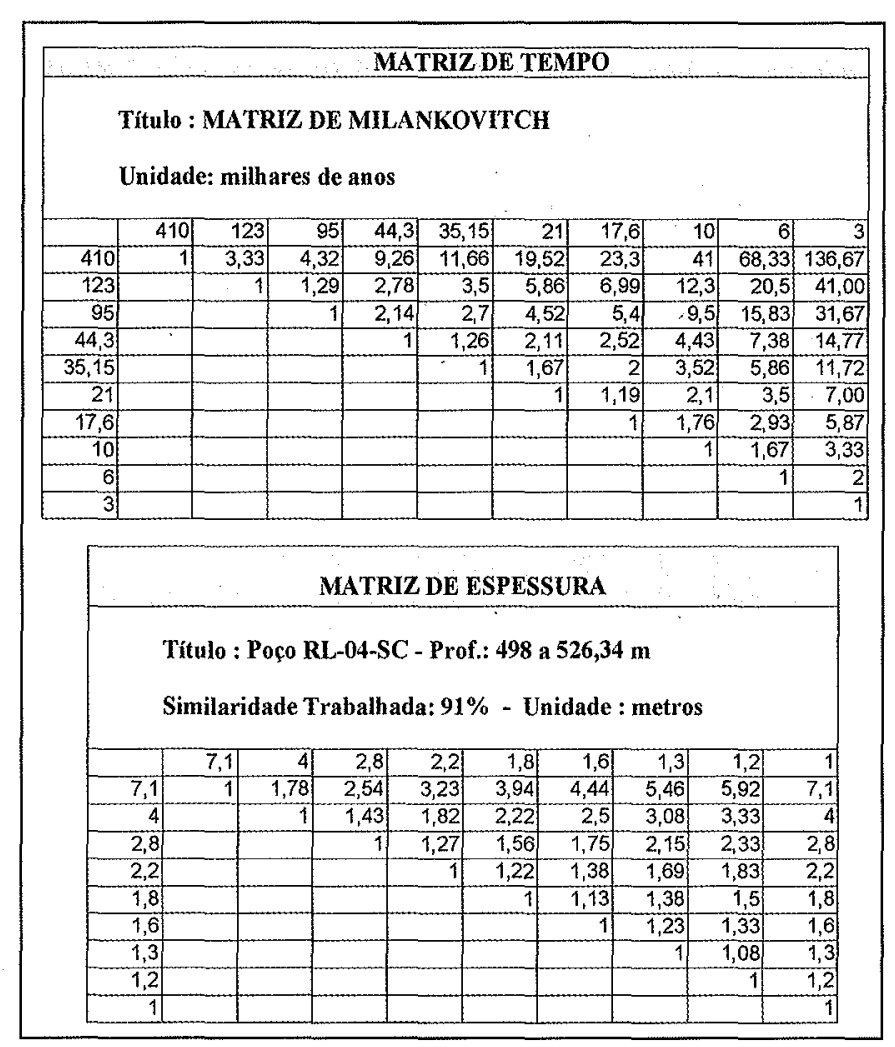

Figura 6-Matrizes de tempo e de espessura para o intervalo de 498 a 526,34 $m$ do perfil de raios gama do poço 7-RL-04-SC.

Tabela 3-Taxas de acumulação para o Permiano, baseadas em dados mundiais (modificada de Kukal, 1990).

\begin{tabular}{|c|c|c|c|}
\hline \multicolumn{3}{|c|}{ Taxas de acumulaç̃o para o Permiano } \\
\hline \multicolumn{3}{|c|}{ (cm/ka) } \\
\hline Máxima para a & Máxima para a & Máxima efetiva & Máxima para \\
América do Norte & Europa & & plataformas \\
\hline 6,2 & 22,4 & 10,0 & 2,3 \\
\hline
\end{tabular}

vação das taxas de acumulação. Quando as diferenças na porosidade e na compactação na seção são negligíveis, as variações de espessura estão diretamente relacionadas às da taxa de acumulação (Ricken 1993). O intervalo analisado possui 28 m, não implicando, portanto, em problemas de compactação diferencial.

Kukal (1990), baseado em dados de Bubnoff (1948, apud Kukal 1990), apresentou taxas de acumulação para o Permiano (tabela 3), baseadas em dados mundiais, mostrando valores máximos em torno de $22 \mathrm{~cm} / \mathrm{ka}$ e mínimos em torno de $2 \mathrm{~cm} / \mathrm{ka}$, com uma média de cerca de $10 \mathrm{~cm} / \mathrm{ka}$. Algumas taxas obtidas não condizem com as de Kukal (1990) e nem são razoáveis para o tipo de ambiente de deposição em questão (baía ou inlet costeiro) (Canuto, 1993, Santos et al. 1996). Logo, valores acima de 20 e abaixo de $2 \mathrm{~cm} / \mathrm{ka}$ foram desconsiderados, mesmo estando dentro da similaridade requerida.

Em seguida, os pares espessura-tempo escolhidos dentro dos pré-requisitos acima foram confrontados para observar sua coerência. Quanto mais relações houvesse entre os pares de baixa, média e alta freqüência, ou seja, quanto mais vezes as mesmas fossem detectadas, de acordo com as interações entre as espes- 
Tabela 4 - Espessuras e períodos correspondentes de Milankovitch para o intervalo entre 498 e $526,34 \mathrm{~m}$ do poço 7-RL-04-

\begin{tabular}{|c|c|c|c|}
\hline $\begin{array}{c}\text { Espessuras } \\
\text { no perfil } \\
\text { (m) }\end{array}$ & $\begin{array}{c}\text { Períodos } \\
\text { correspondentes } \\
\text { (mil anos) }\end{array}$ & $\begin{array}{c}\text { Ciclo de } \\
\text { Milankovitch }\end{array}$ & $\begin{array}{c}\text { Taxas de } \\
\text { acumulação } \\
\text { (cm/ka) }\end{array}$ \\
\hline 7,1 & 123 a 95 & Excentricidade curta & 5,8 a 7,5 \\
\hline 4,0 & \multirow{3}{*}{44,3 a 35,5} & \multirow{3}{*}{ Obliqüidade } & \multirow{3}{*}{5,0 a 11,3} \\
\hline 2,8 & & & \\
\hline 2,2 & & & \\
\hline 1,8 & \multirow{5}{*}{21 a 17,6} & \multirow{5}{*}{ Precessão } & \multirow{5}{*}{5,7 a 9,1} \\
\hline 1,6 & & & \\
\hline 1,3 & & & \\
\hline 1,2 & & & \\
\hline 1,0 & & & \\
\hline
\end{tabular}

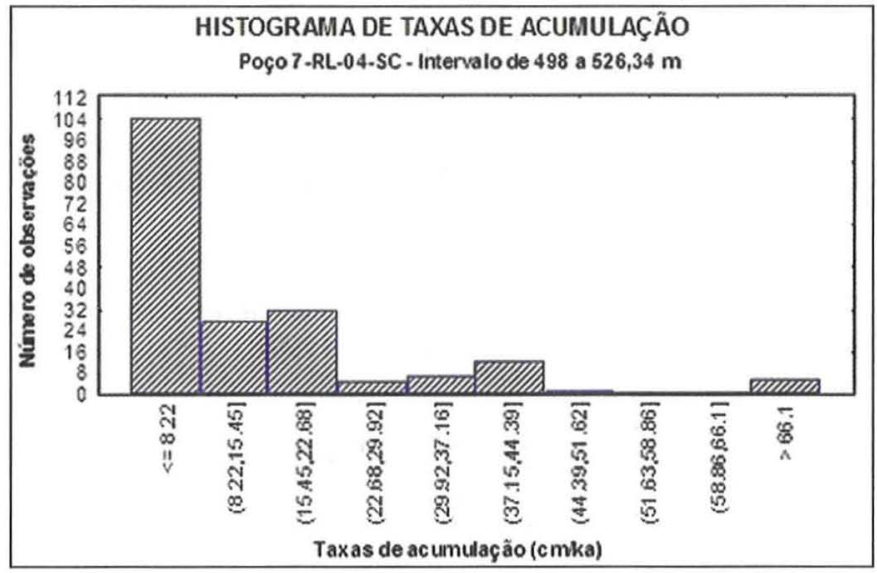

Figura 7 - Histograma das taxas de acumulação para o poço 7-RL-04-SC, no intervalo entre 498 e 526,34 m. As taxas mais freqüentes são as abaixo de $8,22 \mathrm{~cm} / \mathrm{ka}$.

suras reveladas pelo periodograma e o perfil (figura 5), melhor estaria demonstrada a ligação entre os períodos indutivos e as espessuras correlatas. Se alguma das freqüências apresentasse nenhum ou pouco relacionamento com as demais, significaria que os pares espessura-tempo estariam errados. No caso de não existirem boas correlações com nenhuma das opções, a matriz de tempo teria que ser modificada.

Os únicos pares espessura-tempo que caracterizaram grande correlação em todas as freqüências estão na tabela 4 , assim como as taxas de acumulação. Possuem coeficientes de até 99\%, com modas em $91 \%, 93 \%$ e $98 \%$.

A matriz de tempo escolhida mostrou-se correta, indicando a indução externa na sedimentação pelos ciclos orbitais.

Os dados da tabela 4 estão mostrados na figura 4. De acordo com a interpretação, o ciclo de obliqüidade de número 9 está incompleto. O restante do ciclo está incluído no intervalo seguinte. A feição de baixa radioatividade que ocorre aproximadamente entre 499 e $500 \mathrm{~m}$ (eqüivale às profundidades de 501,5 a 502,5 no perfil não corrigido) representa uma intercalação de arenitos decimétricos finos a muito finos, com clastos argilosos dispersos de cerca de 2 mm, gradação normal e pequenas ondulações ou laminações cruzadas no topo, separados por lâminas síltico-argilosas. Esses pares identificam um aporte maior de sedimentos para a bacia ou a maior proximidade da geleira. Por serem mais espessos que o restante dos ritmitos, provocam uma alteração eventual na espessura média dos ciclos. Logo, foram interpretados como fazendo parte dos últimos ciclos orbitais detectados no intervalo (figura 4), assim como dos primeiros do intervalo seguinte.

Outra forma de testar a valịdade dos resultados é a construção de um histograma das taxas de acumulação. Como se pode verificar pela figura 7 , as taxas obtidas representam a maior parte das observações.

Os ciclos limitados por eventos de engrossamento, indicam então a influência dos ciclos orbitais na sedimentação. Cada ciclo individual no perfil caracteriza um ciclo de precessão. Os ciclos de obliqüidade são constituídos por dois no perfil e os de excentricidade curta por quatro a cinco.

Portanto, o tempo total de sedimentação foi, multiplicandose os 17 períodos de precessão encontrados por uma média de 19 mil anos, de aproximadamente 323 mil anos, a uma taxa média de $8,4 \mathrm{~cm} / \mathrm{ka}$. Foram escolhidos os períodos de precessão por serem de mais alta freqüência, fornecendo intervalos de tempo mais acurados.

Intervalo de 474 a $509 \mathrm{~m} \quad \mathrm{O}$ perfil de raios gama e o periodograma são mostrados na figura 8 . O comprimento do intervalo incluiu um trecho do anterior, para que as baixas freqüências fossem melhor amostradas.

Os valores do periodograma possuem uma distribuição diferente do intervalo anterior, mas as dimensões em espessura são bem semelhantes e revelam três conjuntos distintos de picos.

As espessuras calculadas e suas relações, a partir das observações no perfil de raios gama, estão na figura 9. Sua separação no periodograma em três grupos evidencia a hierarquia existente entre elas.

A figura 10 mostra as matrizes de espessura e de tempo (coeficiente de similaridade de $91 \%$ ). Os pares espessura-tempo com maior correlação estão listados na tabela 5.

Como se pode ver (figura 8), os ciclos de precessão de número 4, 10, 11 e 13 possuem espessuras menores que as identificadas no periodograma em picos confiáveis (menor espessura corresponde a $1,3 \mathrm{~m}$ ). Foram, portanto, interpretados tentativamente. Essa dificuldade de observação da precessão pode ser devida à posição latitudinal da bacia no Eopermiano, entre 45 e 500 Sul. A indução climática da precessão normalmente se expressa de forma mais intensa em latitudes mais baixas, próximas ao equador, enquanto a indução da obliqüidade é mais forte nas latitudes médias. Porém, pode também ser devida a variações na taxa de acumulação.

Nota-se (figura 8) que os ciclos de excentricidade são formados por quatro a seis de precessão e não quatro a cinco, como no Pleistoceno. Esse demonstra que 95, 100 ou 123 mil anos para a excentricidade são, na realidade, médias desse período orbital e é uma evidência de que a razão precessão:excentricidade era menor durante o Eopermiano (Berger \& Loutre 1989 e 1994 De Boer \& Smith 1994). Os ciclos de excentricidade de número 3 e de obliqüidade de número 9 não estão completos, continuando no intervalo superior e o ciclo de obliqüidade de número 1 é a continuação do último do intervalo precedente.

Os pares espessura-tempo escolhidos possuem coeficientes de similaridade altos, de até 100\% (modas em 98\% e 99\%). A figura 11 representa o histograma das taxas de acumulação obtidas. A maior parte das observações se insere nas taxas relacionadas aos pares espessura-tempo da tabela 5 .

A contagem do tempo no perfil foi feita a partir do topo do último intervalo, desde o trecho superior dos pares decimétricos 
que ocorrem entre 499 e $500 \mathrm{~m}$, entre cerca de 475,5 a 499,5 m. Entre 477,4 e 474 m, aproximadamente, existem dois picos de baixa radioatividade que representam concreç̃es carbonáticas, não constituindo limites de ciclos.

O tempo total de sedimentação foi de aproximadamente 304 mil anos (16 períodos de precessão vezes uma média de 19 mil anos), a uma taxa média de 7,5 cm/ka (figura 8).

Intervalo de 430 a $482 \mathrm{~m}$ Da mesma forma que para o último, o comprimento do intervalo em questão contemplou
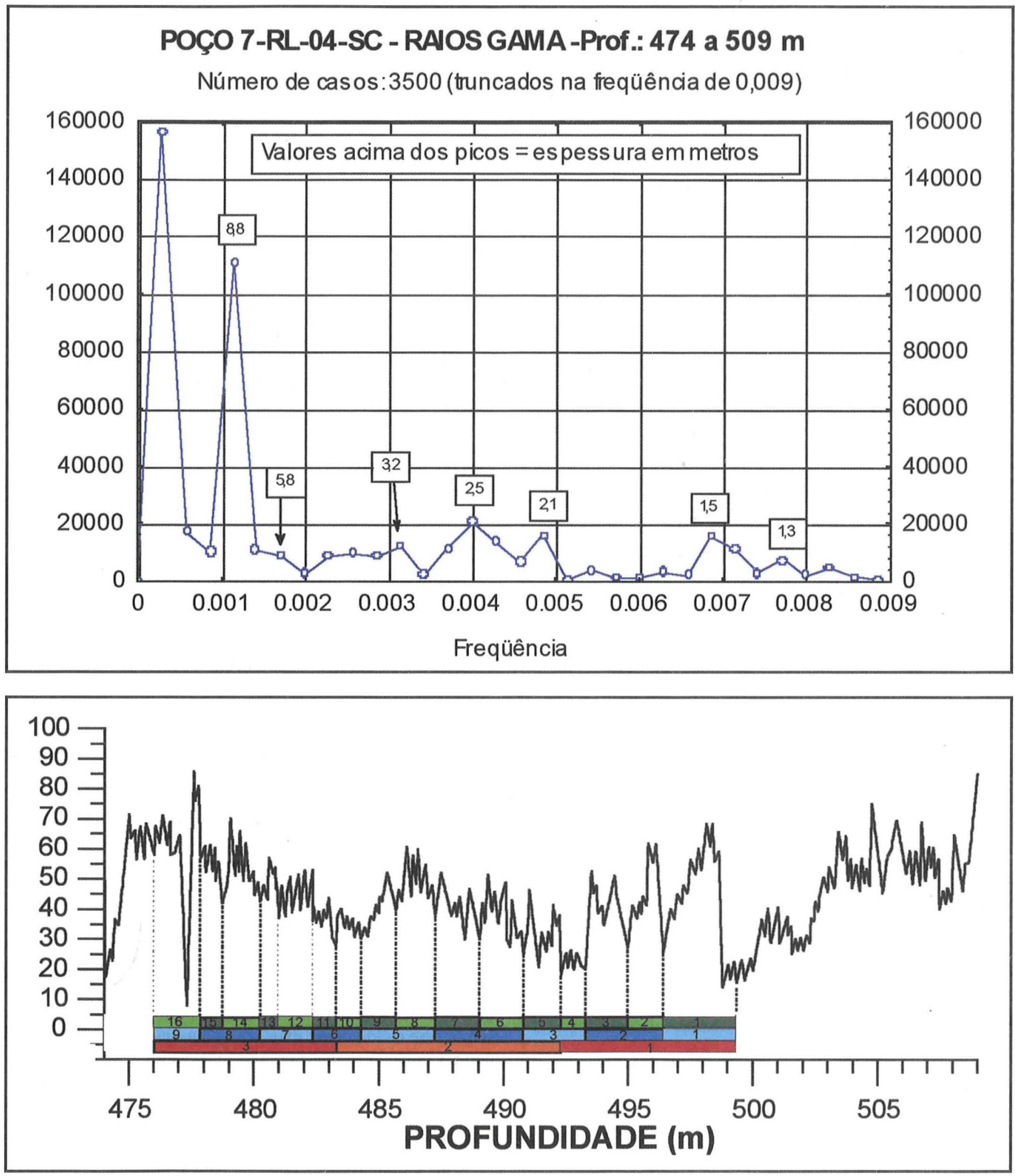

Figura 8-Periodograma (A) e perfil de raios gama (B) do trecho entre 474 e $509 \mathrm{~m}$ do poço 7-RL-04-SC. O eixo "Valores do Periodograma" da figura (A) pode ser interpretado como a variância da série temporal para cada freqüência. Os períodos encontrados pelo programa Período (ver texto) estão marcados e numerados, da base para o topo, no perfil: precessão, em verde; obliqüidade, em azul; excentricidade curta, em vermelho e laranja. 


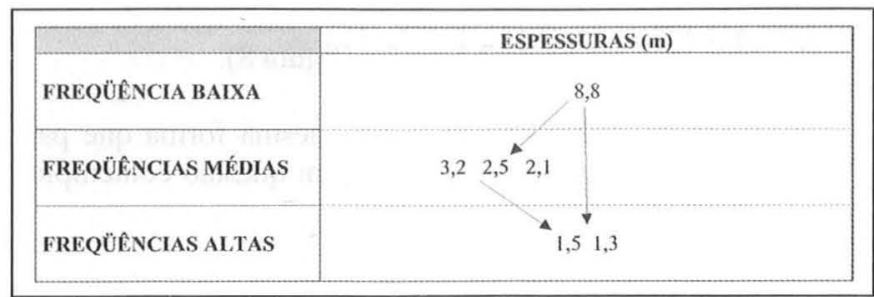

Figura 9-Espessuras ligadas às baixas, médias e altas frequiências encontradas no intervalo de 474 a 509 m no perfil de raios gama do poço 7-RL-04-SC e a relação entre elas.

\begin{tabular}{|c|c|c|c|c|c|c|c|c|c|c|}
\hline \multicolumn{11}{|c|}{ MATRIZ DE TEMPO } \\
\hline \multicolumn{11}{|c|}{ Titulo: MATRIZ DE MILANKOVITCH } \\
\hline \multicolumn{11}{|c|}{ Unidade: milhares de anos } \\
\hline & 410 & 123 & 95 & 44,3 & 35,15 & 21 & 17,6 & 10 & 6 & 3 \\
\hline 410 & 1 & 3,33 & 4,32 & 9,26 & 11,66 & 19,52 & 23,3 & 41 & 68,33 & 136,67 \\
\hline 123 & & 1 & 1,29 & 2,78 & 3,5 & 5,86 & 6,99 & 12,3 & 20,5 & 41 \\
\hline 95 & & & 1 & 2,14 & 2,7 & 4,52 & 5,4 & 9,5 & 15,83 & 31,67 \\
\hline 44,3 & & & & 1 & 1,26 & 2,11 & 2,52 & 4,43 & 7,38 & 14,77 \\
\hline 35,15 & & & & & 1 & 1,67 & 2 & 3,52 & 5,86 & 11,72 \\
\hline 21 & & & & & & 1 & 1,19 & 2,1 & 3,5 & 7 \\
\hline 17,6 & & & & & & & 1 & 1,76 & 2,93 & 5,87 \\
\hline 10 & & & & & & & & 1 & 1,67 & 3,33 \\
\hline 6 & & & & & & & & & 1 & 2 \\
\hline 3 & & & & & & & & & & 1 \\
\hline \multicolumn{11}{|c|}{ MATRIZ DE ESPESSURA } \\
\hline \multicolumn{11}{|c|}{ Título : Poço RL-04-SC - Prof.: 474 a 509 m } \\
\hline \multicolumn{11}{|c|}{ Similaridade Trabalhada: $91 \%$ - Unidade : metros } \\
\hline & & 8,8 & 5,8 & 3,2 & 2,5 & 2,1 & 1,5 & 1,3 & & \\
\hline & 8,8 & 1 & 1,52 & 2,75 & 3,52 & 4,19 & 5,87 & 6,77 & & \\
\hline & 5,8 & & 1 & 1,81 & 2,32 & 2,76 & 3,87 & 4,46 & & \\
\hline & 3,2 & & & 1 & 1,28 & 1,52 & 2,13 & 2,46 & & \\
\hline & 2,5 & & & & 1 & 1,19 & 1,67 & 1,92 & & \\
\hline & 2,1 & & & & & 1 & 1,4 & 1,62 & & \\
\hline & 1,5 & & & & & & 1 & 1,15 & & \\
\hline & 1,3 & & & & & & & 1 & & \\
\hline
\end{tabular}

Figura 10 - Matrizes de tempo e de espessura para o intervalo entre 474 e $509 \mathrm{~m}$ do perfil de raios gama do poço 7-RL-04-SC

Tabela 5 - Espessuras e períodos correspondentes de Milankovitch para o intervalo entre 474 e $509 \mathrm{~m}$ do poço 7-RL-04-SC.

\begin{tabular}{|c|c|c|c|}
\hline $\begin{array}{c}\text { Espessuras } \\
\text { no perfil } \\
\text { (m) }\end{array}$ & $\begin{array}{c}\text { Períodos } \\
\text { correspondentes } \\
\text { (mil anos) }\end{array}$ & $\begin{array}{c}\text { Ciclo } \\
\text { de } \\
\text { Milankovitch }\end{array}$ & $\begin{array}{c}\text { Taxas de } \\
\text { acumulação } \\
\text { (cm/ka) }\end{array}$ \\
\hline 8,8 & 123 a 95 & Excentricidade curta & 7,2 a 9,3 \\
\hline 3,2 & 44,3 a 35,5 & Obliqüidade & 7,1 a 9,1 \\
\hline 2,5 & & & \\
\hline 2,1 & 21 a 17,6 & Precessão & 7,1 a 8,5 \\
\hline 1,5 & & & \\
\hline 1,3 & & & \\
\hline
\end{tabular}

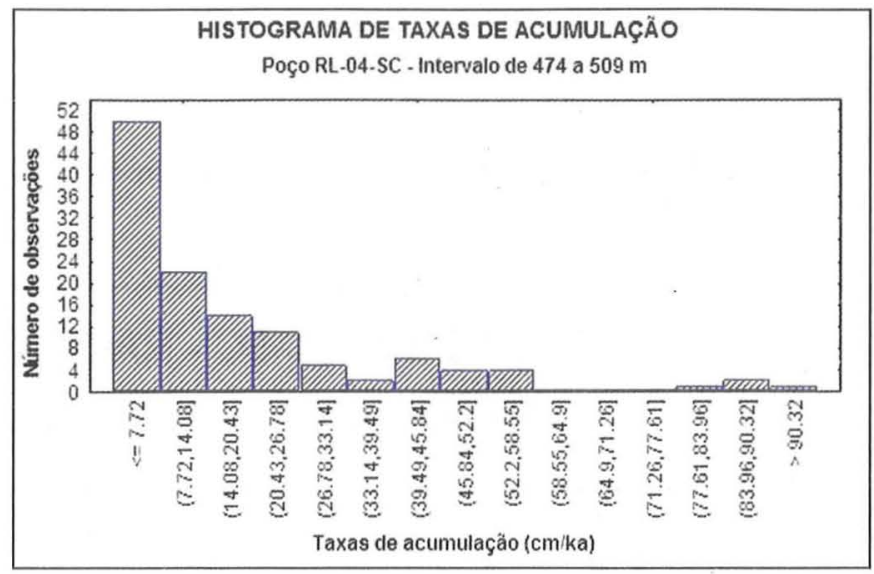

Figura 11 - Histograma das taxas de acumulação para o poço 7 RL-04-SC, no intervalo entre 474 e $509 \mathrm{~m}$. As taxas mais freqüentes são as abaixo de $7,72 \mathrm{~cm} / \mathrm{ka}$.

um trecho do anterior. Os picos do periodograma (figura 12) mostram-se bem distribuídos, com variância maior nas baixas freqüências e na freqüência média correspondente à espessura de 2,3 m. A correlação no perfil caracterizou os de 8,7 e $6,5 \mathrm{~m}$ como baixas freqüências, os de 4,0,2,9 e 2,3 m como médias e os de 1,8, 1,5 e 1,4 m como altas freqüências (figura 13). O pico associado à espessura de $13 \mathrm{~m}$ é um harmônico do comprimento total do intervalo.

As matrizes de espessura e de tempo estão na figura 14 (coeficiente de similaridade de $91 \%$ ). Os pares espessura-tempo correlacionados para o intervalo estão listados na tabela 6 . A correlação entre eles foi maior que nos dois intervalos anteriores.

Assim como no intervalo anterior, vários ciclos de precessão marcados no perfil estão abaixo da menor espessura indicada no periodograma e os ciclos de excentricidade são formados por grupos de até seis de precessão. Os ciclos de excentricidade e de obliqüidade de número 1 são as continuações dos ciclos de excentricidade e obliqüidade de números 3 e 9 , respectivamente, do intervalo inferior.

Os coeficientes de similaridade encontrados variam de $91 \%$ a $99 \%$, com modas em $94 \%, 96 \%$ e $98 \%$. O histograma da figura 15 comprova a validade dos resultados.

O tempo total de sedimentação foi de aproximadamente 551 mil anos (29 períodos de precessão). A taxa de acumulação média foi de cerca de $7,4 \mathrm{~cm} / \mathrm{ka}$ (figura 12). Observado-se as taxas de acumulação médias obtidas para os três intervalos, nota-se que as mesmas diminuem para o topo $(8,4,7,5$ e $7,4 \mathrm{~cm} / \mathrm{ka})$, espelhando, provavelmente, o aumento no conteúdo de folhelhos.

Existe um pacote de ritmitos, entre 426,5 e $432,5 \mathrm{~m}$. A pequena espessura do mesmo $(6 \mathrm{~m})$ impossibilitou a caracterização de um comprimento de perfil compatível para a análise. Portanto, o mesmo foi interpretado observando-se o mesmo padrão dos ciclos de obliqüidade dos intervalos inferiores. Optouse por esse ciclo por ser mais conspícuo que o de precessão no perfil. Contando-se dois períodos observados a partir do último de obliqüidade calculado e multiplicando-se por uma média de 40 mil anos, obteve-se um tempo de 80 mil anos para a deposição do pacote, permitindo a interpretação de um ciclo de excentricidade a mais.

Uma última dedução pode ser feita a partir dos resultados e do padrão de empilhamento da seção. O perfil mostra uma periodicidade de baixa freqüência que apresenta a mesma tendência de engrossamento no topo e na base dos ciclos orbitais encontrados e que coincide com cada quatro ciclos de excentricidade curta. Essa periodicidade pode ser interpretada, tentativamente, 
como representante do ciclo de excentricidade longa (média de 410 mil anos), o qual não foi passível de detecção na análise.

A união final de toda a interpretação dos ciclos orbitais para os intervalos analisados está apresentada na figura 16 e revela um tempo de deposição total de cerca de um milhão, duzentos e cinqüenta e quatro mil anos (1254000 anos), com uma taxa média de acumulação de aproximadamente $79 \mathrm{~m} / \mathrm{Ma}(7,9 \mathrm{~cm} / \mathrm{ka})$.

É interessante comparar os resultados obtidos com as taxas
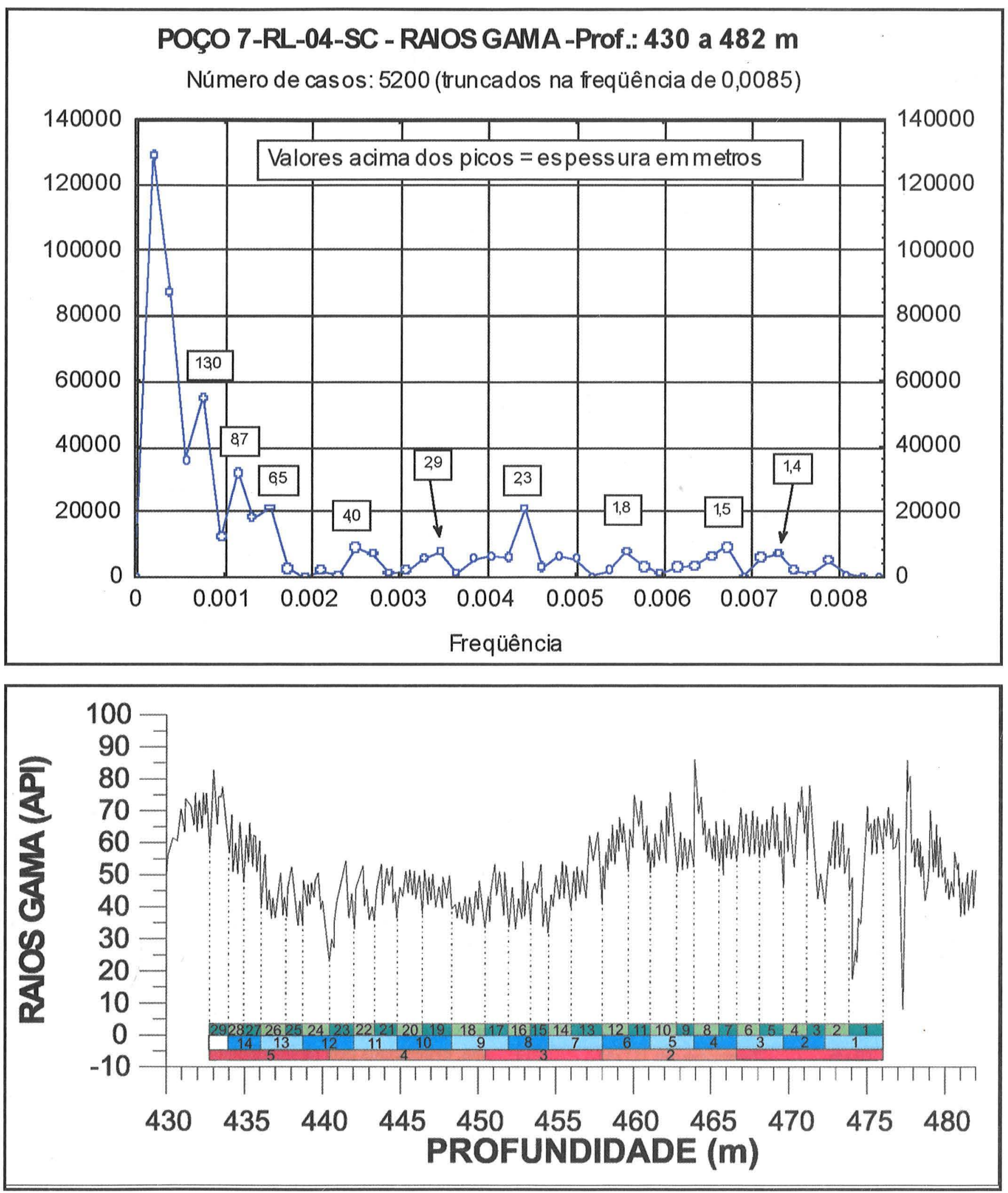

Figura 12 - Periodograma (A) e perfil de raios gama (B) do trecho entre 430 e $482 \mathrm{~m}$ do poço 7-RL-04-SC. O eixo "Valores do Periodograma" da figura (A) pode ser interpretado como a variância da série temporal para cada freqüencia. Os periodos encontrados pelo programa Periodo (ver texto) estão marcados e numerados, da base para o topo, no perfil: precessão, em verde; obliqüidade, em azul; excentricidade curta, em vermelho. 


\begin{tabular}{|c|c|c|}
\hline 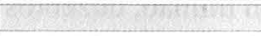 & \multicolumn{2}{|c|}{ ESPESSURAS (m) } \\
\hline FREQÜENCIAS BAIXAS & \multicolumn{2}{|c|}{$8,76,5$} \\
\hline FREQÜENCIAS MÉDIAS & $4,0 \quad 2,9^{\prime \prime} \quad 2,3$ & \\
\hline FREQÜÊNCIAS ALTAS & \multicolumn{2}{|c|}{ 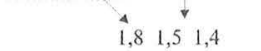 } \\
\hline
\end{tabular}

Figura 13 - Espessuras encontradas no intervalo de 430 a 482 $m$ no perfil de raios gama do poço 7-RL-04-SC, de acordo com o periodograma, e a relação entre elas.

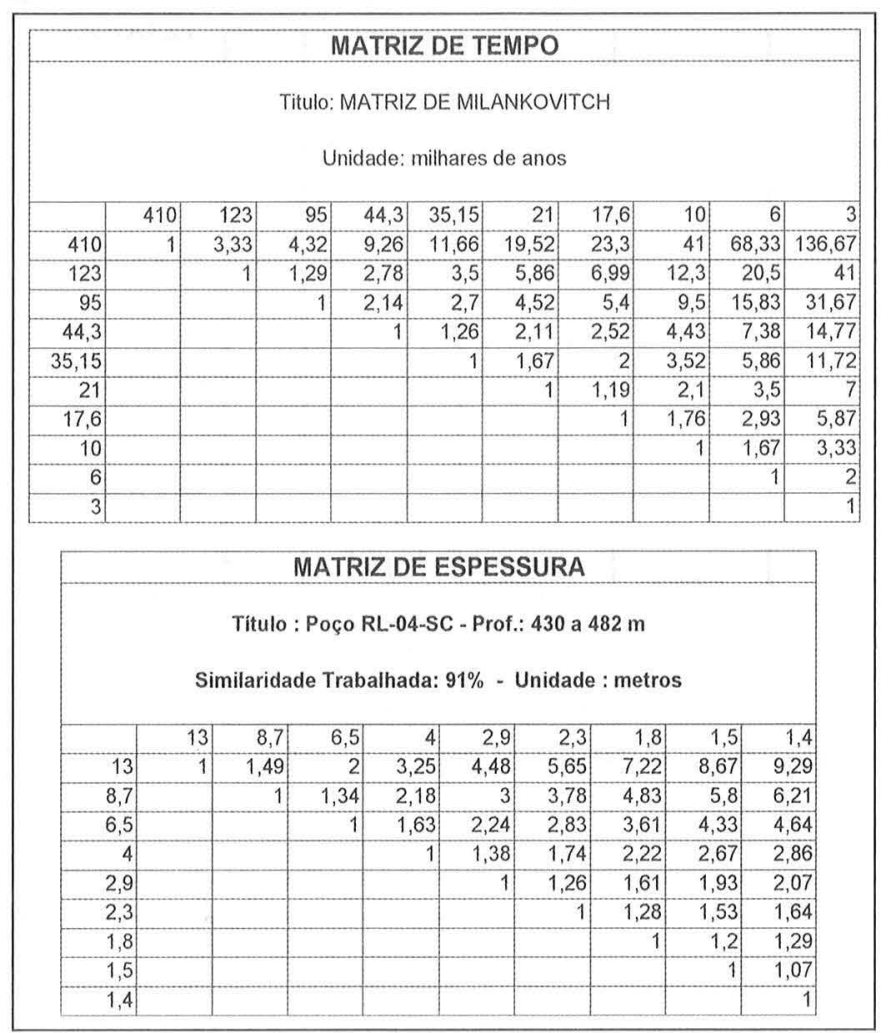

Figura 14 - Matrizes de tempo e espessura do intervalo entre 430 e 482 m do perfil de raios gama do poço 7-RL-04-ES.

Tabela 6 - Espessuras e períodos correspondentes de Milankovitch para o intervalo entre 430 e $482 \mathrm{~m}$ do poço 7-RL-04-SC.

\begin{tabular}{|c|c|c|c|}
\hline $\begin{array}{l}\text { Espessuras } \\
\text { no perfil } \\
\text { (m) }\end{array}$ & $\begin{array}{c}\text { Períodos } \\
\text { correspondentes } \\
\text { (mil anos) }\end{array}$ & $\begin{array}{c}\text { Ciclo } \\
\text { de } \\
\text { Milankovitch }\end{array}$ & $\begin{array}{c}\text { Taxas de } \\
\text { acumulação } \\
\text { (cm/ka) }\end{array}$ \\
\hline 8,7 e 6,5 & 123 a 95 & Excentricidade curta & 5,3 a 9,2 \\
\hline 4,0 & \multirow{3}{*}{44,3 a 35,5} & \multirow{3}{*}{ Obliqüidade } & \multirow{3}{*}{5,2 a 9,0} \\
\hline 2,9 & & & \\
\hline 2,3 & & & \\
\hline 1,8 & \multirow{3}{*}{21 a 17,6} & \multirow{3}{*}{ Precessão } & \multirow{3}{*}{6,7 a 8,5} \\
\hline 1,5 & & & \\
\hline 1,4 & & & \\
\hline
\end{tabular}

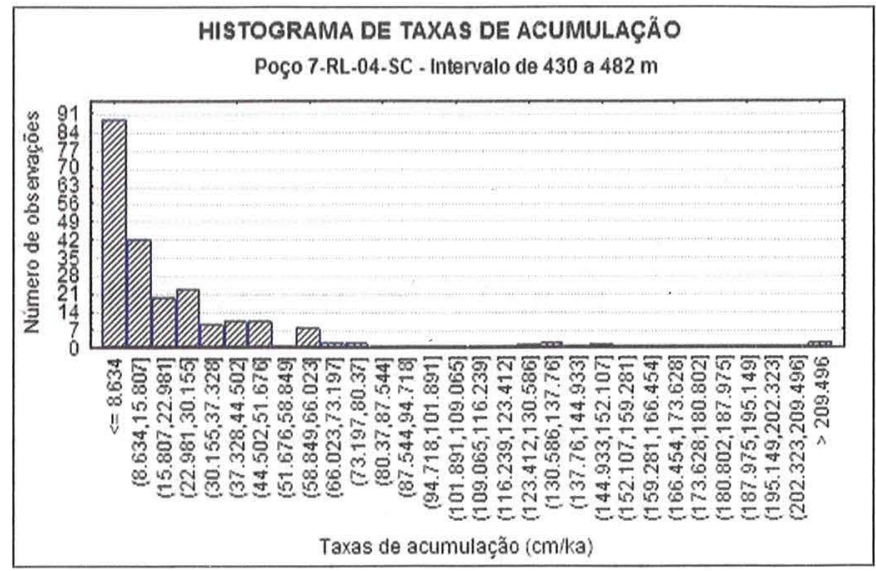

Figura 15 - Histograma das taxas de acumulação para o poço 7 RL-04-SC, no intervalo entre 430 e $482 \mathrm{~m}$. As taxas mais freqüentes são as abaixo de $8,6 \mathrm{~cm} / \mathrm{ka}$.

de acumulação registradas nos depósitos glaciais e interglaciais do hemisfério norte. Em sedimentos marinhos e plataformais, as taxas de períodos interglaciais variam entre 1 e $5 \mathrm{~cm} / \mathrm{ka}$, enquanto que as de épocas glaciais aumentam para mais de $10 \mathrm{~cm} /$ ka (Elverhfi \& Henrich 1996). Esses valores estão de acordo com aqueles encontrados na análise dos perfis $(5,2$ a 9,3 cm/ka, com médias de 7,4 a $8,4 \mathrm{~cm} / \mathrm{ka}$ ).

Outros autores fizeram estudos cicloestratigráficos na Bacia do Paraná, porém para uma seção muito maior, desde o Grupo Itararé até a Formação Irati. Esse intervalo representa um período de deposição de aproximadamente 30 milhões de anos, do Asseliano ao Kazaniano (Daemon \& Quadros 1970). Os resultados foram publicados por Chaves et al. (1994 e 1995). As regiões trabalhadas foram as de Figueira-Sapopema, no Estado do Paraná, e de Candiota, no sul do Estado do Rio Grande do Sul. Os autores identificaram ciclos de engrossamento e afinamento para o topo em afloramento e em perfis de raios gama e de resistividade, os quais, a partir de análise espectral e da construção de Diagramas de Fischer, associaram aos ciclos de excentricidade longa (400 mil anos) e curta (100 mil anos). O tempo total de deposição foi de 7,8 e 8,0 milhões de anos para as seções do Paraná e do Rio Grande do Sul, respectivamente. Porém, como não determinaram os tempos relativos a cada unidade em separado, não é possível fazer uma correlação entre os dados obtidos no nosso trabalho com os do Grupo Itararé alcançados pelos autores.

Poço IB-93-RS A análise do perfil de raios gama desse poço apresentou problemas desde o início, pois não era possível encontrar intervalos com as características de uma onda estacionária. Os ritmos são muito pouco espessos para representar variações da ordem dos ciclos orbitais, considerando-se o ambiente de deposição, e a variação na taxa de acumulação é muito alta, evidenciada pela rápida diminuição da espessura dos pares em direção ao topo da seção.

Sendo assim, partiu-se para a análise do testemunho, o qual apresentou a mesma ciclicidade presente naquele do poço 7-RL04-SC. Essa evidência modificou o enfoque da procura pelos ciclos. Foi feita então a contagem dos pares de ritmos no testemunho, a qual, mostrou a existência de cerca de 561 pares. Como será visto a seguir, esse número representa um tempo de 12342 anos, ou seja, aproximadamente a metade de um ciclo de precessão. Logo, não seria possível, realmente, encontrar vários ciclos orbitais no perfil. 


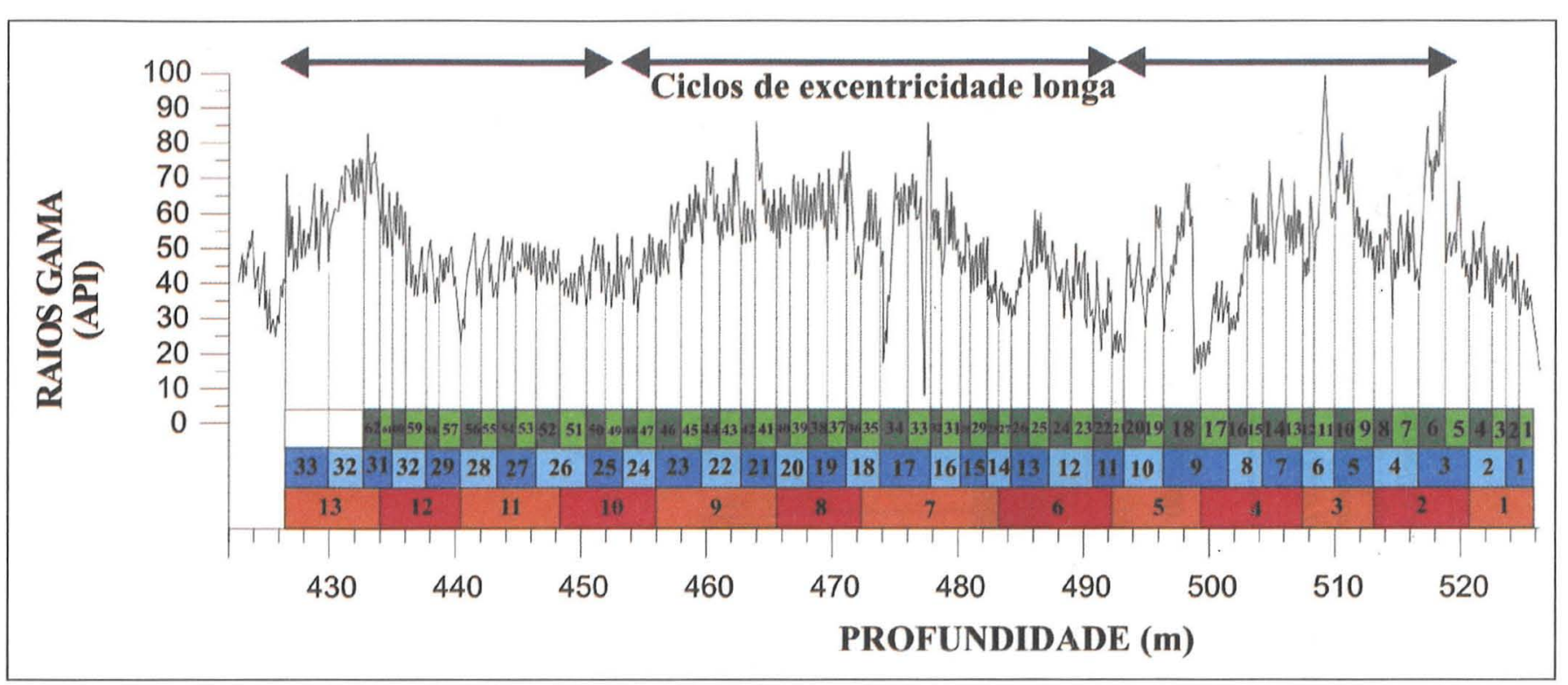

Figura 16- Perfil de raios gama do poço 7-RL-04-SC, mostrando a interpretação final dos ciclos orbitais. Os ciclos de excentricidade curta estão em vermelho e laranja, os de obliqüidade em azul e os de precessão em verde. Os dois últimos ciclos de obliqüidade (32 e 33) e o último de excentricidade (13) referem-se ao trecho onde não foi realizada a análise (vide texto para explicação). As setas de cor azul escura representam a ciclicidade devida aos ciclos de excentricidade longa, interpretados após a análise do perfil. O tempo aproximado de deposição foi de 1 milhão, 254 mil anos no total.

Análise dos testemunhos Os intervalos escaneados dos testemunhos dos dois poços foram analisados da mesma forma que os perfis de raios gama.

As lâminas rítmicas são descritas na literatura como varvitos ou de aspecto várvico (Marques-Toigo et al. 1989, Machado 1989, Castro 1991 e 1995, Machado 1994, Castro \& Schneider 1993, Holz 1995, Santos et al. 1996, Silveira 2000). Sendo assim, a matriz utilizada foi escolhida dentro dessa ordem temporal, ou seja, entre anos e séculos.

Foram feitos vários testes com diversas possibilidades de ciclos para a matriz de tempo. As primeiras matrizes utilizadas, contemplando o ciclo anual como o de mais alta freqüência, não produziram resultados satisfatórios, fornecendo taxas de acumulação altíssimas, entre 3 e $6 \mathrm{~m} / \mathrm{ka}$, para os ciclos básicos representados pelos pares de ritmos $(1 \mathrm{par}=1 \mathrm{ano})$.

Mudou-se então a abordagem para os ciclos solares. Sua variabilidade nos dados terrestres é muito grande (tabela III.4), e foram necessárias várias tentativas para se chegar a resultados coerentes em termos de taxas de acumulação e correlação entre as diversas freqüências. A solução apareceu com o ciclo de 22 anos na alta freqüência.

A matriz final observou os seguintes parâmetros: as médias dos períodos encontrados na literatura (tabela III.4) e as ordens citadas por Bucha \& Bucha Jr. (1998). Os valores finais escolhidos para os períodos foram: 22, 50, 80, 100, 150, 180, 280, 650,750 e 1000 anos. A limitação em dez valores é do programa Período. Para os dados de espessura, a limitação do programa é de quinze.

Poço 7-RL-04-SC As espessuras referidas nesse item são as originais e não as corrigidas utilizadas na análise do perfil de raios gama. As espessuras serão igualadas durante a análise conjunta dos dados de testemunho e perfil.

A análise do testemunho foi dividida em dois intervalos, devido à pequena falha existente entre os dois.

Intervalo de $\mathbf{5 2 6 , 7 0}$ a $\mathbf{5 2 5 , 8 9} \mathbf{m} \quad$ O intervalo em questão tem $81 \mathrm{~cm}$, mas nem todo ele possui as qualidades de uma sé- rie estacionária. A porção inferior apresenta uma variação muito grande em termos de espessuras. Por isso, só foi utilizado para a análise o trecho entre 526,27 e $525,89 \mathrm{~m}$. Os resultados foram interpretados para todo o comprimento do intervalo.

Quando se trabalha com testemunhos, a dispersão apresentada pelos picos no periodograma devido às variações na taxa de acumulação, é maior, pois os períodos de tempo em questão são muito menores, implicando em taxas mais variáveis proporcionalmente.

O periodograma do intervalo mostra bem essa dispersão (figura 17), que não afeta, porém, a identificação dos picos mais representativos.

As relações entre as diferentes freqüências foram analisadas no gráfico de escala de cinza da mesma forma que aquelas dos perfis de raios gama e apresentaram-se sob a forma de pares de ritmos, dois pares e feixes assimétricos com espessura aumentando para o topo. Os últimos podem conter, à medida que a freqüência diminui, três a cinco, seis a dez, onze a quinze e vinte e nove a trinta e nove pares de ritmos. A figura 18 dá a relação entre as diversas ordens de pares e feixes.

Poço IB-93-RS A análise do perfil de raios gama desse poço apresentou problemas desde o início, pois não era possivel encontrar intervalos com as características de uma onda estacionária. Os ritmos são muito pouco espessos para representar variações da ordem dos ciclos orbitais, considerando-se o ambiente de deposição, e a variação na taxa de acumulação é muito alta, evidenciada pela rápida diminuição da espessura dos pares em direção ao topo da seção.

Sendo assim, partiu-se para a análise do testemunho, o qual apresentou a mesma ciclicidade presente naquele do poço 7-RL04-SC. Essa evidência modificou o enfoque da procura pelos ciclos. Foi feita então a contagem dos pares de ritmos no testemunho, a qual, mostrou a existência de cerca de 561 pares. Como será visto a seguir, esse número representa um tempo de 12342 anos, ou seja, aproximadamente a metade de um ciclo de precessão. Logo, não seria possível, realmente, encontrar vários ciclos orbitais no perfil. 


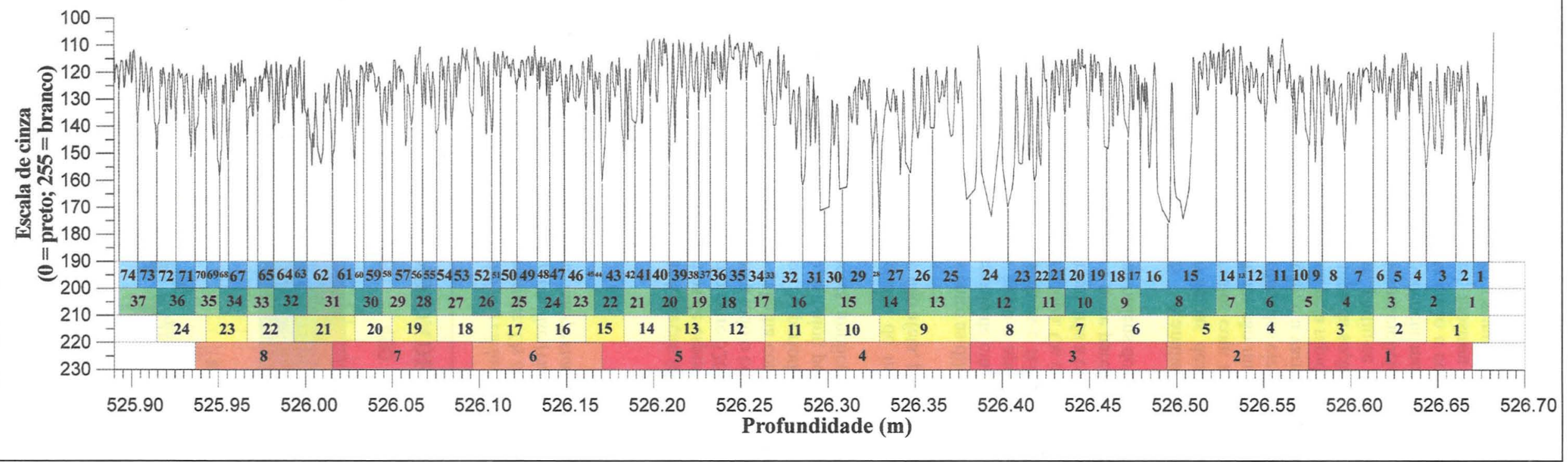

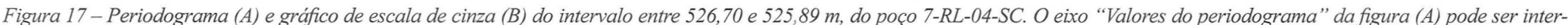

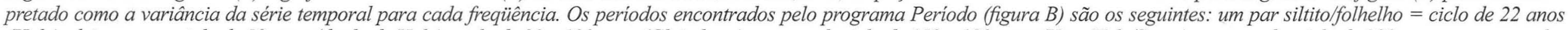

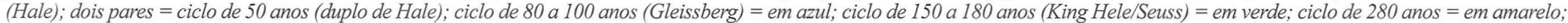
ciclo de 650 a 1000 anos = em vermelho e laranja. 
Análise dos testemunhos Os intervalos escaneados dos testemunhos dos dois poços foram analisados da mesma forma que os perfis de raios gama.

As lâminas rítmicas são descritas na literatura como varvitos ou de aspecto várvico (Marques-Toigo et al. 1989, Machado 1989, Castro 1991 e 1995, Machado 1994, Castro \& Schneider 1993, Holz 1995, Santos et al. 1996, Silveira 2000). Sendo assim, a matriz utilizada foi escolhida dentro dessa ordem temporal, ou seja, entre anos e séculos.

Foram feitos vários testes com diversas possibilidades de ciclos para a matriz de tempo. As primeiras matrizes utilizadas, contemplando o ciclo anual como o de mais alta freqüência, não produziram resultados satisfatórios, fornecendo taxas de acumulação altíssimas, entre 3 e $6 \mathrm{~m} / \mathrm{ka}$, para os ciclos básicos representados pelos pares de ritmos ( 1 par $=1$ ano).

Mudou-se então a abordagem para os ciclos solares. Sua variabilidade nos dados terrestres é muito grande (tabela III.4), e foram necessárias várias tentativas para se chegar a resultados coerentes em termos de taxas de acumulação e correlação entre as diversas freqüências. A solução apareceu com o ciclo de 22 anos na alta freqüência.

A matriz final observou os seguintes parâmetros: as médias dos períodos encontrados na literatura (tabela III.4) e as ordens citadas por Bucha \& Bucha Jr. (1998). Os valores finais escolhidos para os períodos foram: $22,50,80,100,150,180,280$, 650,750 e 1000 anos. A limitação em dez valores é do programa Período. Para os dados de espessura, a limitação do programa é de quinze.

Poço 7-RL-04-SC As espessuras referidas nesse item são as originais e não as corrigidas utilizadas na análise do perfil de raios gama. As espessuras serão igualadas durante a análise conjunta dos dados de testemunho e perfil.

A análise do testemunho foi dividida em dois intervalos, devido à pequena falha existente entre os dois.

Intervalo de 526,70 a $525,89 \mathrm{~m}$ O intervalo em questão tem $81 \mathrm{~cm}$, mas nem todo ele possui as qualidades de uma série estacionária. A porção inferior apresenta uma variação muito grande em termos de espessuras. Por isso, só foi utilizado para a análise o trecho entre 526,27 e $525,89 \mathrm{~m}$. Os resultados foram interpretados para todo o comprimento do intervalo.

Quando se trabalha com testemunhos, a dispersão apresentada pelos picos no periodograma devido às variações na taxa de acumulação, é maior, pois os períodos de tempo em questão são muito menores, implicando em taxas mais variáveis proporcionalmente.

O periodograma do intervalo mostra bem essa dispersão (figura 17), que não afeta, porém, a identificação dos picos mais representativos.

As relações entre as diferentes frequiências foram analisadas no gráfico de escala de cinza da mesma forma que aquelas dos perfis de raios gama e apresentaram-se sob a forma de pares de ritmos, dois pares e feixes assimétricos com espessura aumentando para o topo. Os últimos podem conter, à medida que a freqüência diminui, três a cinco, seis a dez, onze a quinze e vinte e nove a trinta e nove pares de ritmos. A figura 18 dá a relação entre as diversas ordens de pares e feixes.

Como estamos lidando com periodicidades de altíssima freqüência, alterações no influxo sedimentar, causando maior descarga de sedimentos de granulação relativamente mais grossa durante um ciclo básico de 1 par, como areia muito fina na base dos pares, podem fazer com que dentro de um ciclo de mais baixa freqüência apareçam algumas feições que confundem o padrão de espessamento para o topo, devido a engrossamento

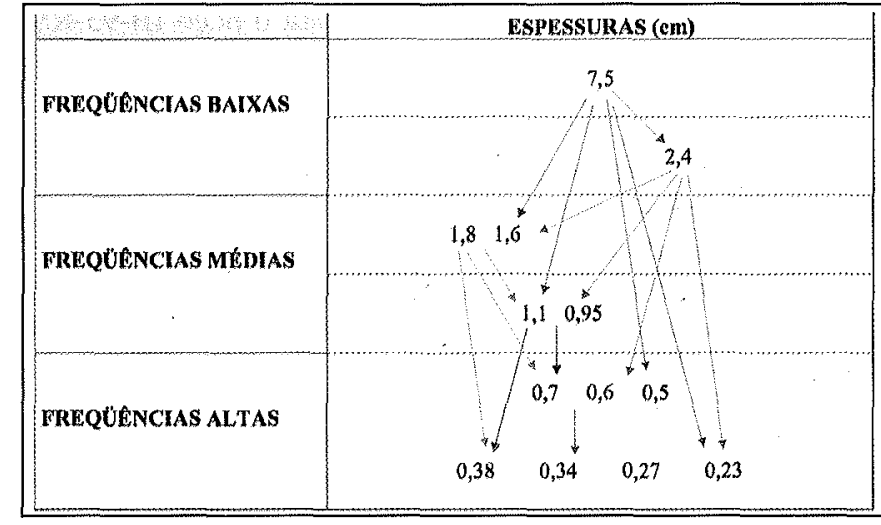

Figura 18 - Espessuras encontradas no intervalo de 526,70 a 525,89 m no gráfico de escala de cinza do poço 7-RL-04-SC, de acordo com o periodograma, e a relação entre elas.

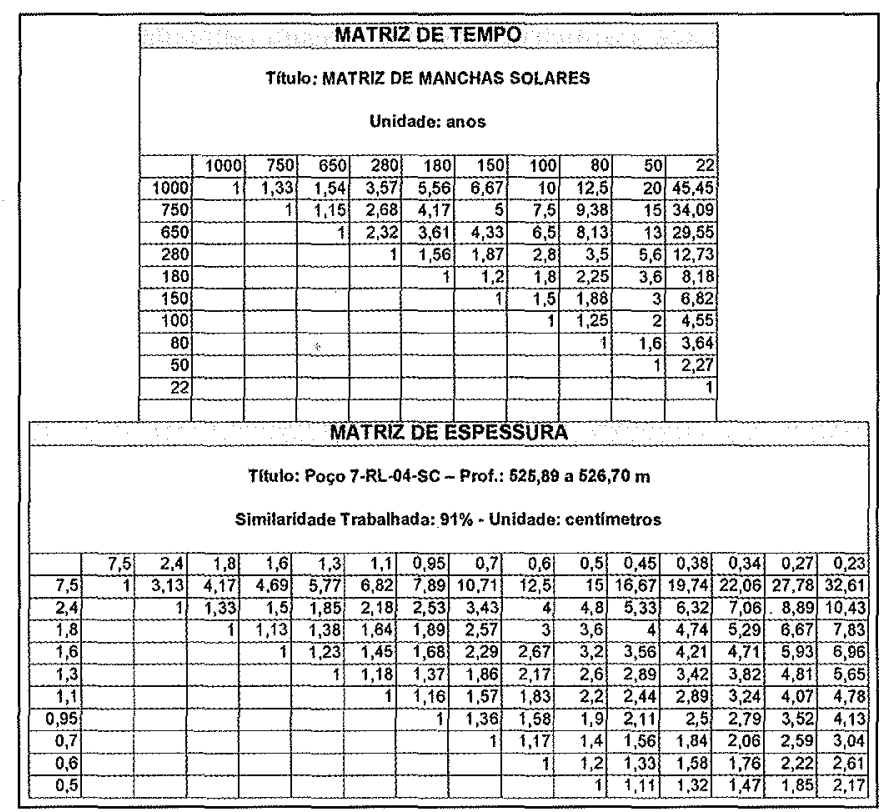

Figura 19 - Matrizes de tempo e espessura do intervalo entre 526,70 e 525,89 $m$ do gráfico de escala de cinza do poço 7-RL04-SC.

eventual. Isso gerou picos mais claros no gráfico, devido à maior intensidade de luz reffetida pelos grãos de quartzo. $O$ importante é observar a tendência ao espessamento, que revela e caracteriza os ciclos individualmente.

As matrizes de tempo e espessura utilizadas estão apresentados na figura 19 (similaridade de 91\%). Os pares espessura-tempo correlacionados estão listados na tabela 7. Observando-se essa última tabela, nota-se que a espessura de $0,45 \mathrm{~cm}$, presente no periodograma, está ausente. Apesar da mesma ter certa identificação com o ciclo de 50 anos, não apresentou muita relação com as demais. A espessura de $18,7 \mathrm{~cm}$ é um harmônico do comprimento total do intervalo.

Devido à grande variabilidade das taxas de acumulação, algumas espessuras mostraram-se presentes em mais de um ciclo, como as de 0,38 a $0,34 \mathrm{~cm}$, que além dos ciclos de 22 anos também representam os de 50 anos, que se relacionam com os ciclos de 80 a 100 e 150 a 180 anos. O essencial é que a conexão entre cada um com todos os outros foi alta e que essa variabilidade não afetou a confiabilidade dos resultados, os quais se repetiram 
tanto para o próximo intervalo quanto para o poço IB-93-RS. O histograma da figura 20 é uma evidência de que as taxas de acumulação mais freqüentes são as que correspondem aos resultados interpretados.

Certos ciclos presentes não contêm o número de pares mínimo, como acontece com alguns dos de Gleissberg (dois ao invés de três), revelando diminutos hiatos na deposição. Essas interrupções no registro sedimentar não invalidam a análise, mas provocam modulações na freqüência, atenuando os picos de período curto (Schwarzacher 1989).

Multiplicando-se o número de pares (250) pelo período médio do ciclo de Hale (22 anos), conclui-se que o mesmo foi depositado em cerca de 5500 anos, a uma taxa média de 14,6 $\mathrm{cm} / \mathrm{ka}$. O aumento na taxa é um reflexo das maiores espessuras no trecho inferior do intervalo.

Intervalo de $\mathbf{5 2 5 , 8 7}$ a $\mathbf{5 2 5 , 4 7} \mathbf{m} \quad$ O periodograma do intervalo mostra uma dispersão menor que o anterior, com espessuras bem semelhantes (figura 21). A relação entre elas está exibida na figura 22 e é também marcada pelo agrupamento de pares em dois e em feixes assimétricos com espessura aumentando para o topo. O número de pares por feixe varia da mesma forma que para o intervalo anterior. As matrizes de espessura e de tempo estão apresentadas na figura 23 e os pares finais espessura-tempo na tabela 8 (índice de similaridade de $91 \%$. Para os pares espessura-tempo escolhidos, o índice varia de $91 \%$ a 99\%, com modas em 93\%)

A partir da tabela 8 citada pode-se verificar a coerência dos resultados dos dois intervalos. Ambos possuem a mesma ciclicidade e a semelhança nas espessuras ajuda a confirmar os valores de taxa de acumulação previamente encontrados. A espessura de $0,40 \mathrm{~cm}$ não apresentou muita relação com as demais.

A variabilidade das taxas de acumulação, da mesma forma que no intervalo anterior, fez com que algumas espessuras representassem mais de um ciclo. Foi o caso das espessuras de 0,37 e $0,35 \mathrm{~cm}$, marcando os ciclos de 22 anos ou os de 50 anos. As espessuras de 3,9 e 0,47 cm são harmônicos de outros períodos. O histograma da figura 24 apresenta as taxas mais freqüentes encontradas.

Pequenos hiatos também estão presentes, revelados pelas espessuras de alguns ciclos de Gleissberg, inferiores às médias apresentadas pelo periodograma, porém em menor quantidade que no intervalo inferior.

A deposição dos ritmitos do intervalo foi concluída ao longo de aproximadamente 3608 anos (164 pares vezes 22 anos), a uma taxa de acumulação média de $11,4 \mathrm{~cm} / \mathrm{ka}$.

A figura 25 mostra todo o comprimento escaneado do testemunho, com os dois intervalos, e a interpretação final da ciclicidade. O tempo total calculado foi de 9108 anos.

Pode-se fazer uma estimativa da espessura do rejeito da pequena falha entre os dois intervalos escaneados e assim ter uma idéia do tempo total envolvido na deposição. Considerando a relação entre os ciclos de 650 a 1000 anos com os de Gleissberg (1 para 9 ou 10) e observando o trecho superior do primeiro intervalo e o inferior do segundo, nota-se que existem entre ambos (entre os ciclos 8 e 9 de baixa freqüência) 6 ciclos de Gleissberg calculados.

Verifica-se que faltam, portanto, 3 ou 4 ciclos de Gleisberg para formar o de baixa freqüência entre os dois intervalos. Como a espessura média desse ciclo no gráfico é de $1 \mathrm{~cm}$ e o espaço entre os intervalos é de $3 \mathrm{~cm}$, conclui-se que o rejeito da falha deve ser no máximo de $1 \mathrm{~cm}$. Multiplicando os 3 ou $4 \mathrm{~cm}$ que faltam pelo período médio do ciclo de Gleissberg ( 90 anos), obtém-se um tempo de 270 ou 360 anos. Somando-se esses valores ao obtido na análise, chega-se a um tempo total de deposição entre 9378 e 9468 anos (figura 25).
Tabela 7 - Espessuras e periodos correspondentes dos ciclos solares para o intervalo entre 526,27 a 525,89 m do testemunho do poço 7-RL-04-SC.

\begin{tabular}{|c|c|c|c|c|}
\hline & $\begin{array}{c}\text { Espessuras } \\
\text { no testemunho } \\
\text { (cm) }\end{array}$ & $\begin{array}{c}\text { Periodos } \\
\text { correspondentes } \\
\text { (anos) }\end{array}$ & Ciclo solar & $\begin{array}{c}\text { Taxas de } \\
\text { acumulação } \\
\text { (cm/ka) }\end{array}$ \\
\hline \multirow{6}{*}{ 选 } & 7,5 & 1000 a 650 & -...-- & 7,5 a 11,5 \\
\hline & 2,4 & 280 & $\ldots$ & 8,6 \\
\hline & 1,8 & \multirow[t]{2}{*}{180 a 150} & \multirow[t]{2}{*}{ King Hele e Seuss } & \multirow[t]{2}{*}{8,9 a 12} \\
\hline & 1,6 & & & \\
\hline & 1,1 & \multirow[t]{2}{*}{100 a 80} & \multirow[t]{2}{*}{ Gleissberg } & \multirow[t]{2}{*}{11,9 a 13,8} \\
\hline & 0,95 & & & \\
\hline \multirow{3}{*}{ 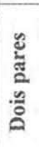 } & 0,7 & \multirow{3}{*}{50} & \multirow{3}{*}{ Duplo de Hale } & \multirow{3}{*}{10 a 14} \\
\hline & 0,6 & & & \\
\hline & 0,5 & & & \\
\hline \multirow{4}{*}{ 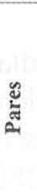 } & 0,38 & \multirow{4}{*}{22} & \multirow{4}{*}{ Hale } & \multirow{4}{*}{10,5 a 17,3} \\
\hline & 0,34 & & & \\
\hline & 0,27 & & & \\
\hline & 0,23 & & & \\
\hline
\end{tabular}

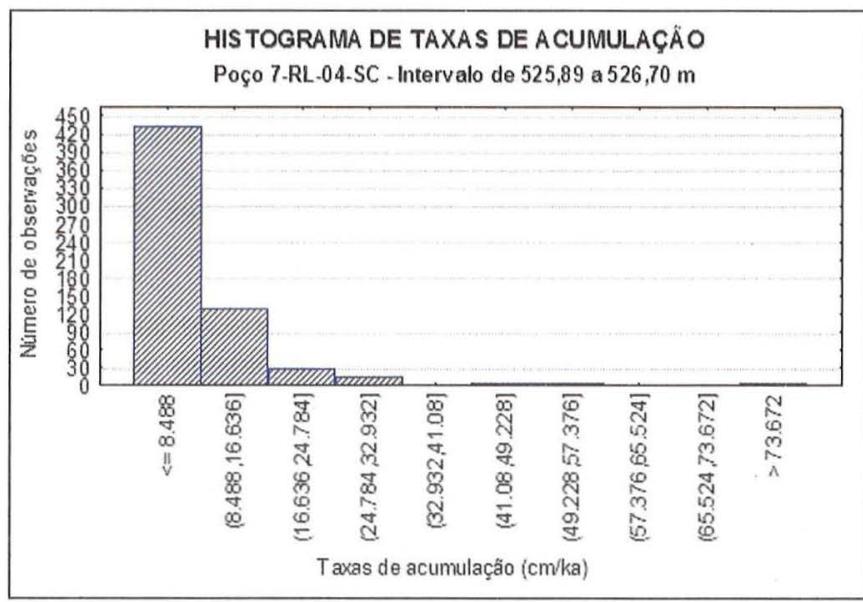

Figura 20 - Histograma das taxas de acumulação para o poço 7-RL-04-SC, no intervalo entre 525,89 e 526,70 m. As taxas mais freqüentes são as abaixo de $8,5 \mathrm{~cm} / \mathrm{ka}$.

POÇO IB-93-RS O testemunho (vide artigo CEGI-1) foi escaneado em um comprimento total de $8,32 \mathrm{~m}$. Mas, devido à grande variabilidade das taxas de acumulação, representada pela mudança rápida na espessura dos pares dos ritmos, de métricos para milimétricos em $44 \mathrm{~m}$ (334 a $290 \mathrm{~m})$, somente o intervalo superior (290,46 a 290,08 m) apresentou características comparáveis às de uma série estacionária. A descrição litológica mostrou que esse intervalo é representativo de toda a seqüência rítmica do poço. Portanto, sua análise pode ser considerada válida para toda essa seção.

Porém a variabilidade das taxas, é relativamente grande, com a espessura dos pares diminuindo de uma média de 4 para menos de 1 milímetro em $37 \mathrm{~cm}$, forçou a redução do intervalo para a análise para um trecho entre 290,23 e 290,46 m (23 cm), 


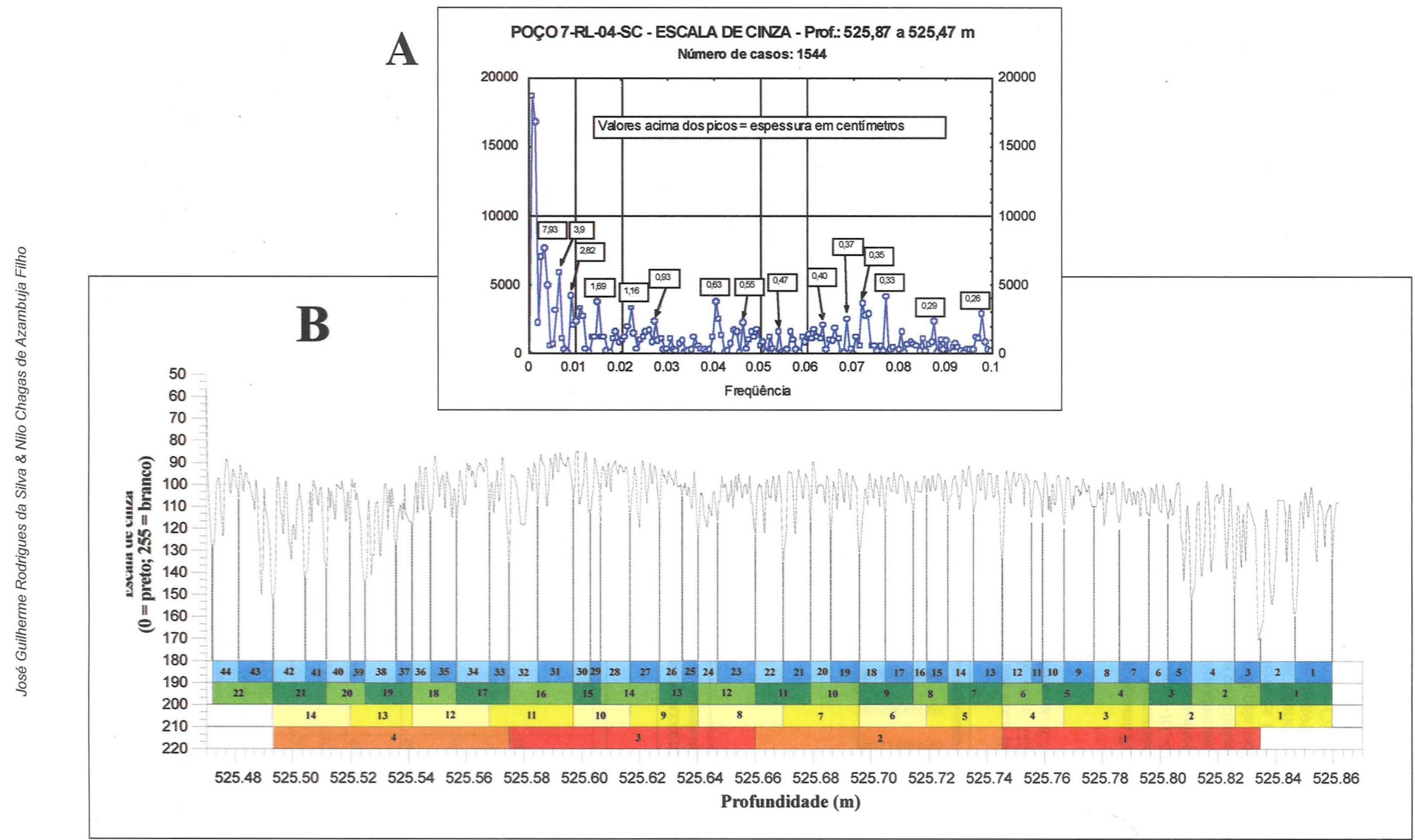

Figura 21 - Periodograma (A) e gráfico de escala de cinza (B) do intervalo entre 525,87 e 525,47 m, do poço 7-RL-04-SC. O eixo "Valores do periodograma" da figura (A) pode ser interpretado como a variância da série temporal para cada freqüência. Os periodos encontrados pelo programa Período (figura B) são os seguintes: um par siltito/folhelho = ciclo de 22 anos (Hale); dois pares = ciclo de 50 anos (duplo de Hale); ciclo de 80 a 100 anos (Gleissberg) =em azul; ciclo de 150 a 180 anos (King Hele/Seuss) =em verde; ciclo de 280 anos = em amarelo; ciclo de 650 a 1000 anos = em vermelho e laranja. 


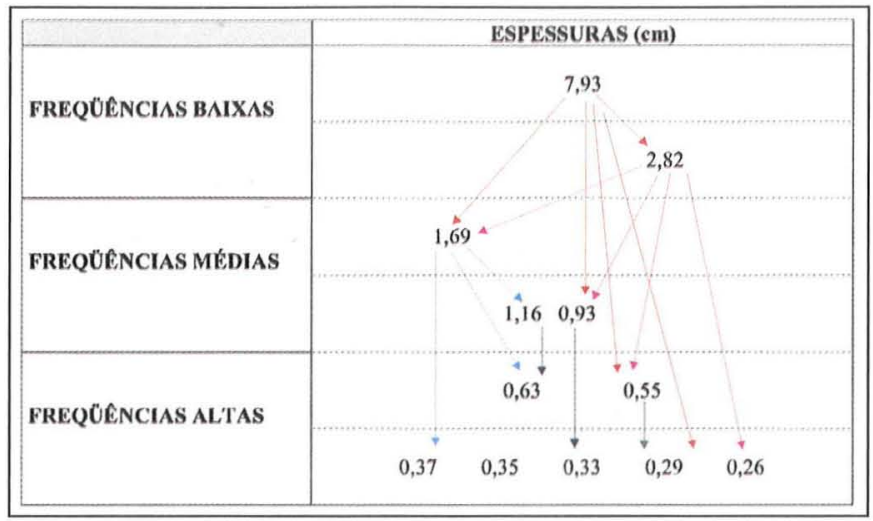

Figura 22 - Espessuras encontradas no intervalo de 525,87 a 525,47 m no gráfico de escala de cinza do poço 7-RL-04-SC, de acordo com o periodograma, e a relação entre elas.

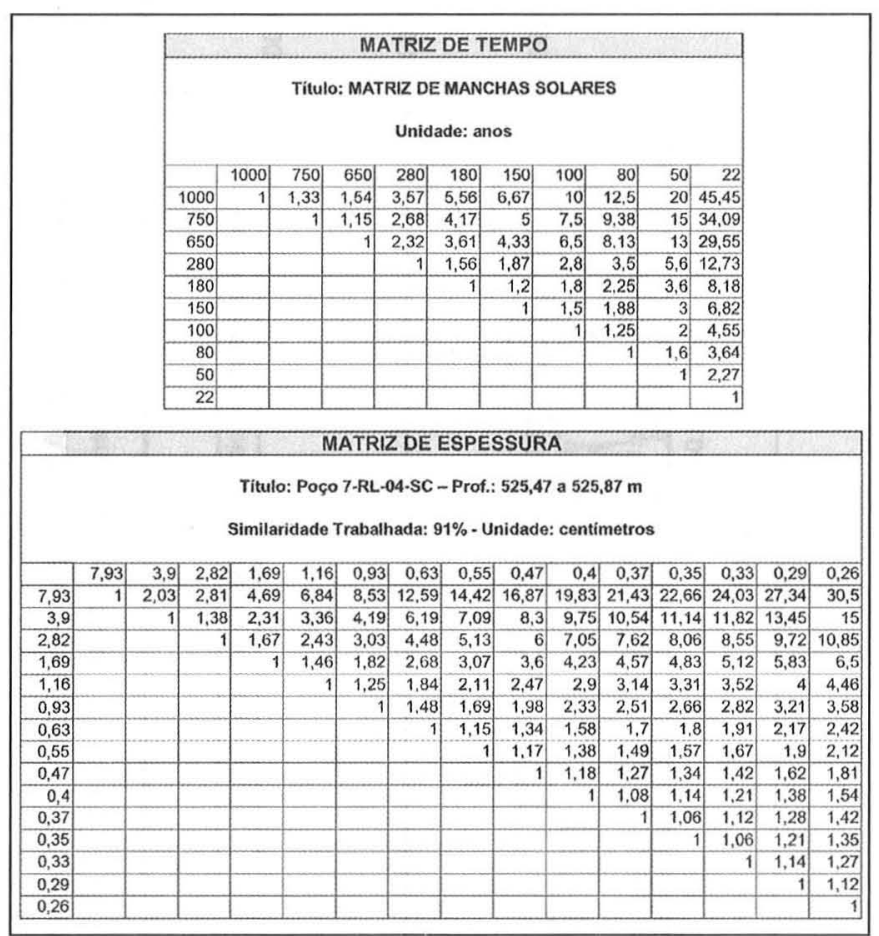

Figura 23 - Matrizes de tempo e espessura do intervalo entre 525,87 e 525,47 m do gráfico de escala de cinza do poço 7-RL04-SC.

onde as mudanças de espessura são menores. O intervalo é longo o suficiente para o estudo, pois os ciclos estão na ordem de milímetros. Da mesma forma, Ripepe et al. (1991), analisando os varvitos eocênicos da Formação Green River (EUA), utilizaram séries temporais da ordem de $3 \mathrm{a} 4 \mathrm{~cm}$, pois as lâminas dos varvitos possuíam espessura média de 0,03 $\mathrm{mm}$.

Os resultados obtidos foram interpretados para todo o intervalo, entre 290,46 e $290,08 \mathrm{~m}$.

O periodograma (figura 26) mostra uma grande dispersão dos picos de alta freqüiência e poucos picos de baixa. Essa disposição é um reflexo da variabilidade das taxas de acumulação. Sendo assim, devido à pequena quantidade de picos na baixa freqüência, foram considerados apenas dez picos para a análise.

A verificação dos valores de espessura do periodograma no gráfico de escala de cinza revelou a inter-relação entre os mes-
Tabela 8 - Espessuras e períodos correspondentes dos ciclos solares para o intervalo entre 525,87 a 525,47 m do testemunho do poço 7-RL-04-SC

\begin{tabular}{|c|c|c|c|c|}
\hline & $\begin{array}{c}\text { Espessuras } \\
\text { no testemunho } \\
\text { (cm) }\end{array}$ & $\begin{array}{c}\text { Períodos } \\
\text { correspondentes } \\
\text { (anos) }\end{array}$ & Ciclo solar & $\begin{array}{c}\text { Taxas de } \\
\text { acumulação } \\
\text { (cm/ka) }\end{array}$ \\
\hline \multirow{5}{*}{ 递 } & 7,93 & 1000 a 650 & -an- & 7,9 a 12,2 \\
\hline & 2,82 & 280 & (n).-. & 10,1 \\
\hline & 1,69 & 180 a 150 & King Hele e Seuss & 9,4 a 11,3 \\
\hline & 1,16 & \multirow[t]{2}{*}{100 a 80} & \multirow[t]{2}{*}{ Gleissberg } & \multirow[t]{2}{*}{9,3 a 14,5} \\
\hline & 0,93 & & & \\
\hline \multirow{2}{*}{ 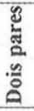 } & 0,63 & \multirow[t]{2}{*}{50} & \multirow[t]{2}{*}{ Duplo de Hale } & \multirow[t]{2}{*}{11,0 a 12,6} \\
\hline & 0,55 & & & \\
\hline \multirow{5}{*}{ 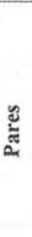 } & 0,37 & \multirow{5}{*}{22} & \multirow{5}{*}{ Hale } & \multirow{5}{*}{11,8 a 15,9} \\
\hline & 0,35 & & & \\
\hline & 0,33 & & & \\
\hline & 0,29 & & & \\
\hline & 0,26 & & & \\
\hline
\end{tabular}

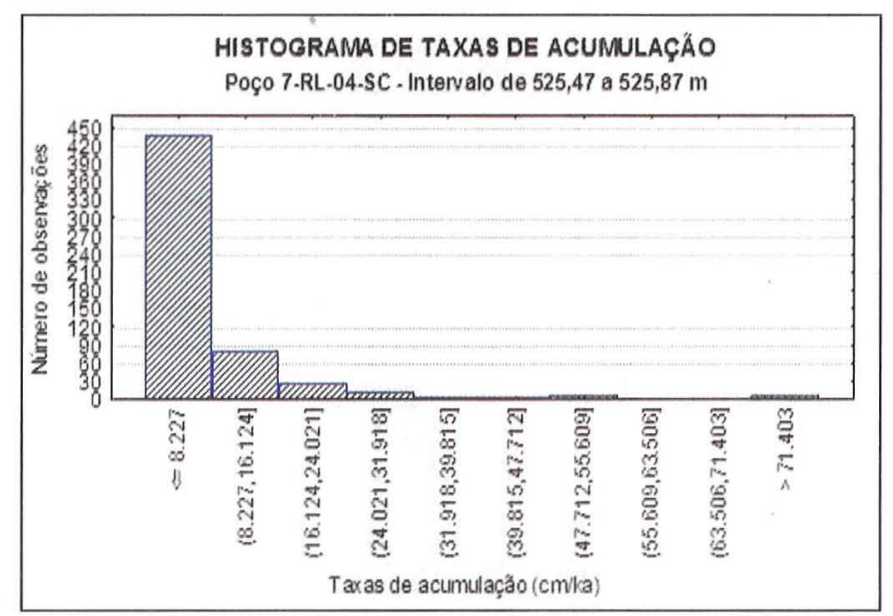

Figura 24 - Histograma das taxas de acumulação para o poço 7-RL-04-SC, no intervalo entre 525,47 e 525,87 m. As taxas mais freqüentes são as abaixo de $8,2 \mathrm{~cm} / \mathrm{ka}$.

mos (figura 27).

Após a aplicação do programa Período, foram identificados os pares espessura-tempo. As matrizes utilizadas estão na figura 28. Comparando com o poço 7-RL-04-SC, nem todas as periodicidades observadas estão presentes. Isso reflete a variação na taxa de acumulação e, naturalmente, a pequena quantidade de ciclos de baixa freqüência caracterizados no periodograma.

Outro problema causado pela variabilidade das taxas é que a correlação entre as diferentes freqüências foi menor que as encontradas nos intervalos anteriores, sendo necessário utilizar um índice de similaridade de $89 \%$. Esse índice é comparável, por exemplo, ao utilizado por Cottle (1989) em seu estudo de ciclicidade orbital no Chalk do sudeste da Inglaterra.

Os índices de similaridade dos pares espessura-tempo encontrados ficaram entre $89 \%$ e $100 \%$, com modas em $91 \%$ e $93 \%$. As espessuras e os períodos correspondentes que apresen- 


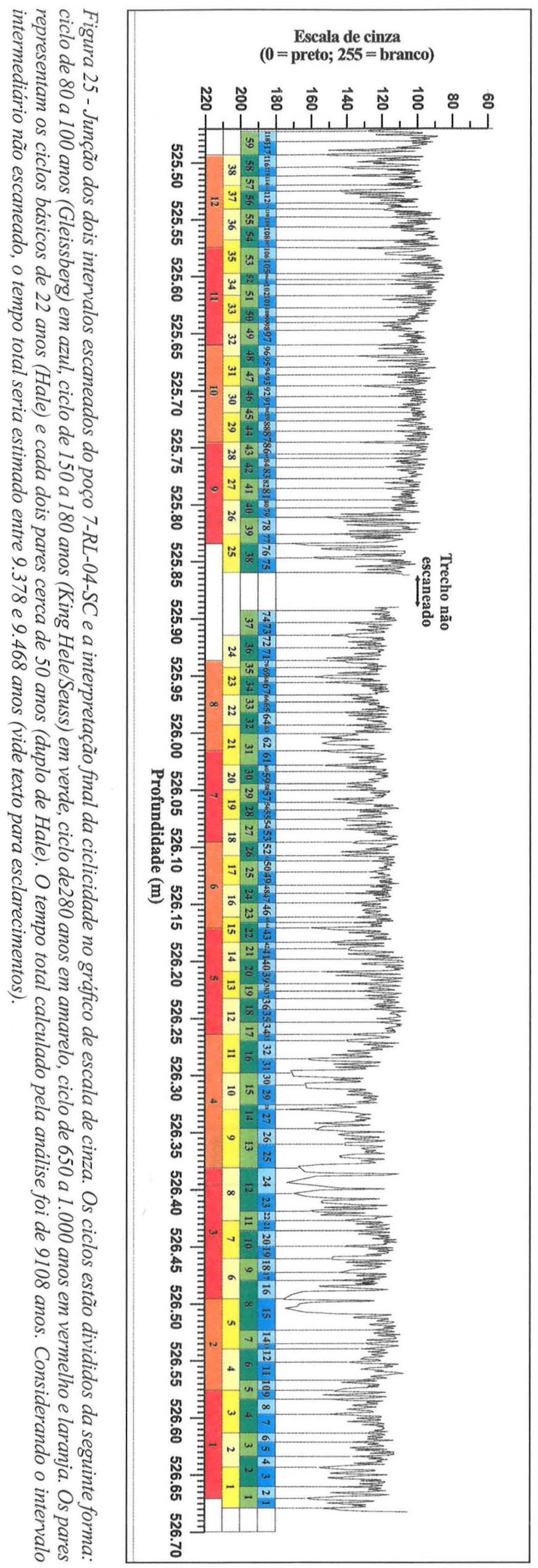

taram maior correlação estão listados na tabela 9.

As lâminas de siltito do poço IB-93-RS são marcadas por pequenos aumentos na proporção de argilominerais, que representam uma gradação normal interna. Essas mudanças composicionais geram picos no gráfico de escala de cinza, mais escuros e de mais alta freqüência que aqueles das lâminas. Quando observados na seção do poço, foi imaginado que poderiam representar alguma periodicidade interna às lâminas de siltito, como variações sazonais ou anuais, e que estariam representados no periodograma pelos picos de alta freqüência menores que $0,14 \mathrm{~cm}$. Porém, após diversas tentativas de inserir os mesmos em alguma periodicidade menor que 22 anos, concluiu-se que refletem apenas as variações na taxa de acumulação, sendo o registro da ciclicidade dos pares de lâminas com espessura muito pequena. Dessa forma, as freqüências apresentadas no periodograma, relativas a espessuras de 0,11 a $0,35 \mathrm{~cm}$, representam o ciclo solar de 22 (Hale). Algumas espessuras maiores e relativas a esse ciclo, como as de 1,25 e $0,5 \mathrm{~cm}$, não apareceram no periodograma, pois têm caráter incidental. Devido a essa dificuldade na identificação das lâminas de siltito no gráfico de escala de cinza, os pares individuais estão marcados na figura 26 para facilitar sua visualização, até a profundidade onde cada espaço entre dois picos representa um par (aproximadamente 290,14 m).

O histograma das taxas de acumulação mostra que, apesar de terem sido descobertos menos ciclos, esses estão de acordo com as taxas mais freqüentes do intervalo, corroborando a análise (figura 29).

Como toda a seção de ritmitos (334 a 290 m), da base para o topo, representa turbiditos de baixa densidade, cuja diferença de espessura reflete o distanciamento da área fonte (Silveira 2000, artigo CEGI-1), cada par pode ser interpretado como proveniente de um mesmo tipo de fluxo. As taxas de acumulação são mais altas nas posições proximais (base do testemunho) e menores nas mais distais, sendo os pares do topo provenientes de fluxos semelhantes aos da base da seção, porém sedimentados em lâmina d'água mais profunda. Logo, a ciclicidade observada no intervalo pode ser interpretada como presente em toda a seqüência rítmica. Contando o número de pares existentes da base até o topo, chega-se à quantidade de 561. Multiplicando-se esse valor por 22 (ciclo de Hale), tem-se que o intervalo foi depositado em aproximadamente 12342 anos. Esse tempo corresponde mais ou menos à metade de um ciclo de precessão.

A taxa de acumulação média para o intervalo é de $8,7 \mathrm{~cm} / \mathrm{ka}$. Para toda seqüência rítmica (334 a $290 \mathrm{~m}$ ) é de 3,6 m/ka, evidenciando as altas taxas da porção basal e a grande variabilidade comentada.

\section{DISCUSSÃO E CONCLUSÕES}

Taxas de acumulação e tempos de deposição Talvez as duas maiores incógnitas em geologia sejam precisamente o que a cicloestratigrafia se propõe a discutir: as taxas de acumulação e o tempo de deposição de uma dada seção estratigráfica. Esses dois parâmetros não invocam valores absolutos. Pelo contrário, são relativos ao comprimento da seção ou ao tempo de observação, este último ligado a medições de fenômenos geológicos observados em tempo real (Kukal 1990). A taxa de acumulação é inversamente proporcional ao tempo de deposição e esse aumenta proporcionalmente ao comprimento da seção. Logo, seções espessas, com um tempo de deposição intrinsecamente longo, apresentarão uma taxa menor que intervalos pequenos da mesma seção. Essas considerações nos conduzem aos dados obtidos nos dois poços estudados.

No poço 7-RL-04-SC nota-se no perfil de raios gama que os trechos de folhelho foram depositados em mais tempo em relação aos de ritmitos, como era de se esperar. Os 12 m de 

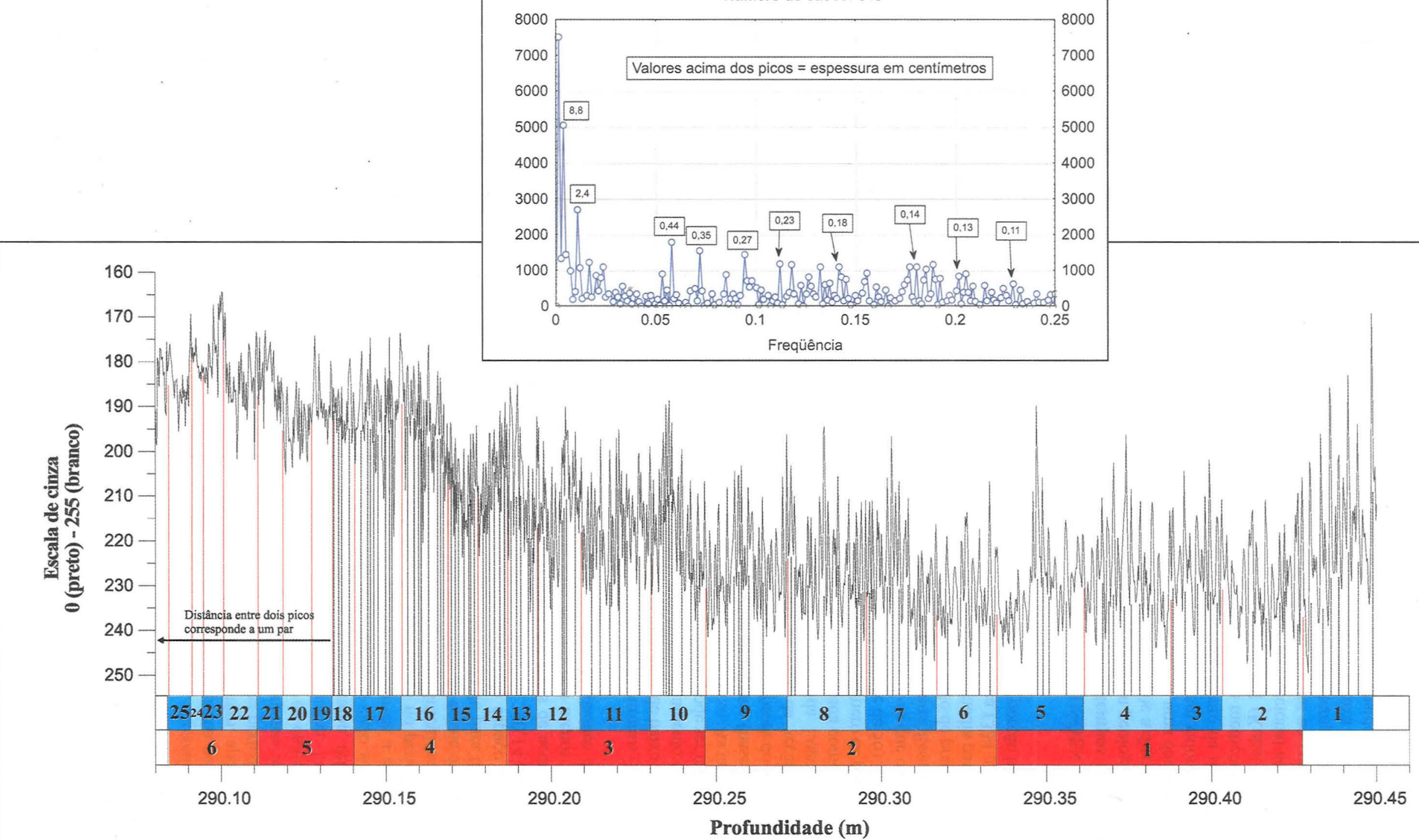

Figura 26 - Periodograma (A) e gráfico de escala de cinza (B) do intervalo entre 290,23 a 290,46 m, do poço IB-93-RS. O eixo "Valores do periodograma" da figura (A) pode ser interpretado como a variância da série temporal para cada frequiência. Os periodos encontrados pelo programa Periodo (figura B) são os seguintes: um par siltito/folhelho = ciclo de 22 anos (Hale): dois pares = ciclo de 50 anos (duplo de Hale); ciclo de 150 a 180 anos (King Hele/Seuss) = em azul; ciclo de 650 a 1000 anos = em vermelho e laranja. Os dois últimos ciclos estão limitados pelas linhas tracejadas vermelhas. Os pares estão individualizados pelas linhas tracejadas pretas até a profundidade de 290,14 m, onde cada a distância entre dois picos representa um par (esquerda do gráfico). 


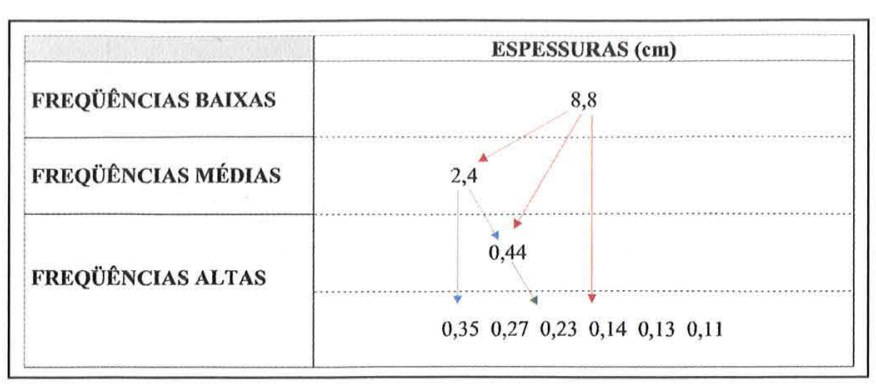

Figura 27 - Espessuras encontradas no intervalo de 290,23 a 290,46 m no gráfico de escala de cinza do poço 7-RL-04-SC, de acordo com o periodograma, e a relação entre elas.

\begin{tabular}{|c|c|c|c|c|c|c|c|c|c|c|}
\hline \multicolumn{11}{|c|}{ MATRIZ DE TEMPO } \\
\hline \multicolumn{11}{|c|}{ Título: MATRIZ DE MANCHAS SOLARES } \\
\hline \multicolumn{11}{|c|}{ Unidade: anos } \\
\hline & 1000 & 750 & 650 & 280 & 180 & 150 & 100 & 80 & 50 & 22 \\
\hline 1000 & 1 & 1,33 & 1,54 & 3,57 & 5,56 & 6,67 & 10 & 12,5 & 20 & 45,45 \\
\hline 750 & & 1 & 1,15 & 2,68 & 4,17 & 5 & 7,5 & 9,38 & 15 & 34,09 \\
\hline 650 & & & 1 & 2,32 & 3,61 & 4,33 & 6,5 & 8,13 & 13 & 29,55 \\
\hline 280 & & & & 1 & 1,56 & 1,87 & 2,8 & 3,5 & 5,6 & 12,73 \\
\hline 180 & & & & & 1 & 1,2 & 1,8 & 2,25 & 3,6 & 8,18 \\
\hline 150 & & & & & & 1 & 1,5 & 1,88 & 3 & 6,82 \\
\hline 100 & & & & & & & 1 & 1,25 & 2 & 4,55 \\
\hline 80 & & & & & & & & 1 & 1,6 & 3,64 \\
\hline 50 & & & & & & & & & 1 & 2,27 \\
\hline 22 & & & & & & & & & & 1 \\
\hline \multicolumn{11}{|c|}{ MATRIZ DE ESPESSURA } \\
\hline \multicolumn{11}{|c|}{ Título: Poço IB-93-RS - Prof.: 290,23 a $290,46 \mathrm{~m}$} \\
\hline \multicolumn{11}{|c|}{ Similaridade Trabalhada: $89 \%$ - Unidade: centímetros } \\
\hline & 8,8 & 2,4 & 0,44 & 0,35 & 0,27 & 0,23 & 0,18 & 0,14 & 0,13 & 0,11 \\
\hline 8,8 & 1 & 3,67 & 20 & 25,14 & 32,59 & 38,26 & 48,89 & 62,86 & 67,69 & 80 \\
\hline 2,4 & & 1 & 5,45 & 6,86 & 8,89 & 10,43 & 13,33 & 17,14 & 18,46 & 21,82 \\
\hline 0,44 & & & 1 & 1,26 & 1,63 & 1,91 & 2,44 & 3,14 & 3,38 & 4 \\
\hline 0,35 & & & & 1 & 1,3 & 1,52 & 1,94 & 2,5 & 2,69 & 3,18 \\
\hline 0,27 & & & & & 1 & 1,17 & 1,5 & 1,93 & 2,08 & 2,45 \\
\hline 0,23 & & & & & & 1 & 1,28 & 1,64 & 1,77 & 2,09 \\
\hline 0,18 & & & & & & & 1 & 1,29 & 1,38 & 1,64 \\
\hline 0,14 & & & & & & & & 1 & 1,08 & 1,27 \\
\hline 0,13 & & & & & & & & & 1 & 1,18 \\
\hline 0,11 & & & & & & & & & & 1 \\
\hline
\end{tabular}

Figura 28 - Matrizes de tempo e espessura do intervalo entre 290,46 a 290,23 m do gráfico de escala de cinza do poço IB93-RS.

folhelhos da base foram depositados em mais ou menos $150 \mathrm{mil}$ anos, os $32 \mathrm{~m}$ de ritmitos do interior da seção em aproximadamente 342 mil anos e os $48 \mathrm{~m}$ de folhelho superiores em cerca de 590 mil anos. Comparativamente, os folhelhos demoraram mais tempo para se depositar. Porém, as taxas de acumulação médias para esses intervalos são próximas $(8,0,9,4$ e $8,1 \mathrm{~cm} / \mathrm{ka}$, respectivamente), sugerindo que os folhelhos não são de águas muito profundas. Podem representar os equivalentes distais dos ritmitos, com apenas alguma contribuição hemipelágica. Essa interpretação já havia sido proposta por Machado (1989).

O poço IB-93-RS mostra uma variação muito rápida nas taxas de acumulação, devida ao rápido degelo e à posição mais proximal dos depósitos na época da sedimentação, relativamente ao poço anterior. Essa proximidade com a área fonte fez com que as taxas na porção basal do testemunho se apresentassem muito altas, chegando a várias dezenas de metros por mil anos, diminuindo progressivamente até se tornarem comparáveis às do poço 7-RL-04-SC no intervalo analisado. Isso impossibilitou
Tabela 9 - Espessuras e períodos correspondentes dos ciclos solares para o intervalo entre 290,46 a 290,08 m do testemunho do poço IB-93-RS.

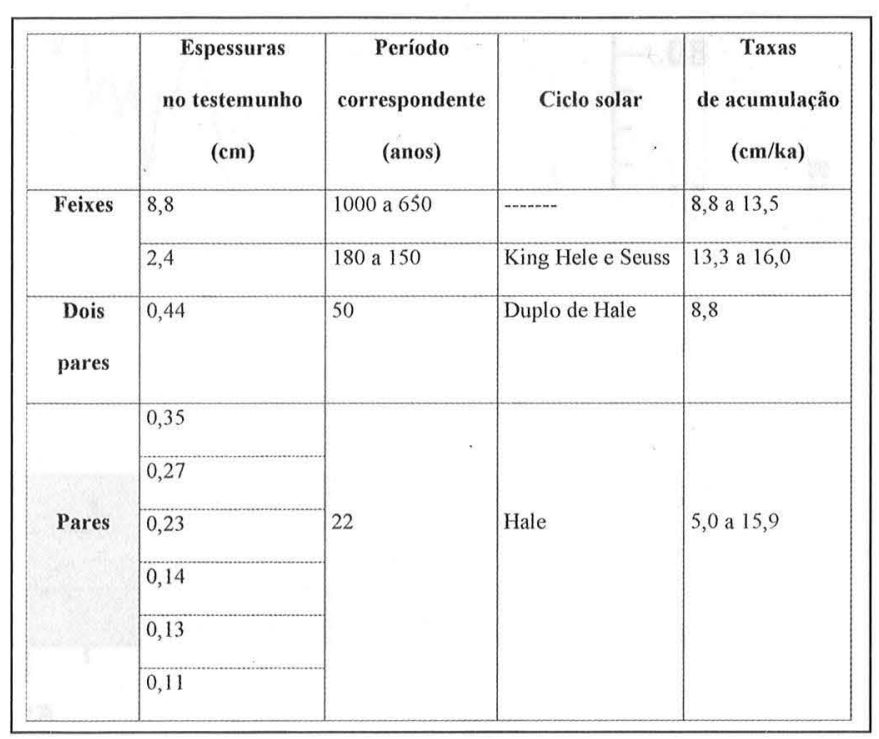

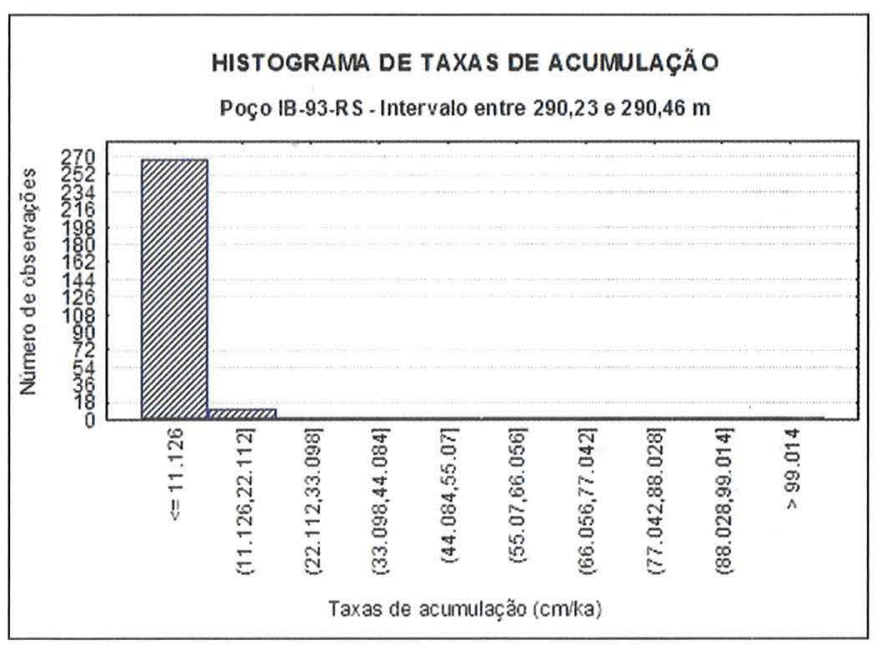

Figura 29 - Histograma das taxas de acumulação para o poço 7-RL-04-SC, no intervalo entre 290,23 e 290,46 m. As taxas mais freqüentes são as abaixo de $11,1 \mathrm{~cm} / \mathrm{ka}$.

a análise do perfil de raios gama. A taxa calculada para toda a seção até o primeiro folhelho $(3,6 \mathrm{~m} / \mathrm{ka})$, sendo uma média, é alta, pois no intervalo analisado a taxa é de cerca de $8,7 \mathrm{~cm} / \mathrm{ka}$, e. atesta a grande profusão de sedimentos jogados na bacia durante a rápida fusão das geleiras na escala dos ciclos orbitais.

A comparação entre o tempo total registrado nos dois poços é uma evidência da relatividade entre a espessura e o tempo envolvido na sedimentação de seqüências diferentes. Comparando seções diferentes, seções espessas podem representar intervalos de tempo pequenos e vice-versa, dependendo do contexto deposicional. Apesar da espessura total estudada do poço 7-RL04-SC ser de 99 m e do IB-93-RS de 44 m (de 334 até 290 m), o segundo possuindo cerca de $44 \%$ da espessura do primeiro, o tempo relativo a cada uma das seções é de aproximadamente 1.260.000 anos e 12.342 anos, respectivamente. Portanto, o segundo representa apenas cerca de $1 \%$ do tempo de deposição do primeiro. Seções de espessura equivalente ou comparável podem dar a impressão errada de conterem intervalos de tempo 


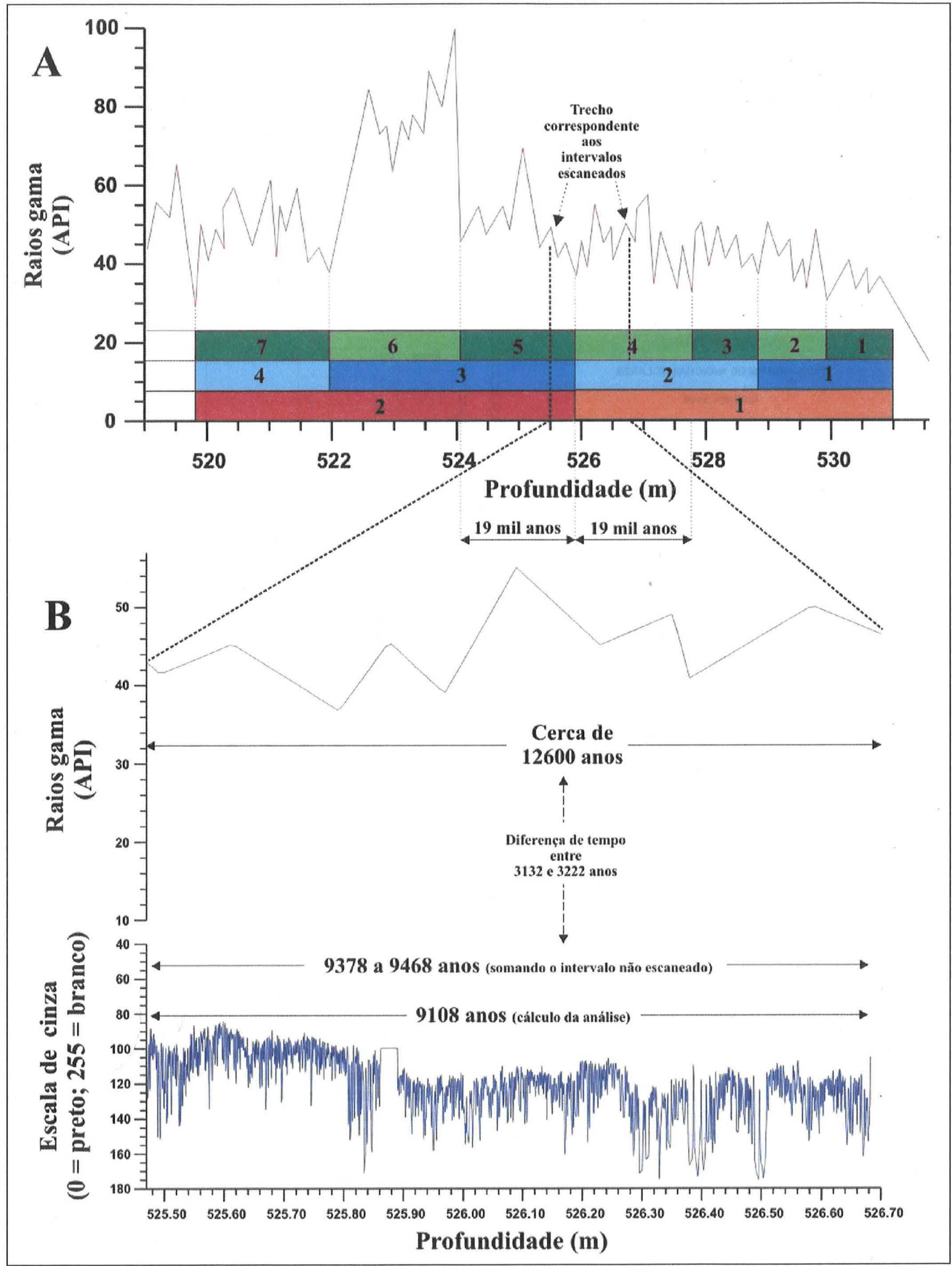

Figura 30 - Correlação temporal entre os dados do perfil de raios gama e do gráfico de escala de cinza para o poço 7-RL-04-SC. Os intervalos escaneados correspondem aproximadamente a 2/3 do tempo de um ciclo de precessão (cerca de 12600 anos), significando um hiato entre 3132 e 3222 anos. Na figura as profundidades estão deslocadas 5,98 m. 
semelhantes. Dependendo da ordem estratigráfica estudada, somente a cicloestratigrafia pode fornecer o nivel de detalhe requerido para a obtenção do tempo envolvido.

CORRELAÇÃO ENTRE AS ESCALAS ESTUDADAS A metodologia utilizada para a análise é uma ferramenta importante de detalhamento estratigráfico. Quando comparamos as duas escalas de investigação, perfil (ciclos orbitais) e testemunho (ciclos solares), de forma a conferir as durações em tempo obtidas no poço 7-RL-04-SC, os resultados são bastante satisfatórios (figura 30).

É preciso lembrar que as profundidades mostradas na figura não são as originais, mas as corrigidas após a retirada das camadas de diabásio. As profundidades dos testemunhos também tiveram que ser deslocadas $5,98 \mathrm{~m}$ para a correlação (detalhes no artigo CEGI-1, nesta publicação).

O tempo total visualizado no gráfico de escala de cinza foi estimado entre 9378 e 9468 anos. A correlação com o perfil de raios gama revela que esse representa aproximadamente dois terços de um ciclo de precessão. Lembrando que o período médio da precessão no Eopermiano era de cerca de 19 mil anos, dois terços são aproximadamente 12600 anos, o que nos leva a uma diferença entre 3132 e 3222 anos. A ordem dos valores é a mesma e, considerando as aproximações intrínsecas aos dois métodos de análise (testemunhos e perfis) e o fato de que os períodos utilizados dos ciclos solares e orbitais são valores médios encontrados na literatura, os resultados comprovam a utilidade da metodologia adotada e validam a alta resolução alcançada na medição dos intervalos de tempo de deposição dos sedimentos.

A diferença (3132 a 3222 anos) pode ser interpretada tentativamente como hiato na deposição, se não contarmos a possibilidade de ciclos de precessão mais curtos que os de 17600 anos (menor média, Berger \& Loutre 1994), de ciclos solares de Hale da ordem de 26 anos (ao invés da média de 22 anos, tabela III.4), ou a ocorrência simultânea de ambos. Sendo a espessura média dos ciclos de Hale nos gráficos de escala de cinza da ordem de 3 $\mathrm{mm}$, o hiato representaria cerca de $40 \mathrm{~cm}$. O tempo equivalente a essa espessura poderia estar distribuído ao longo do ciclo de precessão em intervalos pequenos, representados por períodos de não deposição ou por pequenas erosões na base das lâminas de siltito, que removeriam pares anteriores. Uma outra possibilidade seria que o rejeito da pequena falha fosse maior.

COMENTÁRIOS FINAIS Os mecanismos de indução climática estudados, orbitais e solares, pertencem a ordens diferentes. As variações no padrão de sedimentação e na taxa de acumulação, nas escalas dos ciclos solares e orbitais, obedecem às induções na alta e na baixa freqüência, respectivamente. Porém, existe uma tendência à modulação dos feixes observados nos testemunhos pelas mudanças no aporte sedimentar na baixa freqüência. Isso pode ser observado no gráfico de escala de cinza e na curva do perfil de raios gama (figura 31). Essa modulação mostra o acoplamento do sistema climático como um todo e da resposta na sedimentação, que varia e oscila de forma conjunta em direção aos membros finais de máximo e mínimo climáticos de baixa freqüência. Porém, essas oscilações e variações ocorrem em diferentes ordens temporais, de forma que mesmo climas muito quentes podem experimentar períodos de frio relativo de mais alta freqüência, enquanto que climas muito frios são passíveis de coexistir com épocas de aquecimento de ordem maior. Um exemplo é o atual período interglacial, onde flutuações nos padrões climáticos, como o El Niño, podem causar aquecimento em várias regiões do planeta. Outros exemplos são as pequenas eras do gelo, ligadas aos ciclos solares, as quais provocaram frios intensos e invernos rigorosos em vários pontos do planeta. Sendo assim, os desvios do perfil de raios gama para valores menores, denotando aumentos na granulometria fora dos máximos glaciais, podem significar essas oscilações de alta freqüência no clima, relacionadas à indução dos ciclos solares (figura 31).

Os resultados obtidos na análise mostraram que as periodicidades ligadas aos ciclos solares estão ligadas aos pares individuais de camadas ou lâminas, as menores unidades cicloestratigráficas observáveis no registro sedimentar dos testemunhos. Logo, o menor tempo registrado nas rochas eqüivale a 22 anos, aproximadamente. Talvez seja difícil imaginar que eventos de menor freqüência, como os ciclos anuais (varves), freqüentemente encontrados em depósitos associados a geleiras, não tenham deixado suas marcas. $\mathrm{O}$ ambiente, sendo relativamente profundo e distal, poderia explicar a inexistência desses registros. Mas varvitos, de origem glacial ou não, também são observados em sedimentos marinhos (Anderson 1961, Domack 1984, Mackiewicz et al. 1984, Von Rad et al. 1999), sendo formados por fluxos de turbidez de baixa densidade, assim como os sedimentos estudados nos dois poços. Porém, o registro sedimentar não é linear ou preditivo. De alguma forma, somente alguns eventos ou ciclos são preservados.

Entre o tempo de deposição dos perioditos ligados aos ciclos solares e aquele dos varvitos existe pelo menos uma ordem de grandeza, sendo que certos registros sedimentares, em diferentes regiões do planeta, mostram ambas as periodicidades preservadas em uma mesma seqüência (Anderson 1961, Ripepe et al. 1991, Anderson 1992, Von Rad et al. 1999). Varvitos glaciais são, normalmente, formados por pares de lâminas milimétricas a submilimétricas (Domack 1984, Von Rad et al. 1999), podendo alcançar até algumas dezenas de centímetros de espessura próximo a regiões deltaicas (Reineck \& Singh 1980, Talbot \& Allen 1996), e preservam-se em ambientes calmos, sem muita energia (Reineck \& Singh 1980 Von Rad et al. 1999), pois, de outra forma, seus depósitos caracteristicamente finos sofreriam retrabalhamento por ondas ou correntes. Os pares estudados nos dois testemunhos, apesar de possuírem espessuras médias da ordem de milímetros, podem chegar até a vários metros, como é o caso do poço IB-93RS. Logo, é possível que a intensidade dos processos sedimentares que geraram os fluxos periódicos, responsáveis pela deposição dos pares de ritmos, obliterassem eventualmente outros depósitos de maior freqüência, por causa de parâmetros como maior energia e maior densidade ou carga sedimentar.

Por outro lado, se varvitos foram originalmente depositados, deveriam estar presentes intercalados nas lâminas de folhelho na forma de pares menos espessos que aqueles que estão hoje no registro sedimentar. Ou seja, os pares relacionados à ciclicidade solar, que foram caracterizados nesse estudo, representariam um ano dos vinte e dois necessários para completar o ciclo. Como os varvitos não foram observados, nem nas lâminas petrográficas, o mais provável é que não chegaram a ser depositados. A influência do ambiente marinho, com suas taxas de acumulação caracteristicamente menores que as do ambiente lacustre, pode também ter contribuído para sua ausência.

Os resultados obtidos não invalidam a existência de varvitos em outros pontos da bacia, mas sugerem que, nos pontos onde esses estejam presentes, ocorra também a ritmicidade ligada aos ciclos solares, como tem sido demonstrado em outras bacias no mundo.

As alternâncias climáticas sugeridas pelo registro sedimentar visualizado hoje nas rochas do Grupo Itararé simbolizam o final da denominada Glaciação Neopaleozóica, que se deu à medida que o continente Gonduana se posicionava em latitudes menores (Milani, 1997). O recuo gradual das geleiras é evidenciado pela passagem das fácies glaciais para outras representativas de climas mais amenos, representadas pelas rochas da Formação 


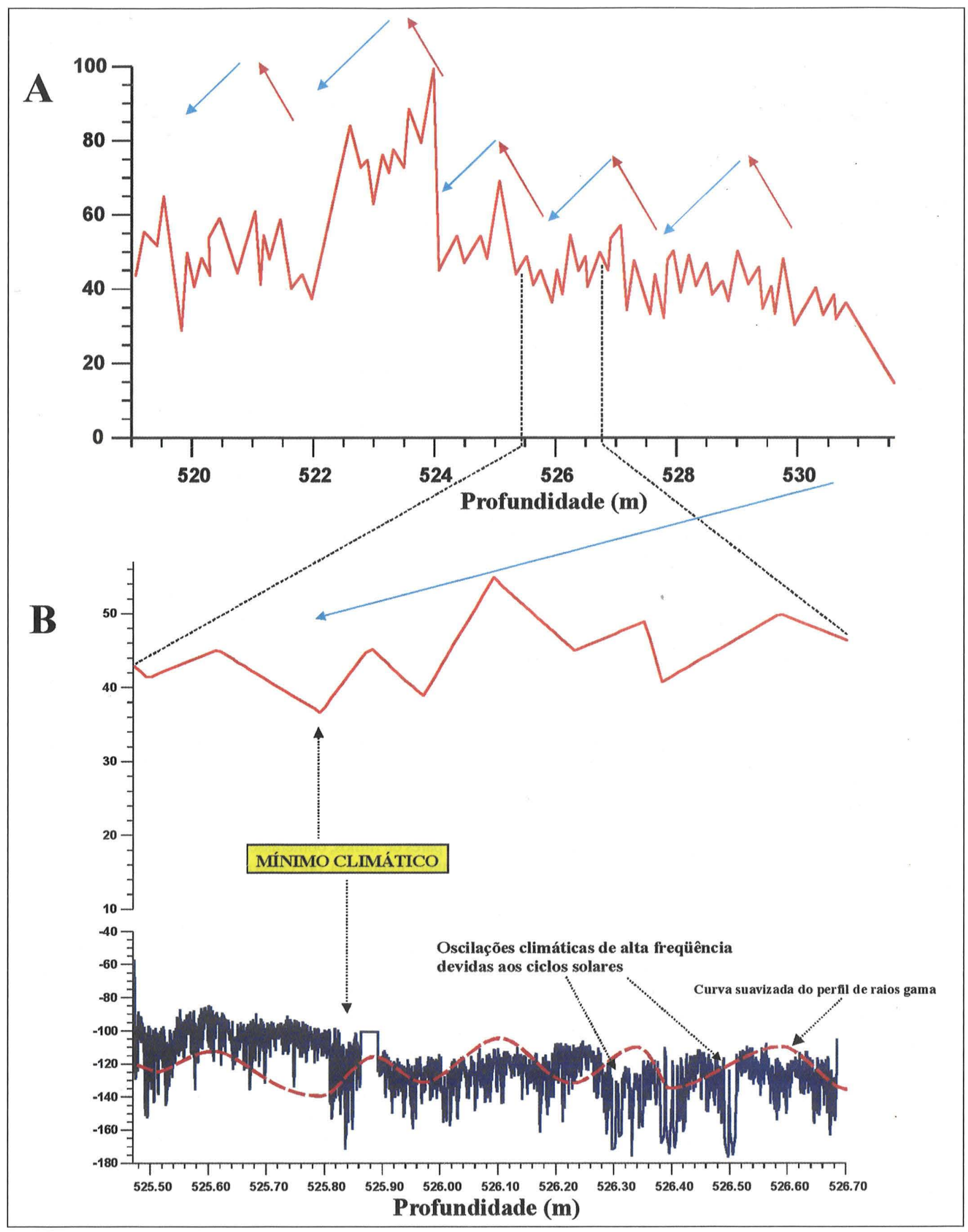

Figura 31 - A - perfil de raios gama; B - correlação entre o gráfico de escala de cinza e o perfil de raios gama. Setas vermelhas e azuis marcam, respectivamente, tendências aos máximos e mínimos climáticos dos ciclos de precesisão. Na figura B está representada a tendência ao mínimo climático do ciclo de precessão número 4 (figura 30). Notar correspondência entre este e um aumento no aporte sedimentar no gráfico de escala de cinza. Curva vermelha tracejada: curva suavizada do perfil de raios. Trechos na figura B que mostram alto aporte sedimentar e que não coincidem com mínimo climático representam oscilações devidas aos ciclos solares de baixa freqüência. 
Rio Bonito, depositadas acima da seqüência estudada. Essa interpretação é antiga, tendo sido feita por vários autores, inclusive por Machado (1994), o qual reconhece igualmente que "o grau de resolução que os testemunhos e perfis fornecem pode nos levar à identificação de ciclos de alta freqüência, propiciando a descoberta de rápidos pulsos glaciais dentro do degelo final". Os ciclos orbitais de excentricidade identificados devem representar os pulsos referidos por Machado (1994), significando pequenos avanços e recuos glaciais de alta freqüência dentro do grande ciclo de degelo da bacia. A correlação dos ciclos orbitais encontrados nos perfis com a estratigrafia de seqüências e os ambientes de sedimentação será objeto de outro artigo, em futuro próximo.

Finalizando, pode-se identificar dois fenômenos de indução climática, ambos ligados às interações entre a Terra e o Sol. Por serem fenômenos que afetam o clima de maneira global, certa- mente influenciaram a sedimentação em outros pontos da Bacia do Paraná. Sendo assim, estudos futuros que venham a detectar essa ciclicidade em localidades diferentes da bacia podem levar a uma resolução temporal muito detalhada e maior que a atual divisão cronoestratigráfica existente.

Agradecimentos À PETROBRAS pela oportunidade de fazer este estudo. À CPRM pela cessão dos dados de poços e suas descrições. Ao Prof. Dr. Luis Fernando De Ros pelo auxílio na descrição das lâminas petrográficas. Aos colegas da pós-gradụação da UFRGS, pela descrição em conjunto do testemunho do poço 7-RL-04-SC. Ao colega Saulo Ferreira Santos, pelos originais de sua descrição desse testemunho e pelas discussões sobre o mesmo. E à colega Ariane da Silveira, pelas discussões e colaboração durante a descrição do testemunho do poço IB-93-RS, no campus da UNISINOS.

\section{Referências}

Anderson, Roger Y. 1961. Solar-terrestrial climatic patterns in varved sediments. Annals of the New York Academy of Sciences, v.95, p. 424-439.

Anderson, Roger Y. 1963. Harmonic analysis of varve time series Journal of Geophysical Research, v.68, n.3, p. 877-893, January.

Anderson, Roger Y. 1992. Possible connection between surface winds, solar activity and the Earth's magnetic field. Nature, v.358, p. 5153 , July.

Algeo, Thomas J. \& Wilkinson, Bruce H. 1988. Periodicity of mesoscale Phanerozoic sedimentary cycles and the role of Milankovitch orbital modulation. The Journal of Geology, v.96, p. 313-322.

Azambuja Filho, Nilo Chagas de. 1990. The Oligo-Miocene turbidites and associated facies of the Campos Basin, offshore Brazil. London, United Kingdom. 456p. PhD Thesis, University of London.

Berger, André \& Loutre, M. F. 1989. Pre-Quaternary Milankovitch frequencies. Nature, v.342, p. 133, November.

Berger, André \& Loutre, M. F. 1994. Astronomical forcing through geological time. In: De Boer, P. L. \& Smith, D. G. (ed.). 1994. Orbital forcing and cyclic sequences. Oxford: Blackwell Scientific Publications. p. 15-24. (International Association of Sedimentologists Special Publication, 19).

Bucha, Václav. 1988. Influence of solar activity on atmospheric circulation types. Annales Geophysicae, v.6, n.5, p. 513-524.

Bucha, Václav. 1991. Solar and geomagnetic variability and changes of weather and climate. Journal of Atmospheric and Terrestrial Physics, v.53, n.11/12, p. 1161-1172.

Bucha, Václav \& Bucha Jr., Václav. 1998. Geomagnetic forcing of changes in climate and in the atmospheric circulation. Journal of Atmospheric and Solar-Terrestrial Physics, v.60, n.2, p. 145-169.

Canuto, José Roberto. 1993. Facies e ambientes de sedimentação da Formação Rio do Sul (Permiano), Bacia do Paraná, na região de Rio do Sul, Estado de Santa Catarina. São Paulo, 164p. Tese de Doutorado em Geociências, Instituto de Geociências, Universidade de São Paulo.

Castro, Joel Carneiro de. 1980. Fácies, ambientes e seqüências deposicionais das formações Rio do Sul e Rio Bonito, leste de Santa Catarina. In: Cong. Brás. Geol., 31., Balneário de Camburiu, 1980. Anais... Balneário de Camburiu: SBG., v.1, p. 283-299.
Castro, Joel Carneiro de. 1991. A evolução dos sistemas glacial, marinho e deltaico das formações Rio do Sul e Rio Bonito/Mb. Triunfo (Eopermiano), sudeste da Bacia do Paraná. Rio Claro, $147 \mathrm{p}$. Tese de Doutorado em Geociências, Instituto de Geociências e Ciências Exatas, Universidade Estadual Paulista.

Castro, Joel Carneiro de. 1995. Ciclos ou seqüências no arcabouço cronoestratigráfico da sucessão Itararé (Formação Taciba) - Rio Bonito (Membro Triunfo), Bacia do Paraná. In: Simpósio Sobre Cronoestratigrafia da Bacia do Paraná, 2, Porto Alegre. Boletim de Resumos Expandidos, p. 66-70.

Castro, Joel Carneiro de \& Schneider, Ruben L. 1993. Cronoestratigrafia e evolução paleogeográfica da sucessão Itararé-Rio Bonito (Membro Triunfo), SE da Bacia do Paraná. In: Simp. Cronoest. da Bacia do Paraná, 1, Rio Claro. Boletim de Resumos, p. 37-38.

Cazzulo-Klepzig, Miriam; Guerra-Sommer, Margot \& Marques-Toigo, Marleni. 1980. Estudo macro e microflorístico do Grupo Itararé (Bacia do Paraná), Rio Grande do Sul. In: Cong. Bras. Geol, 31. Balneário de Camboriú, 1980. Anais... Balneário de Camboriú: SBG., v.5, p. 3027-3040.

Chatfield, C. 1989. The analysis of time series - an introduction. London: Chapman and Hall. $241 \mathrm{p}$

Chaves, Hernani A. F.; Della Favera, Jorge C.; Medeiros, Marco A. M \& Pereira, Silvia Dias. 1994. Eventos cíclicos no Permiano das áreas de Candiota (RS) e Figueira-Sapopema (PR), Bacia do Paraná. In: Cong. Bras. Geol., 38., Balneário de Camburiu, 1994. Boletim de Resumos. Balneário de Camburiu: SBG., v.1, p. 594-595.

Chaves, Hernani A. F.; Della Favera, Jorge C.; Medeiros, Marco A. M.; Pereira, Silvia Dias \& Rodrigues, Telmo Luiz das Neves. 1995. Sedimentação cíclica na seção permiana da Bacia do Paraná, áreas de Figueira-Sapopema (PR), distrito carbonífero de Santa Catarina e Candiota (RS). In: Simp. Cronoest. da Bacia do Paraná, 2., Porto Alegre, 1995. Boletim de Resumos Expandidos. Porto Alegre: UFRGS., p. 106-110.

Cottle, R. A. 1989. Orbitally mediated cycles from the Turonian of southern England: their potential for high-resolution stratigraphic correlation. Terra Nova, v.1, n. 5, p. 426-436.

Crowley, Thomas J. \& North, Gerald R. 1991. Paleoclimatology. New York: Oxford University Press. (Oxford Monographs on Geology and Geophysics, 18). 339 p.

Daemon, Roberto Ferreira \& Quadros, Luis Padilha de. 1970. 
Bioestratigrafia do Neopaleozóico da Bacia do Paraná. In: SBG, Cong. Brás. Geol., 24., Brasília,. Anais, p. 359-412.

Damon, Paul E. \& Linick, Timothy W. 1986. Geomagneticheliomagnetic modulation of atmospheric radiocarbon production. Radiocarbon, v. 28, n.2A, p. $266-278$.

De Boer, P. L. \& Smith, D. G. 1994. Orbital forcing and cyclic sequences. In: De Boer, P. L. \& Smith, D. G. (ed.). 1994. Orbital forcing and cyclic sequences. Oxford: Blackwell Scientific Publications. p. 1-14. (International Association of Sedimentologists Special Publication, 19).

Dias, Maria Elice Rosa. 1993a. Palinologia do Gmpo Itararé no Rio Grande do Sul. Porto Alegre, 227p. Tese de Doutorado em Geociências, Instituto de Geociências, Universidade Federal do Rio Grande do Sul.

Dias, Maria Elice Rosa. 1993b. Palinologia do Grupo Itararé no Rio Grande do Sul, Permiano da Bacia do Paraná, Brasil. In: Cong. Brás. Paleo., 13., São Leopoldo, 1993. Boletim de Resumos. São Leopoldo: CPRM, p. 63.

Dias, Maria Elice Rosa. 1993c. Associações microflorísticas dos paleovales do Grupo Itararé no Rio Grande do Sul, Permiano da Bacia do Paraná, Brasil. Pesquisas, v.20, n. 2, p. 132-140.

Dicke, R. H. 1979. Solar luminosity and the sunspot cycle. Nature, v. 280 , p. 24-27, July.

Domack, E. W. 1984. Rhythmically bedded glaciomarine sediments on Whidbey Island, Washington. Journal of Sedimentary Petrology, v. 54, n. 2 , p. 589-602, June.

Eddy, John A. 1976. The Maunder Minimum. Science, v.192, p. 1189. 1202, June.

Einsele, Gerhard; Ricken, Werner \& Seilacher, Adolf. 1991. Cycles and events in stratigraphy - basic concepts and terms. In: Einsele, Gerhard; Ricken, Werner \& Seilacher, Adolf. (ed.). 1991. Cycles and events in stratigraphy. Berlin: Springer-Verlag. p. 1-19.

Elverhфi, Anders \& Henrich, R. 1996. Glaciomarine environments 'Ancient glaciomarine sediments'. In: Menzies, John. (ed.) 1996. Past glacial environments: sediments, forms and techniques. Volume 2. Oxford: Butterworth-Heinemann Ltd. p. 179-211.

Fischer, A. G. \& Roberts, L. T. 1991. Cyclicity in the Green River Formation (lacustrine Eocene) of Wyoming. Journal of Sedimentary Petrology, v.61, n. 7, p. 1146-1154, December.

Fortes, Fernando Parentes. 1990. As manchas solares e o passo das dunas. PETROBRAS/DENOR/DINTER. Relatório interno, $50 \mathrm{p}$.

Fortes, Fernando Parentes. 1992. As manchas solares e o passo das dunas. In: Cong. Bras. Geol., 37., São Paulo, 1992. Boletim de Resumos Expandidos. São Paulo: SBG., v.1, p. 297-298.

França, Almério Barros. \& Potter, Paul E. 1988. Estratigrafia, ambiente deposicional e análise de reservatório do Grupo Itararé (Permocarbonifero), Bacia do Paraná (parte 1). Boletim de Geociências da Petrobras, v.2, n. 2/4, p. 147-191, abril/dezembro.

Gallet, Yves; Genevey, Agnès \& Fluteau, Frédéric. 2005. Does Earth's magnetic field secular variation control centennial climate change? Earth and Planetary Science Letters, n.236, p. 339-347.

Glenn, C. R. \& Kelts, K. 1991. Sedimentary rhythms in lake deposits. In: Einsele, Gerhard; Ricken, Werner \& Seilacher, Adolf. (ed.). 1991. Cycles and events in stratigraphy. Berlin: Springer-Verlag. p. $188-221$.
Guerra-Sommer, Margot \& Cazzulo-Klepzig, Miriam. 1993. Biostratigraphy of the Southern Brazilian Neopaleozoic Gondwana Sequence: a preliminary palaeobotanical approach. In: Congrès International de la Stratigraphie et Géologie du Carbonifère et Permian, 12. Buenos Aires, 1993. Compte Rendu... Buenos Aires, v. 2, p. $61-72$.

Halfman, John D. \& Johnson, Thomas C. 1988. High-resolution record of cyclic climatic change during the past $4 \mathrm{ka}$ from Lake Turkana, Kenya. Geology, v.16, p. 496-500, June.

Harbaugh, John W. \& Merriam, Daniel F. 1968. Computer applications in stratigraphic analysis. New York: John Wiley \& Sons, Inc. 282 p.

Hays, J. D.; Imbrie, John \& Shackleton, N. J. 1976. Variations in the Earth's orbit: pacemaker of the ice ages. Science, v.194, p. 11211132, December.

Heinrich, Hartmut. 1988. Origin and consequences of cyclic ice rafting in the Northeast Atlantic Ocean during the past 130,000 years. Quaternary Research, v.29, p. 142-152.

Holz, Michael. 1995a. O intervalo gonduânico basal (Eo-Permiano) da Bacia do Paraná na região nordeste do Rio Grande do Sul - um exercício de estratigrafia. Porto Alegre, 256 p., 2 volumes. Tese de Doutorado em Geociências, Instituto de Geociências, Universidade Federal do Rio Grande do Sul.

Holz, Michael. 1995b. Proposta de arcabouço cronoestratigráfico de terceira ordem para o pacote eo-permiano da Bacia do Paraná no Rio Grande do Sulı. In: Simp. Cronoestrat. Bacia do Paraná, 2., Porto Alegre, 1995. Boletim de Resumos Expandidos. Porto Alegre: UFRGS., p. 91-97.

House, Michael R., 1995. Orbital forcing timescales: an introduction. In: House, Michael, R. \& Gale, A. S. (ed.). 1995. Orbital forcing timescales and cyclostratigraphy. London: The Geological Society, p. 1-18.

Hoyt, Douglas, V. \& Schatten, Kenneth H. 1997. The role of the Sun in climate change. New York: Oxford University Press. 279 p.

Imbrie, John \& Imbrie, John Z. 1980. Modeling the climatic response to orbital variations. Science, v.207, p. 943-953, February.

Jaminski, J.; Algeo, T.; Maynard, B. \& Hower, J. C. 1998. Climatic origin of dm-scale compositional cyclicity in the Cleveland Member of the Ohio Shale (Upper Devonian), Central Appalachian Basin U.S.A. In: Schieber, J. (ed.). 1998. Recent progress in shale research. New York: Schweizerbart'sche. p. 217-242.

Ji, Jinjun; Petit-Maire, Nicole \& Yan, Zhongwei. 1993. The last 1000 years: climatic change in arid Asia and Africa. Global and Planetary Change, Amsterdam, v.7, p. 203-210.

Johnsen, S. J.; Dansgaard, W. \& Clausen, H. B. 1970. Climatic oscilations 1200-2000 AD. Nature, v.227, p. 482-483, August.

Kukal, Zdenek. 1990. The rate of sedimentation. In: Kukal, Zdenek. (ed.). 1990. The rate of geological processes. Earth-Science Reviews, Amsterdam, v.28, n.1, 2, 3, p. 94-133, July. (Special Issue).

Labitske, Karin. 1987. Sunspot, the QBO, and the stratospheric temperature in the north polar region. Geophysical Research Letters, v.14, n.5, p. 535-537, May.

Linacre, Edward \& Geerts, Bart. 1997. Climates and weather explained. London: Routledge. $432 \mathrm{p}$

Lopes, Ricardo da Cunha. 1995. Arcabouço aloestratigráfico para o intervalo "Rio Bonito-Palermo" (Eopermiano da Bacia do Paraná), entre Butiá e São Sepé, Rio Grande do Sul. Porto Alegre, 
254p. Dissertação de Mestrado em Geociências, Centro de Ciências Tecnológicas, Universidade do Vale do Rio dos Sinos.

Lopes, Ricardo da Cunha; Holz, Michael; Piccoli, A. E. M.; DiasFabricio, Maria E.; Cazzulo-Klepzig, Miriam.; Marques-Toigo, Marleni \& Guerra-Sommer, Margot. 1991. Stratigraphical revision of the Itarare Group (Lower Permian), Parana Basin, southern Brazil. In: Intern. Cong. Carboniferous and Permian Geol. Strat., 12., Buenos Aires, 1991. Abstracts. Buenos Aires.

Lundqvist, Jan. 1998. Periodical sedimentation in scandinavian eskers. In: Intern. Conf. Recognition Abrupt Climate Change in Clastic Sedim. Environ.: Methods, Limitations and Potential. Stockholm, 1998. Program and Abstracts. Stockholm, sem paginação.

Machado, Luís Cláudio Ribeiro. 1989. Fácies e arcabouço estratigráfico do Grupo Itararé em Alfredo Wagner (SC) - Sedimentação periglacial. Ouro Preto, 164p. Dissertação de Mestrado em Geociências, Departamento de Geologia, Universidade Federal de Ouro Preto.

Machado, Marco Antônio Pinheiro. 1994. O degelo final permiano e o seu registro geológico na borda sudeste da Bacia do Paraná (Paleovale de Candiota - RS). Porto Alegre, 165p. Dissertação de Mestrado em Geociências, Instituto de Geociências, Universidade Federal do Rio Grande do Sul.

Mackiewicz, N. E.; Powell, R. D.; Carlson, P. R. \& Molnia, B. F. 1984. Interlaminated ice-proximal glacimarine sediments in Muir Inlet, Alaska. Marine Geology, Amsterdam, v.57, p. 113-147.

Marques-Toigo, Marleni. 1991. Palynobiostratigraphy of the Southern Brazilian Neopalaeozoic Gondwana Sequence. In: ULBRICH, $\mathrm{H}$. \& ROCHA CAMPOS, A. C. (ed.). 1991. GONDWANA SEVEN., São Paulo, 1991. Proceedings. São Paulo: Instituto de Geociências da Universidade de São Paulo., p. 503-515.

Marques-Toigo, Marleni; Dias-Fabrício, Maria E.; Guerra-Sommer, Margot; Cazzulo-Klepzig, Miriam. \& Piccoli, A. E. M. 1989. Afloramentos da área de Trombudo Central, Permiano inferior, Santa Catarina: palinologia, icnologia e sedimentologia. In: SBP, Cong. Bras. Paleo., 11, Curitiba. Anais, v.1, p. 125-150.

Miller, Robert L. \& Kahn, James Steven. 1962. Statistical analysis in the geological sciences. New York: John Wiley \& Sons. 483p.

Reineck, H.-E. \& Singh, I. B. 1980. Depositional sedimentary environments. Würzburg: Springer-Verlag. p. 127-128, 201.

Ricken, W. 1993. Relative time span assessment. In: Richen, W. Sedimentation as a three-component system - organic carbon, carbonate, noncarbonate. Germany: Springer-Verlag. p. 47-55. (Lectures Notes in Earth Sciences).

Ripepe, M; Roberts, L. T. \& Fischer, A. G. 1991. Enso and sunspot cycles in varved Eocene oil shale from image analyses. Journal of Sedimentary Petrology, v.61, n. 7, p. 1155-1163, December.

Ross, Charles A.; Baud, Aymon \& Memming, Manfred. 1994. A time scale for project Pangea. In: Embry, A. F.; Beauchamp, B. \& Glass, D. J. (ed.). 1994. Pangea: global envionments and resources. Calgary: Canadian Society of Petroleum Geologists. p. 1-47. (Canadian Society of Petroleum Geologists Memoir, 17). p. 81-83.

Santos, P. R. dos; Rocha-Campos, A. C. \& Canuto, J. R. 1996. Patterns of late Paleozoic deglaciation in the Paraná Basin, Brazil. Palaeogeography, Palaeoclimatology, Palaeoecology, Amsterdam, v.125, p. $165-184$.

Schaaf, Michael \& Thurow, Jürgen. 1994. A fast and easy method to derive highest-resolution time-series datasets from drillcores and rock samples. Sedimentary Geology, v.94, p. 1-10.
Schaaf, Michael \& Thurow, Jürgen, 1997. Tracing short cycles in long records: the study of inter-annual to inter-centennial climate change from long sediment records, examples from the Santa Barbara Basin. Journal of the Geological Society, v.154, p. 613622, London.

Schwarzacher, W. 1975. Sedimentation models and quantitative stratigraphy. Amsterdam: Elsevier. (Developments in Sedimentology, 19). $382 \mathrm{p}$.

Schwarzacher, W. 1987. The analysis and interpretation of stratification cycles. Paleoceanography, v.2, n. 1, p. 79-95, February.

Schwarzacher, W. 1989. Milankovitch cycles and the measurement of time. Terra Nova, v.1, n. 5, p. 405-408.

Silva, José Guilherme Rodrigues da. 2001. Estudo de cicloestratigrafia nos depósitos eopermianos do Grupo Itararé, Bacia do Paraná nos estados de Santa Catarina e do Rio Grande do Sul, baseado em dados de testemunho e de perfis de raios gama. Porto Alegre, 228p. Dissertação de Mestrado em Geociências, Instituto de Geociências, Universidade Federal do Rio Grande do Sul.

Silveira, Ariane Santos da. 2000. Estratigrafia de seqüências e evoluçâo peleoambiental da sucessão permiana (Sakmariano-Eokazamiano) da Bacia do Paraná, entre Rio Pardo e Mariana Pimentel. Porto Alegre, 131p. Dissertação de Mestrado em Geociências, Centro de Ciências Exatas e Tecnológicas, Universidade do Vale do Rio dos Sinos.

Sonett, C. P. \& Suess, H. E. 1984. Correlation of bristlecone pine ring widths with atmospheric ${ }^{14} \mathrm{C}$ variations: a climate-Sun relation. Nature, v.307, p. 141-143, January.

Stuiver, Minze \& Braziunas, Thomas F. 1989. Atmospheric ${ }^{14} \mathrm{C}$ and century-scale solar oscillations. Nature, v.338, p. 405-408, March.

Stuiver, Minze; Grootes, Pieter M. \& Braziunas, Thomas F. 1.995. The GISP $\delta^{18} \mathrm{O}$ climate record of the past 16,500 years and the role of the sun, ocean, and volcanoes. Quaternary Research, v.44, p. 341-354.

Stuiver, M.; Braziunas, T. F.; Grootes, P. M. \& Zielinski, G. A. 1997. Is there evidence for solar forcing of climate in the GISP2 oxygen isotope record? Quaternary Research, v.48, p. 259-266.

Talbot, M. R. \& Allen, P. A. 1996. Lakes. In: Reading, H. G. (ed.). 1996. Sedimentary environments: processes, facies and stratigraphy. Cambridge: Blackwell Science Ltd., p. 83-124.

Tomazelli, Luiz José \& Soliani Jr., Enio. 1982. Evidências de atividade glacial no Paleozóico Superior do Rio Grande do Sul, Brasil. In: Cong. Bras. Geol., 32., Salvador, 1982. Anais... Salvador: SBG., v.4, p. $1378-1391$.

Von Rad, Ulrich; Schaaf, Michael; Michels, Klaus H.; Schulz, Hartmut; Berger, Wolfgang H. \& Sirocko, Frank. 1999. A 5000-yr record of climate change in varved sediments from the oxygen minimum zone off Pakistan, Northeastern Arabian Sea. Quaternary Research, v. 51, p. $39-53$

Weedon, G. P. 1991. The spectral analysis of stratigraphic time series. In: Einsele, Gerhard; Werner, Ricken \& Seilacher, Adolf. (ed.). 1991. Cycles and events in stratigraphy. Berlin: Springer-Verlag. p. $840-854$.

Williams, G. E. 1985. Solar affinity of sedimentary cycles in the late Precambrian Elatina Formation. Aust. J. Phys., v.38, p. $1027-$ 1043.

Williams, G. E. 1989. Late Precambrian tidal rhythmites in South 
Cicloestratigrafia do Eopermiano - estudo de caso no grupo Itararé, bacia do Paraná (Parte 2): evidências de indução astronômica (orbital e solar) no clima e na sedimentação

Australia and the history of the Earth's rotation. Journal of the Geological Society, v.146, p. 97-111, London.

Williams, G. E. \& Sonett, C. P. 1985. Solar signature in sedimentary cycles from the late Precambrian Elatina Formation, Australia. Nature, v.318, p. 523-527, July.
Yiou, P.; Fuhrer, K.; Meeker, L. D.; Jouzel, J.; Johnsen, S. \& Mayewski, P. A. 1997. Paleoclimatic variability inferred from the spectral analysis of Greenland and Antarctic ice-core data. Journal of Geophysical Research, v.102, n.C12, p. 26441-26454, November. 